Energy Systems Environmental Restoration Program

\title{
Lifecycle Baseline Summary for ADS 6504IS \\ Isotopes Facilities Deactivation Project at \\ Oak Ridge National Laboratory, \\ Oak Ridge, Tennessee
}

Date Issued-August 1995

Prepared by

Isotopes Facilities Deactivation Project

Environmental Restoration Divison

Oak Ridge National Laboratory

Prepared for

U.S. Department of Energy

Office of Environmental Management

under budget and reporting code EW 20

Environmental Restoration and Waste Management Programs

Oak Ridge National Laboratory

Oak Ridge, Tennessee 37831-6285

managed by

LOCKHEED MARTIN ENERGY SYSTEMS

for the

U.S. DEPARTMENT OF ENERGY

under contract DE-AC05-84OR21400

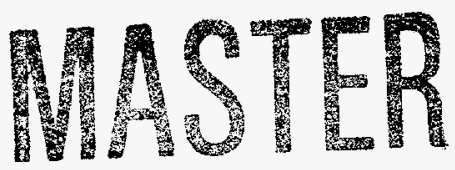

DISTRIBUTION OF THIS DOCUMENT IS UNLIMITED

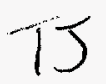




\section{DISCLAIMER}

Portions of this document may be illegible in electronic image products. Images are produced from the best available original document. 


\section{PREFACE}

This baseline plan was prepared to establish a technical, cost, and schedule baseline for the deactivation of various facilities on the Oak Ridge Reservation that, in the past, have been used to prepare radioactive isotopes. This element of work is not part of the Comprehensive Environmental Response Compensation and Liability Act, although it is being accomplished in accordance with the substantive requirements of the act. This project is listed under Work Breakdown Structure 1.6.6.2.10.02, Isotopes Facilities Deactivation Program, Activity Data Sheet 6504IS.

\section{DISCLAIMER}

This report was prepared as an account of work sponsored by an agency of the United States Government. Neither the United States Government nor any agency thereof, nor any of their employees, makes any warranty, express or implied, or assumes any legal liability or responsibility for the accuracy, completeness, or usefulness of any information, apparatus, product, or process disclosed, or represents that its use would not infringe privately owned rights. Reference herein to any specific commercial product, process, or service by trade name, trademark, manufacturer, or otherwise does not necessarily constitute or imply its endorsement, recommendation, or favoring by the United States Government or any agency thereof. The views and opinions of authors expressed herein do not necessarily state or reflect those of the United States Government or any agency thereof. 


\section{CONTENTS}

EXECUTIVE SUMMARY $\ldots \ldots \ldots \ldots \ldots \ldots \ldots \ldots \ldots \ldots \ldots \ldots \ldots \ldots \ldots$

1. INTRODUCTION ....................

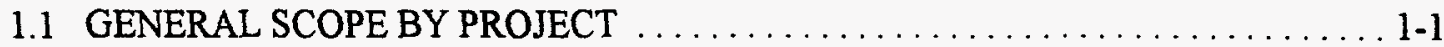

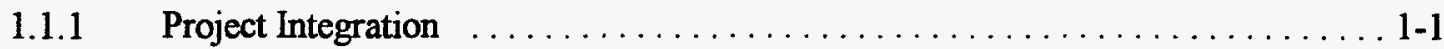

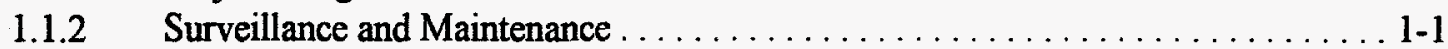

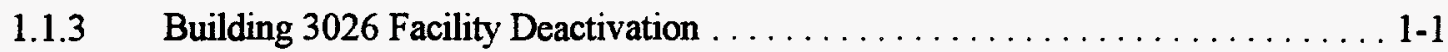

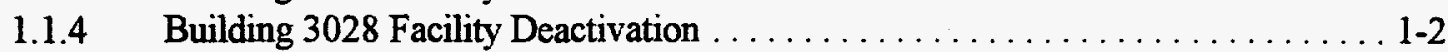

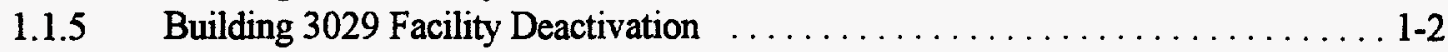

1.1.6 Center Circle $(3030-3034,3118)$ Facility Deactivation $\ldots \ldots \ldots \ldots \ldots \ldots \ldots$ 1-2

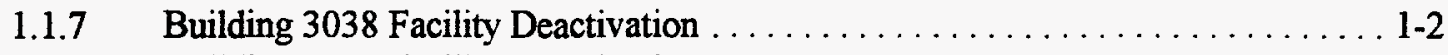

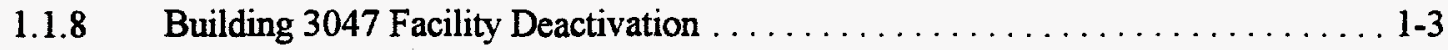

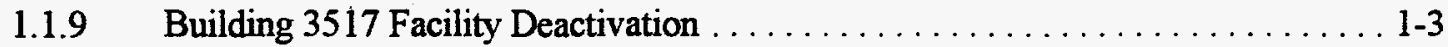

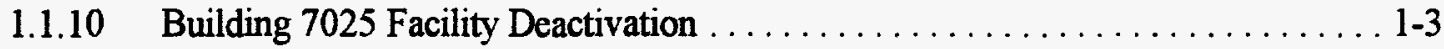

1.1.11 Other Facility Deactivation and Support $\ldots \ldots \ldots \ldots \ldots \ldots \ldots \ldots \ldots \ldots \ldots \ldots \ldots \ldots$

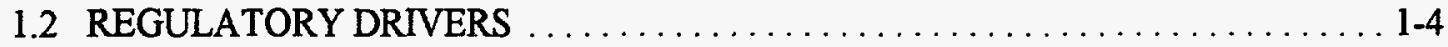

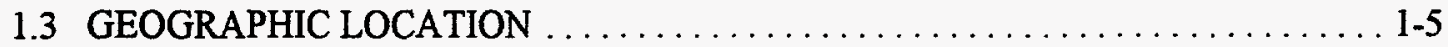

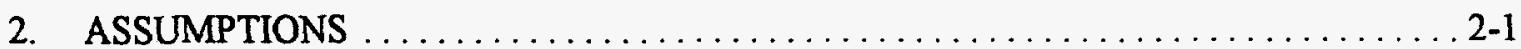

2.1 CENTRAL ER PROGRAMMATIC ASSUMPTIONS $\ldots \ldots \ldots \ldots \ldots \ldots \ldots \ldots . \ldots \ldots$

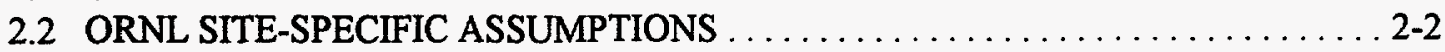

2.3 ADS OR-6504IS PROJECT SPECIFIC ASSUMPTIONS $\ldots \ldots \ldots \ldots \ldots \ldots \ldots$.

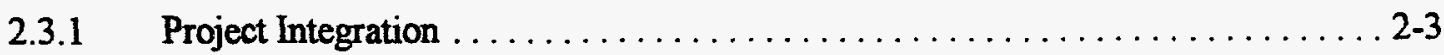

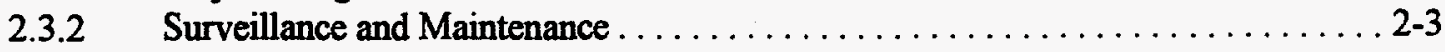

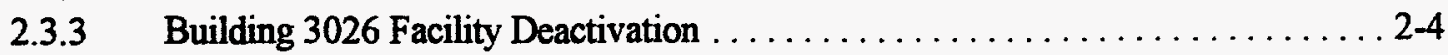

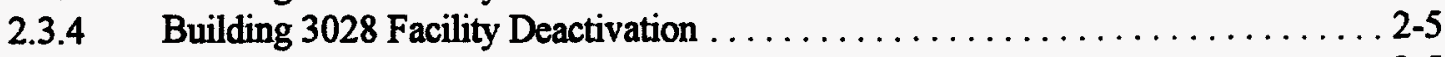

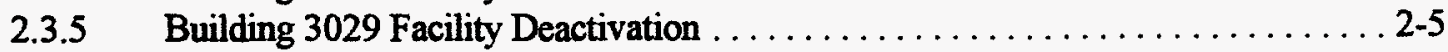

2.3.6 Center Circle $(3030$ - 3034, 3118) Facility Deactivation .............. 2-5

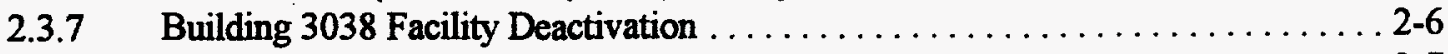

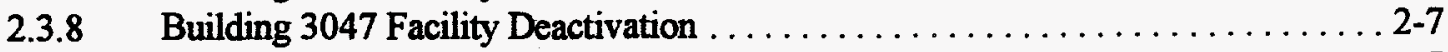

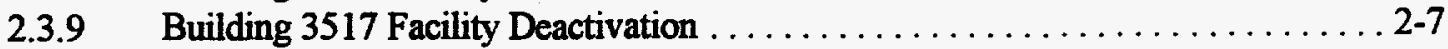

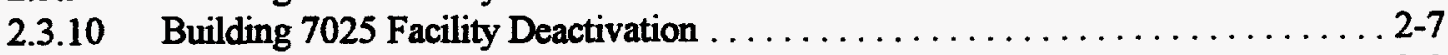

2.3.11 Other Facility Deactivation and Support $\ldots \ldots \ldots \ldots \ldots \ldots \ldots \ldots \ldots \ldots \ldots \ldots$

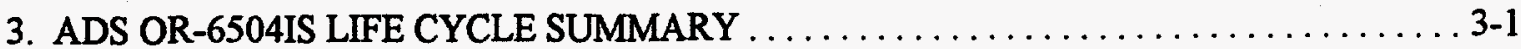

3.1 ADS OR-6504IS WORK BREAKDOWN STRUCTURE $\ldots \ldots \ldots \ldots \ldots \ldots \ldots . \ldots \ldots$

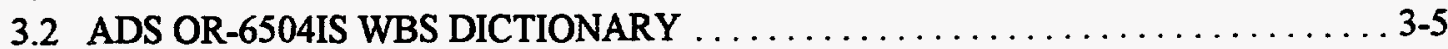

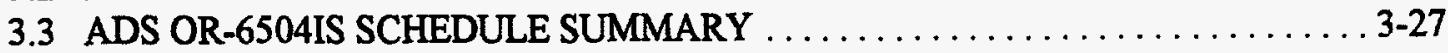

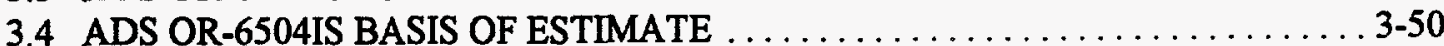

3.5 ADS OR-6504IS FISCAL YEAR COST LIFECYCLE PLAN $\ldots \ldots \ldots \ldots \ldots \ldots 3-52$

3.6 ADS OR-6504IS PROJECT/PARTICIPANT SUMMARY $\ldots \ldots \ldots \ldots \ldots \ldots . .54$ 



\section{EXECUTIVE SUMMARY}

The purpose of the Isotopes Facility Deactivation Project (IFDP) is to place former isotopes production facilities at the Oak Ridge National Laboratory in a safe, stable, and environmentally sound condition; suitable for an extended period of minimum surveillance and maintenance (S\&M) and as quickly and economically as possible. A companion document, Work Plan for Isotopes Facilities Deactivation Project (ORNL/ER-249), has been prepared to document the project schedule, the estimated project cost, and the technical approach for the project. Specific building involved are also identified. This Baseline Plan establishes the official target schedule for completing the deactivation work and the associated budget required for deactivation and the necessary S\&M.

Deactivation of the facilities $3026 \mathrm{C}, 3026 \mathrm{D}, 3028,3029,3038 \mathrm{E}, 3038 \mathrm{M}$, and $3038 \mathrm{AHF}$, the Center Circle buildings 3047, 3517, and 7025 will continue through Fiscal Year (FY) 1999. The focus of the project in the early years will be on the smaller buildings that require less deactivation and can bring an early return in reducing $S \& M$ costs.

This baseline plan covers the period from FY 1995 through FY 2000. Deactivation will continue in various facilities through FY 1999. A final year of S\&M will conclude the project in FY 2000. The estimated total cost of the project during this period is $\$ 51 \mathrm{M}$. Schedule and estimate costs of the project are summarized in Fig. ES-1 and Table ES-1. 
$\leq$

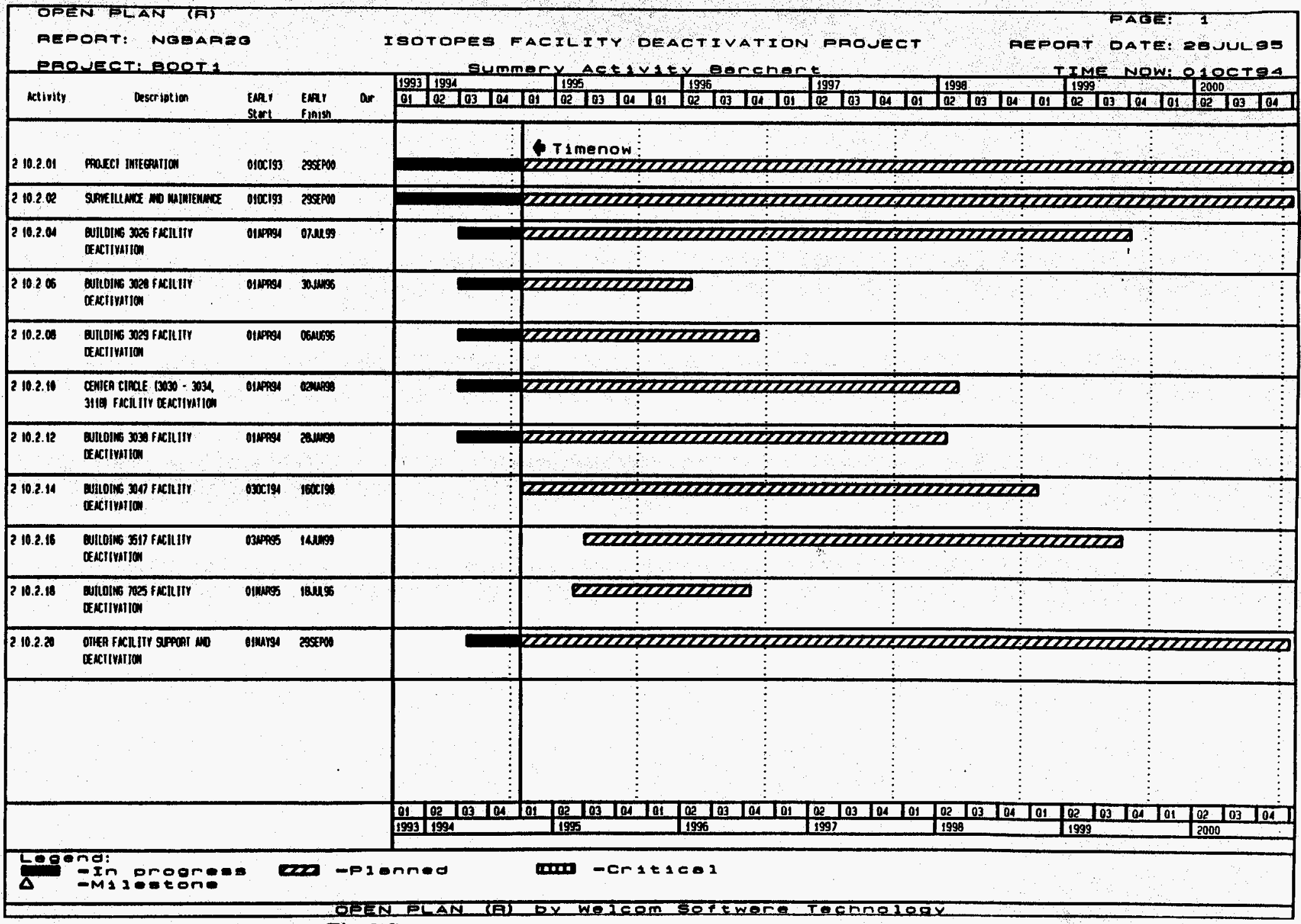

Fig. ES-1. Isotopes Facilities Deactivation Project Schedule 
Table ES-1. Isotopes Facilities Deactivation Project Cost Summary

Arranged ay: was

Fiscal Year Range $1995 \cdot 2000$

2.10.2.01 PROJECT INTEGRATION

2.10.2.02 SURVEILLAMCE AMD MINTEMANCE

2.10.2.04 DUILDIME 3026 FACILITY DEACTIV

2.10.2.06 EUILOTUE 3028 FACILITY DEACTIV

2.10.2.08 BUILDIUE 3029 FACILITY DEACTIV

2.10.2.10 CENTER CIRCLE 3030/3034.3118 F

2.10.2.12 EUILDING 3028

$\Xi$

2.10.2.14 BUILDING 3047 FACILITY DEACTIV

2.10.2.16 BUILDING 3517 FACILITY DEACTIV

2.10.2.18 EUILOING 7025 PACILITY DEACTIY

2.10.2.20 OTHER FACILITY SUPPORT AND DEA

\section{Sub-Total}

Overhead

sub-Total

contingency

Grand total

\begin{tabular}{|c|c|c|c|c|c|c|}
\hline 1995 & 1996 & 1997. & 1998 & 1999 & 2000 & Total \\
\hline 478 & 499 & 5.15 & 464 & 482 & 316. & 2754 \\
\hline 3077 & 3008 & $26 \pi$ & 2343 & 1384 & 631 & 12920 \\
\hline 314 & 295 & 185 & 1170 & 251 & - & 2215 \\
\hline 288 & 163 & - & $\because$ & - & - & 451 \\
\hline 97 & 504 & • &. & - & - & 601 \\
\hline 392 & 77 & 84 & 222 & - & - & 1475 \\
\hline 229 & 510 & 649 & 215 & . & . & 1603 \\
\hline 500 & - & 843 & 707 & 16 & . & 2066 \\
\hline 443 & 349 & 1364 & 1726 & 590 & . & 4472 \\
\hline 80 & 155 & - & - & - & . & 235 \\
\hline 791 & 861 & 501 & 520 & 541 & 561 & $37 / 5$ \\
\hline 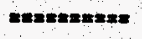 & $m=-2=x$ & $z= \pm x=2 x$ & $=x+3=8$ & restemsx & 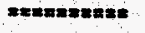 & Haxt \\
\hline 6689 & 7121 & 6618 & 7367 & 3264 & 1508 & 32567 \\
\hline 2715 & 2639 & 2691 & 2887 & 1077 & 447 & 12456 \\
\hline ans=E: & $x=2 x=$ & exz=men & $\operatorname{sent=2x}$ & 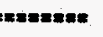 & Emmez=es" & 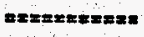 \\
\hline 9404 & 9760 & 9309 & 10256 & 4341 & 1955 & 45023 \\
\hline 270 & 422 & 0 & 3074 & 1301 & 586 & 5653 \\
\hline tatemenes & 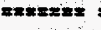 & $E \pi z= \pm=$ & 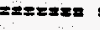 & & 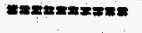 & \\
\hline 9674 & 10182 & 9309 & 13328 & 5642 & 2541 & 50676 \\
\hline
\end{tabular}




\section{INTRODUCTION}

\subsection{GENERAL SCOPE BY PROJECT}

The scope of this Activity Data Sheet (ADS) is to provide a detailed plan for the Isotopes Facilities Deactivation Project (IFDP) at the Oak Ridge National Laboratory (ORNL). This project places the former isotopes production facilities in a safe, stable, and environmentally sound condition suitable for an extended period of minimum surveillance and maintenance (S\&M) until the facilities are included in the Decontamination and Decommissioning (D\&D) Program. The facilities included within this deactivation project are Buildings 3026-C, 3026-D, 3028, 3029, 3038-AHF, 3038-E, 3038-M, 3047, 3517, 7025, and the Center Circle Facilities (Buildings 3030, 3031, 3032, 3033, 3033-A, 3034, and 3118).

The scope of deactivation identified in this Baseline Report include surveillance and maintenance activities for each facility, engineering, contamination control and structural stabilization of each facility, radioluminescent $(\mathrm{RL})$ light removal in Building 3026, re-roofing Buildings 3030, 3118, and 3031, Hot Cells Cleanup in Buildings 3047 and 3517, Yttrium (Y) Cell and Barricades Cleanup in Building 3038, Glove Boxes \& Hoods Removal in Buildings 3038 and 3047, and Inventory Transfer in Building 3517. For a detailed description of activities within this Work Breakdown Structure (WBS) element, see the Level 6 and Level 7 Element Definitions in Section 3.2 of this report.

\subsubsection{Project Integration (1.6.6.2.10.2.01)}

The identified Project Integration activities are: Project Management (PM) and development/maintenance of a Project Plan. For a detailed description of activities within this WBS element, see the Level 7 Element Definition in Section 3.2 of this report.

\subsubsection{Surveillance and Maintenance (1.6.6.2.10.2.02)}

To ensure that facilities are maintained in a safe condition during the post-deactivation surveillance period while awaiting the start of D\&D activities, surveillance and maintenance activities will be performed for each facility included in the IFDP. Surveillance activities will include checks of building integrity, security, radiological surveys, external housekeeping, and proper warning postings and exposure controls. Maintenance activities include items such as testing and replacement of filters, repairs to HVAC systems and periodic calibration of instrumentation, and other items as identified for each specific facility in the Final Facility Report and S\&M Plan. This project will be composed of the following activities: Utilities, Building 3026, Building 3028, Building 3029, Center Circle Facilities (3030 - 3034, 3118), Building 3038, Building 3047, Building 3517, Building 7025, and Other Facility Deactivation and Support. For a detailed description of activities within this WBS element, see the Level 7 Element Definition in Section 3.2 of this report.

\subsubsection{Building 3026 Facility Deactivation (1.6.6.2.10.2.04)}

Building 3026 is divided into Buildings 3026-C and 3026-D. Building 3026-C (Krypton-85 Enrichment Facility) is a two-story wooden structure located on Central Avenue to the west of the Isotopes Circle facilities. Building 3026-C contains offices, low- and high-level radioactivity laboratories, an instrument shop and a counting room. Building 3026-C shares a common wall and utilities with adjacent Building 3026-D. A reinforced concrete tritium facility is located at the northwest comer of Building 3026-C. A major structure within Building 3026-C is two banks, each consisting of 
four hot cells. The major structure within Building 3026-D is a two-story, 5-ft-thick concrete cell which is divided into two connecting radioactive material handling cells. The deactivation activities for this project are Contamination Control, Structural Stabilization, RL Lights Removal, and development of a Final Facility Report. For a detailed description of activities within this WBS element, see the Level 7 Element Definition in Section 3.2 of this report.

\subsubsection{Building 3028 Facility Deactivation (1.6.6.2.10.2.06)}

Building 3028 is the Alpha Powder Facility, built to separate ${ }^{131} \mathrm{I}$ and later ${ }^{133} \mathrm{Xe}$ and other shortlived fission products from uranium-aluminum targets. The structure contains 7 processing cells used to handle alpha powder and process ${ }^{147} \mathrm{Pm}$ and ${ }^{133} \mathrm{Xe}$. The structure also contains a ${ }^{133} \mathrm{Xe}$ recovery and purification cubicle. The deactivation activities for this project are Contamination Control, Structural Stabilization, and development of a Final Facility Report. For a detailed description of activities within this WBS element, see the Level 7 Element Definition in Section 3.2 of this report.

\subsubsection{Building 3029 Facility Deactivation (1.6.6.2.10.2.08)}

Building 3029 was the Source Development Laboratory and is located in the west-central area of the Isotopes Circle. The structure contains 4 hot cells which were used to process high-level beta/gamma sources, monitor ${ }^{192} \mathrm{Ir}$ and process short-lived materials. The structure also contains a ${ }^{60} \mathrm{Co}$ storage and irradiation area, 2 laboratory hoods, and 2 glove boxes. The deactivation activities for this project are Contamination Control, Structural Stabilization, and development of a Final Facility Report. For a detailed description of activities within this WBS element, see the Level 7 Element Definition in Section 3.2 of this report.

\subsubsection{Center Circle (3030 - 3034, 3118) Facility Deactivation (1.6.6.2.10.2.10)}

Building 3030, 3031 and 3118, the Radioisotopes Production Laboratories C, D, and H, were used for limited production and development processing of reactor-produced beta/gamma-emitting radioisotopes. Building 3033, the Tritium and Krypton Production Facility, was used to process tritium and krypton materials. Building 3033-A, the Actinide Fabrication facility, was used for the handling and packaging of small quantities of actinide materials. Building $\mathbf{3 0 3 2}$ was used as the Radioisotope Area Services building, and Building 3034 was used as the Radioisotope Production Laboratory. The deactivation activities for this project are Contamination Control, Structural Stabilization, Re-roof buildings 3030, 3118, 3031, and development of a Final Facility Report. For a detailed description of activities within this WBS element, see the Level 7 Element Definition in Section 3.2 of this report.

\subsubsection{Building 3038 Facility Deactivation (1.6.6.2.10.2.12)}

Building 3038 contains the Isotopes Research Materials Laboratory, Isotopes Shipping, Isotopes Technology, and Alpha Handling facilities. The structure contains glove boxes and hoods which were used for the fabrication of radioactive targets and for examination of materials by both destructive and non-destructive tests, a process cell area, a shielded counting room, a concrete barricade, a remote pipefitting station, a canning station and a packaging station. The deactivation activities for this project are Contamination Control, Structural Stabilization, Yttrium Cell Cleanup, Glove Box \& Hoods Removal, Barricades Cleanup, and development of a Final Facility Report. For a detailed description of activities within this WBS element, see the Level 7 Element Definition in Section 3.2 of this report. 


\subsubsection{Building 3047 Facility Deactivation (1.6.6.2.10.2.14)}

Building 3047, the Radioisotope Development Laboratory, contains 4 high-level, beta-gamma hot cells, I alpha handling hot cell, 7 laboratories for handling low-level materials, 2 glove boxes, and a decontamination room. The deactivation activities for this project are Contamination Control, Structural Stabilization, Hot Cells Cleanup, Glove Boxes \& Hoods Removal, and development of a Final Facility Report. For a detailed description of activities within this WBS element, see the Level 7 Element Definition in Section 3.2 of this report.

\subsubsection{Building 3517 Facility Deactivation (1.6.6.2.10.2.16)}

Building 3517, the Fission Product Development Laboratory, was used to recover long-lived fission products from aqueous wastes generated in reprocessing irradiated reactor fuel elements, purify feed materials from other DOE sites, and prepare radioactive sources. The structure contains 23 process, manipulator, service and tank farm cells used for producing radioactive sources. The deactivation activities for this project are Inventory Transfer, Hot Cells Cleanup, Structural Stabilization, and development of a Final Facility Report. For a detailed description of activities within this WBS element, see the Level 7 Element Definition in Section 3.2 of this report.

\subsubsection{Building 7025 Facility Deactivation (1.6.6.2.10.2.18)}

Building 7025, the Tritium Target Fabrication facility, was used for fabricating titanium tritide targets, preparing metallurgical samples for helium embrittlement studies, and preparing thin films of $\mathrm{ThO}_{2} / \mathrm{UO}_{2}$. The building is located about 1.4 miles northeast of the central ORNL site within the perimeter fence of the ORNL 7000 area, and is isolated from other nearby buildings. The structure contains 2 hoods. The deactivation activities for this project are Contamination Control, Structural Stabilization, and development of a Final Facility Report. For a detailed description of activities within this WBS element, see the Level 7 Element Definition in Section 3.2 of this report.

\subsubsection{Other Facility Deactivation and Support (1.6.6.2.10.2.20)}

Other Facility Deactivation and Support activities include providing non-building specific engineering and planning. For a detailed description of activities within this WBS element, see the Level 7 Element Definition in Section 3.2 of this report. 


\subsection{REGULATORY DRIVERS}

- U. S. Department of Energy (DOE) Policy Memorandum for Acceptance of Facilities for Environmental Restoration (ER) Program, dated March 15, 1991

- DOE Order 5820.2A, Radioactive Waste Management

- DOE Order 5480.11, Radiation Protection for Occupational Workers

- DOE Order 5480.6, Radiological Control Manual

- DOE Order 5400.3B, Occurrence Reporting and Processing of Operations Information

- DOE Order 5400.1, General Environmental Protection Program

- DOE Order 5400.3, Hazardous and Radioactive Waste Program

- Comprehensive Environmental Response, Compensation, and Liability Act (CERCLA):

- $\quad$ Response Authorities [42 U. S. Code (USC) 9604 § 104]

- Cleanup Standards (42 USC 9621 § 121)

- Applicable or Relevant and Appropriate Requirements [40 Code of Federal Regulations (CFR) 300]:

- Permit Requirements (40 CFR 300.404)

- Oversight (40 CFR 300.404)

- Resource Conservation and Recovery Act (RCRA):

- Hazardous Waste Management Units (40 CFR 260-268)

- National Environmental Policy Act (NEPA)

- Occupational Safety and Health Administration (OSHA) (29 CFR 1910)

- $\quad$ Federal Facilities Act (FFA) 


\subsection{GEOGRAPHIC LOCATION}

ADS OR-6504IS activities are located at the central ORNL complex in close proximity to the main administrative building (4500N) and research facilities. One facility, Building 7025, is located in the 7000 area approximately 1.4 miles east of the main ORNL complex. The location of the main isotopes facilities is shown in Fig. 1.1. 


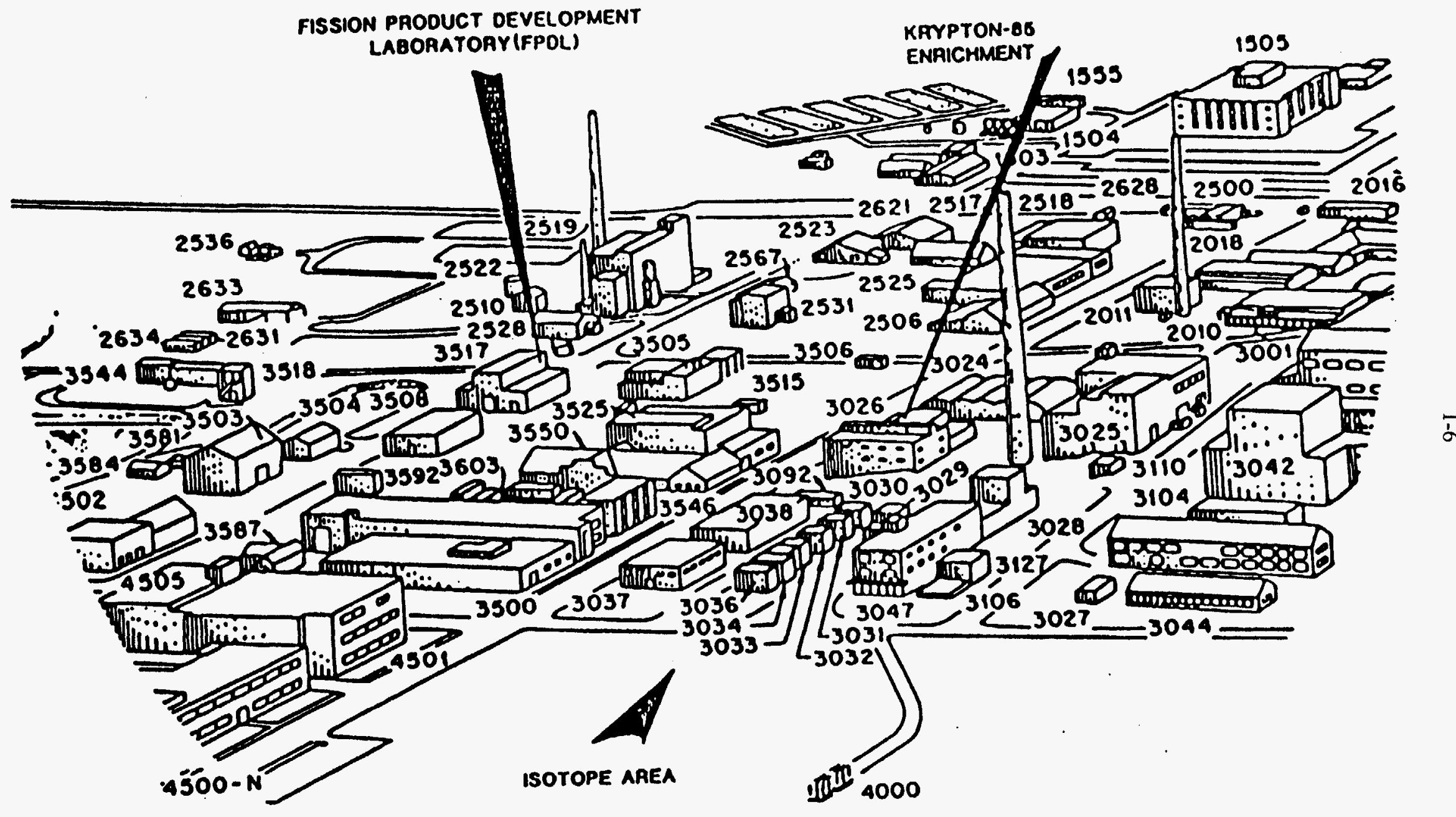

Fig. 1.1. Location of Isotopes Facilities at ORNL. 


\section{ASSUMPTIONS}

\subsection{CENTRAL ER PROGRAMMATIC ASSUMPTIONS}

- D\&D Program will accept facilines no later than 2 full years after deactivation.

- D\&D will be initiated within 10 years after transfer of facilities to the D\&D program.

- The Facility Transition Program will follow the substantive requirements, but not the administrative process, of CERCLA.

- The scope of the baseline is limited to the site/facilities accepted into the ER Program as of October $1,1994$.

- Estimates are based on assumptions made by project teams familiar with the history and character of facilities concerning the most probable cleanup activities. Assumptions are conservative but not worst case.

- Contingency shall be included to fall within the ranges specified in the Cost Assessment Team manual.

- Program Management must be consistent relative for the magnitude of the program. Based on U.S. Department of Energy Headquarters guidance, not more than approximately $10 \%$ of the total program should be designated as program management.

- All facilities will be deactivated and turned over to the D\&D program by the beginning of FY 2001 .

- Liquid Low-Level waste (LLLW) will continue to be transferred via underground lines to WC-10 until the end of FY-1998. 


\subsection{ORNL SITE-SPECIFIC ASSUMPTIONS}

- Lockheed Martin Energy Systems, Inc. (Energy Systems) will be the lead participant and facility manager. Selected deactivation activities will be sub-contracted, with oversight and verification by Energy Systems.

- The IFDP will be integrated with the ORNL ER Program as appropriate.

- The ORNL Waste Management System has the capacity and resources required to manage all waste generated by the IFDP. 


\subsection{ADS OR-6504IS PROJECT SPECIFIC ASSUMPTIONS}

General

- Contamination Control shall include bonding and labeling fixed contamination, removing potential aiborne contamination from hoods and glove boxes, characterizing, packaging, and removing all wastes, removing loose unanchored equipment from hot cells, hoods, and glove boxes, and removing abandoned equipment from operating areas.

- Structural Stabilization shall include repairing deficiencies in primary containment systems, deactivating all services to hoods and glove boxes, sealing drains, repairing roofs, and sealing and locking all hot cell access ports.

- Final Facility Report activities include documenting facility history, documenting the "as-left" facility condition, and developing procedures for post-deactivation S\&M and for unplanned entries.

- Special nuclear materials; reactor fuels; and solid and liquid radioactive, hazardous, and mixed waste shall be removed from the facility or the location, and controls shall be documented and approved for thise materials for which an end condition cannot be determined. Any exceptions of nuclear and hazardous material remaining in the facility shall be identified and characterized by location, type, and quantity.

\subsubsection{Project Integration (1.6.6.2.10.2.01)}

\section{Technical}

- Project Integration consists of Project Management, Project Planning, and coordination of all interface with the Energy Systems ER Program, ORNL, and the DOE. These functions are nonbuilding specific activities.

\section{Estimate}

None

\section{Schedule}

None

\subsubsection{Surveillance and Maintenance (1.6.6.2.10.2.02)}

Post deactivation S\&M will reflect the following general guidelines:

\section{Technical}

- The facilities shall be in a physical condition adequate to contain and monitor any radioactive contamination. An "as left" radiation contamination survey of the facilities and surrounding areas will be included in the deactivation records.

- Security systems and procedures shall be adequate to prevent unauthorized entry. 
- S\&M of the facilities and access control during the post-deactivation period include surveillance of doors for security and access protection, external housekeeping to avoid accumulation of combustibles near the facilities; inspection of the exterior structure, roof, and access doors to verify no indication of potential or ongoing degradation of the structure or accesses; inspection of the interior to ensure that deactivated facilities conditions are constant and to reduce the risk of contamination spread due to intrusion by small animals or birds; and inspection to verify that signs and restricted area posting/barriers exist to ensure that proper warnings and exposure controls are in place for worker protection.

\section{Estimate}

- Weekly surveillance will be performed on ventilation system differential pressure, personnel access control, and a weekly surveillance "walk thru" of Buildings 3047 and 3517 will be performed.

- Monthly surveillance will be performed on grounds housekeeping, exterior signs, and restricted area posting/barriers.

- Quarterly surveillance will be performed on fire alarm systems, and quarterly internal and external facilities inspections will be performed.

\section{Schedule}

None

\subsubsection{Building 3026 Facility Deactivation (1.6.6.2.10.2.04)}

\section{Technical}

- Buildings 3026-C and 3026-D are included within this WBS element. Activities for this WBS element include contamination control, Structural Stabilization, RL light removal, and preparation of a Final Facility Report as defined in the General Project Specific assumptions.

- Items to be addressed in the deactivation of Building 3026-C include tritium labs $7 \& 16 ; \mathrm{Kr}-85$ shipping cylinder disposal; krypton columns 1-4 cleanup; piping, utilities, and alarm deactivation; chill water.system deactivation; and ductwork.

- Items to be addressed in the deactivation of Building 3026-D include clean out and deactivation of cells; piping, utilities, and alarm deactivation.

- $\quad$ Numerous ${ }^{3} \mathrm{H}$-filled RL lights are to be inventoried, disassembled as needed, and placed in Type A packages suitable for transfer off-site. RL lights that cannot be shipped offsite will be packaged as solid low level radioactive waste.

\section{Estimate}

None

\section{Schedule}

None 


\subsubsection{Building 3028 Facility Deactivation (1.6.6.2.10.2.06)}

\section{Technical}

- Items to be addressed in the deactivation of Building 3028 include clean out and deactivation of cells; piping, utilities, and alarm deactivation; fire protection deactivation; and sealing the building exterior. Activities for this WBS element include contamination control, Structural Stabilization, and preparation of a Final Facility Report as defined in the General Project Specific assumptions.

Estimate

None

Schedule

None

2.3.5 Building 3029 Facility Deactivation (1.6.6.2.10.2.08)

\section{Technical}

- Items to be addressed in the deactivation of Building 3029 include clean out and deactivation of cells; ${ }^{137} \mathrm{Cs}$ powder clean-up and lead disposal; piping, utilities, and alarm deactivation; fire protection deactivation; and sealing the building exterior. Activities for this WBS element include contamination control, Structural Stabilization, and preparation of a Final Facility Report as defined in the General Project Specific assumptions.

\section{Estimate}

None

Schedule

None

\subsubsection{Center Circle (3030 - 3034, 3118) Facility Deactivation (1.6.6.2.10.2.10)}

\section{Technical}

- Items to be addressed in the deactivation of Building 3030 include clean out and deactivation of cells; piping, utilities, and alarm deactivation; re-roofing; and sealing the building exterior.

- Items to be addressed in the deactivation of Building 3031 include clean out and deactivation of cells; deactivating piping services and alarm deactivation; and re-roofing.

- Items to be addressed in the deactivation of Building 3030 include deactivation of hoods; piping and utilities and alarm deactivation.

- Items to be addressed in the deactivation of Building 3118 include re-roofing; cleaning the floors, sealing cells, and alarm deactivation. 
- Items to be addressed in the deactivation of Building 3033 include inerting tritium traps; krypton equipment and alarm deactivation; and sealing the building exterior.

- Items to be addressed in the deactivation of Building 3033-A include cleaning and removing the glove box and hood; roof repair; utilities, alarm, system ductwork, and glove box deactivation.

- Deactivation of Buildings 3030, 3031, 3032,3033, 3034, and 3118 include contamination control, Structural Stabilization, and preparation of a Final Facility Report as defined in the General Project Specific assumptions.

\section{Estimate}

- Building 3034 was added to the estimate. Costs associated are actual costs supplied by Energy Systems project personnel.

- Building 3032 is a composite estimate using Building 3034 and Building 3047 (Hoods).

\section{Schedule}

- Building 3034 is complete except for disposal of electrical cables and development of the Final Facility Report.

- Building 3032 was not in the Revision 0 Work Plan for the Isotopes Facilities Deactivation Project at Oak Ridge National Laboratory. The schedule for activities in this building is assumed to be similar to the Hood and Sink removal in Building 3047; General Cleanup is assumed to be similar to that activity in Building 3034.

\subsubsection{Building 3038 Facility Deactivation (1.6.6.2.10.2.12)}

\section{Technical}

- Items to be addressed in the deactivation of Alpha Handling facility include cell clean up; drain repair; utilities and alarm deactivation, and glove box deactivation.

- Items to be addressed in the deactivation of Building 3038-E include sealing and removing glove boxes; Yttrium Cell Clean-up; piping, utilities, and alarm deactivation.

- Items to be addressed in the deactivation of Building 3038-M include barricade clean out; piping, utilities, and alarm deactivation; and relocating packaging and shipping operations.

- Deactivation of Building 3038 includes contamination control, Structural Stabilization, and preparation of a Final Facility Report as defined in the General Project Specific assumptions.

\section{Estimate}

None

\section{Schedule}

None 


\section{Technical}

- Items to be addressed in the deactivation of Building 3047 include chill water system deactivation; C-14 glove box clean-up; hood deactivation; vacuum pit clean-up; filter house clean-up; Cell A, B, C, D clean-up, Cell D sump sludge cleanup; Room 110 clean-up; Gadolinium press glove box deactivation; fire protection deactivation; and piping, utilities, and alarm deactivation.

- Deactivation of Building 3047 includes contamination control, Structural Stabilization, and preparation of a Final Facility Report as defined in the General Project Specific assumptions.

\section{Estimate}

None

Schedule

None

2.3.9 Building 3517 Facility Deactivation (1.6.6.2.10.2.16)

\section{Technical}

- Items to be addressed in the deactivation of Building 3517 include preparing a justification for repackaging; facility upgrades; ${ }^{244} \mathrm{Cm}$ transfer, packaging $\mathrm{Co}, \mathrm{Eu}, \mathrm{Gd}$ for retrievable storage, repackaging ${ }^{137} \mathrm{Cs}$; repackaging ${ }^{90} \mathrm{Sr}$; Cells $10,11,12,13,14,15,16$, and 18 clean-up; fire protection deactivation; and piping, utilities, and alarm deactivation.

- Deactivation of Building 3517 includes contamination control, Structural Stabilization, and preparation of a Final Facility Report as defined in the General Project Specific assumptions.

\section{Estimate}

- The resumption of repackaging operations will require an Operational Readiness Review (ORR) or a Readiness Assessment.

\section{Schedule}

None

\subsubsection{Building 7025 Facility Deactivation (1.6.6.2.10.2.18)}

\section{Technical}

- Items to be addressed in the deactivation of Building 7025 include tritium and hot smear clean-up; utilities, water system, and alarm deactivation; and the clean up of equipment and disposal of sheds.

- Deactivation of Building 7025 includes contamination control, Structural Stabilization, and preparation of a Final Facility Report as defined in the General Project Specific assumptions. 


\section{Estimate}

None

Schedule

None

2.3.11 Other Facility Deactivation and Support (1.6.6.2.10.2.20)

Technical

- Items to be addressed include non-building specific engineering, health and safety studies, planning, and other studies that are required to support deactivation.

\section{Estimate}

None

Schedule

None 


\section{ADS OR-6504IS LIFE CYCLE SUMMARY}

\subsection{ADS OR-6504IS WORK BREAKDOWN STRUCTURE}

Fig. 3.1 depicts the WBS for ADS OR-6504IS, WBS 1.6.6.2.10.2. 


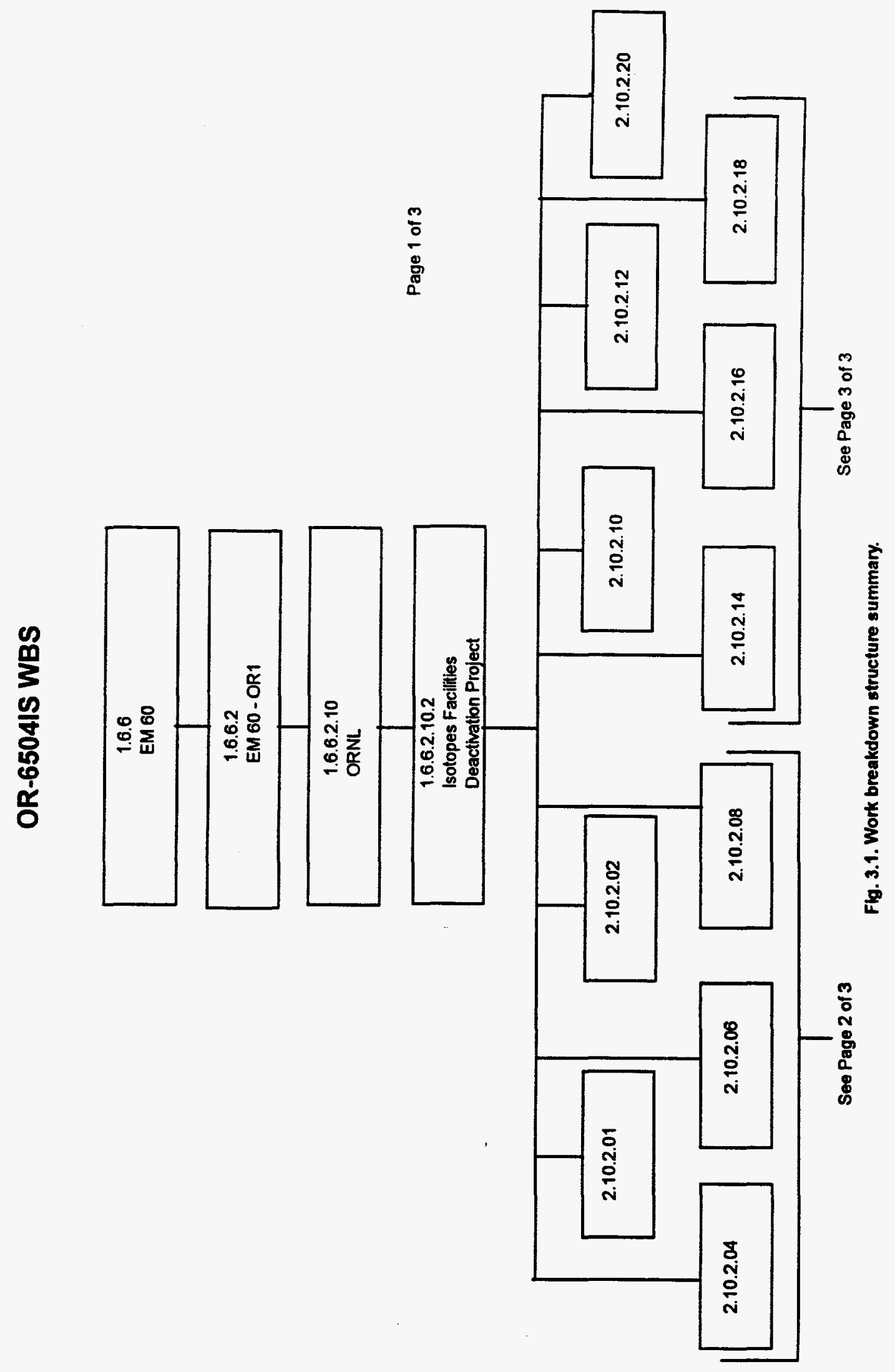


OR-6504LS WBS

Page 2 of 3

\begin{tabular}{|c|c|c|c|c|}
\hline $\begin{array}{l}2.10 .2 .01 \\
\text { Project } \\
\text { Integration }\end{array}$ & $\begin{array}{l}2.10 .2 .02 \\
\text { Surveillance and } \\
\text { Maintenance }\end{array}$ & $\begin{array}{l}2.10 .2 .04 \\
\text { Building } 3026 \\
\text { Facility } \\
\text { Deactivation }\end{array}$ & $\begin{array}{l}2.10 .2 .06 \\
\text { Building } 3028 \\
\text { Facility } \\
\text { Deactivation }\end{array}$ & $\begin{array}{l}\text { 2.10.2.08 } \\
\text { Building } 3029 \\
\text { Facility } \\
\text { Deactivation }\end{array}$ \\
\hline $\begin{array}{l}-2.01 .01 \text { Project } \\
\text { Management } \\
-2.01 .02 \text { Project Plan }\end{array}$ & $\begin{array}{l}\text { - 2.02.01 Utilities } \\
-2.02 .04 \text { Building } 3026 \text { S\&M } \\
\text {-2.02.06 Bullding } 3028 \text { S\&M } \\
-2.02 .08 \text { Building } 3029 \text { S\&M } \\
-2.02 .10 \text { Center Circle } \\
\text { Facilities S\&M } \\
-2.02 .12 \text { Building } 3038 \text { S\&M } \\
-2.02 .14 \text { Building } 3047 \text { S\&M } \\
-2.02 .16 \text { Building } 3517 \text { S\&M } \\
-2.02 .18 \text { Building } 7025 \text { S\&M } \\
-2.02 .20 \text { Other S\&M }\end{array}$ & $\begin{array}{c}\text {-2.04.01 Contamination } \\
\text { Control } \\
-2.04 .02 \text { Structural } \\
\text { Stablization } \\
-2.04 .08 \text { RL. Lights } \\
\text { Removal } \\
\text {-2.04.10 Final Facility } \\
\text { Report }\end{array}$ & $\begin{array}{c}\text {-2.06.01 Contamination } \\
\text { Control } \\
\text {-2.06.02 Structural } \\
\text { Stabilization } \\
\text {-2.06.10 Final Facility } \\
\text { Report }\end{array}$ & $\begin{array}{c}\text {-2.08.01 Contamination } \\
\text { Control } \\
-2.08 .02 \text { Structural } \\
\text { Stabilization } \\
\text {-2.08.10 Final Facility } \\
\text { Report }\end{array}$ \\
\hline
\end{tabular}

Fig. 3.1 Work breakdown structure summary (continued). 
OR-6504IS WBS

Page 3 of 3

\begin{tabular}{|c|c|c|c|c|c|}
\hline $\begin{array}{l}2.10 .2 .10 \\
\text { Center Circle (3030 - } \\
\text { 3034, 3118) Facility } \\
\text { Deactivation }\end{array}$ & $\begin{array}{l}2.10 .2 .12 \\
\text { Building } 3038 \\
\text { Facility } \\
\text { Deactivation }\end{array}$ & $\begin{array}{l}2.10 .2 .14 \\
\text { Building } 3047 \\
\text { Facility } \\
\text { Deactivation }\end{array}$ & $\begin{array}{l}2.10 .2 .16 \\
\text { Bulding } 3517 \\
\text { Facility } \\
\text { Deactivation }\end{array}$ & $\begin{array}{l}2.10 .2 .18 \\
\text { Building } 7025 \\
\text { Facility } \\
\text { Deactivation }\end{array}$ & $\begin{array}{l}\text { 2.10.2.20 } \\
\text { Other Facility } \\
\text { Deactivation and } \\
\text { Support }\end{array}$ \\
\hline $\begin{array}{l}-2.10 .01 \text { Contamination } \\
\text { Control } \\
-2.10 .02 \text { Structural } \\
\text { Stabilization } \\
-2.10 .07 \text { Re-roof } \\
\text { Buildings } 3030, \\
\text { 3118, 3031 } \\
\text {-2.10.10 Final Facility } \\
\text { Report }\end{array}$ & $\begin{array}{c}-2.12 .01 \text { Contamination } \\
\text { Control } \\
-2.12 .02 \text { Structural } \\
\text { Stabilization } \\
-2.12 .04 \text { Ytrium Cell } \\
\text { Cleanup } \\
-2.12 .05 \text { Glove Box } 8 \\
\text { Hoods Removal } \\
-2.12 .06 \text { Barricades Cleanup } \\
-2.12 .10 \text { Final Facility Report }\end{array}$ & $\begin{array}{c}-2.14 .01 \text { Contamination } \\
\text { Control } \\
-2.14 .02 \text { Structural } \\
\text { Stabilization } \\
-2.14 .03 \text { Hot Cells } \\
\text { Cleanup } \\
-2.14 .05 \text { Glove Boxes \& } \\
\text { Hoods Removal } \\
-2.14 .10 \begin{array}{c}\text { Final Facility } \\
\text { Report }\end{array} \\
\text { Repol }\end{array}$ & $\begin{array}{c}-2.16 .02 \text { Structural } \\
\text { Stabilization } \\
-2.16 .03 \text { Hot Cels } \\
\text { Cleanup } \\
-2.16 .09 \text { mventory } \\
\text { Transfer } \\
-2.16 .10 \text { Final Facility } \\
\text { Report }\end{array}$ & $\begin{array}{c}-2.18 .01 \text { Contamination } \\
\text { Control } \\
-2.18 .02 \text { Structural } \\
\text { Stabilization } \\
-2.18 .10 \text { Final Facility } \\
\text { Report }\end{array}$ & -2.20.01 Other Support \\
\hline
\end{tabular}

Fig. 3.1 Work breakdown structure summary (continued). 


\subsection{ADS OR-6504IS WBS DICTIONARY}

The following pages are the Level 6 and Level 7 WBS Element Definition sheets for the ADS and for each project within the ADS. 
U. S. DEPARTMENT OF ENERGY

WORK BREAKDOWN STRUCTURE DICTIONARY

PART II - ELEMENT DEFINITION

DOE F1332.11

$(11-84)$

\begin{tabular}{||l|l|l|l|}
\hline $\begin{array}{l}\text { 1. PROJECT TITLE/PARTICIPANT } \\
\text { Environmental Restoration/Lockheed Martin } \\
\text { Energy Systems }\end{array}$ & $\begin{array}{l}\text { 2. DATE } \\
08 / 01 / 95\end{array}$ & $\begin{array}{l}\text { 3. IDENTIFICATION NUMBER } \\
\text { DE-AC05-840R21400 }\end{array}$ \\
\hline $\begin{array}{l}\text { 4. WBS ELEMENT CODE AND ADS } \\
\text { 1.6.6.2.10.2 ADS OR-6504IS }\end{array}$ & $\begin{array}{l}\text { 5. WBS ELEMENT TITLE } \\
\text { Isotopes Facilities Deactivation Project }\end{array}$ & $\begin{array}{c}\text { 8. DATE } \\
\text { 08/01/95 }\end{array}$ \\
\hline 6. INDEX LINE NO. & $\begin{array}{c}\text { 7. REVISION NO. AND AUTHORIZATION } \\
0\end{array}$ & \\
\hline
\end{tabular}

\section{APPROVED CHANGES}

10. SYSTEM DESIGN DESCRIPTION

11. BUDGET AND REPORTING NUMBER

\section{ELEMENT TASK DESCRIPTION}

a. Cost Content

Labor

Material

Overhead

Subcontractor Effort

\section{b. Technical Content}

The scope of this Activity Data Sheet (ADS) is to provide a detailed plan for the Isotopes Facilities Deactivation Project (IFDP) at the Oak Ridge National Laboratory (ORNL). This project places the former isotopes production facilities in a safe, stable, and environmentally sound condition suitable for an extended period of minimum surveillance and maintenance (S\&M). The facilities included within this deactivation project are Buildings 3026-C, 3026-D, 3028, 3029, 3038-AHF, 3038-E, 3038-M, 3047, 3517, 7025, and the Center Circle (Buildings 3030, 3031, 3032, 3033, 3033-A, 3034, 3118) Facilites.

The proposed deactivation for various projects within this ADS are found in the Work Statement section of this Dictionary Sheet

- Area

Throughout the ORNL complex

- Location

All Isotopes facilities, except Building 7025, are located within the central ORNL complex in close proximity to the main administrative building $(4500 \mathrm{~N})$ and research facilities. Building 7025 is located in the 7000 area approximately 1.4 miles east of the main ORNL complex. 
U. S. DEPARTMENT OF ENERGY

WORK BREAKDOWN STRUCTURE DICTIONARY

PART I - ELEMENT DEFINITION

DOE F1332.11

(11-84)

\begin{tabular}{||l|l|l|l|}
\hline $\begin{array}{l}\text { 1. PROJECT TITLE/PARTICIPANT } \\
\text { Environmental Restoration/Lockhed Martin } \\
\text { Energy Systems }\end{array}$ & $\begin{array}{l}\text { 2. DATE } \\
08 / 01 / 95\end{array}$ & $\begin{array}{l}\text { 3. WENTIFICATION NUMBER } \\
\text { DE-AC05-840R21400 }\end{array}$ \\
\hline $\begin{array}{l}\text { 4. WBS ELEMENT CODE AND ADS } \\
1.6 .6 .2 .10 .2 \text { ADS OR-6504IS }\end{array}$ & $\begin{array}{l}\text { 5. WBS ELEMENT TITLE } \\
\text { Isotopes Facilities Deactivation Project }\end{array}$ & $\begin{array}{c}\text { 8. DATE } \\
08 / 01 / 95\end{array}$ \\
\hline \begin{tabular}{l} 
6. INDEX LINE NO. \\
\hline
\end{tabular} & $\begin{array}{l}\text { 7. REVISION NO. AND AUTHORIZATION } \\
0\end{array}$ &
\end{tabular}

\section{APPROVED CHANGES}

10. SYSTEM DESIGN DESCRIPTION

11. BUDGET AND REPORTING NUMBER

12. ELEMENT TASK DESCRIPTION

- Contaminants:

- Radionuclides $-{ }^{60} \mathrm{Co},{ }^{90} \mathrm{Sr},{ }^{137} \mathrm{Cs},{ }^{85} \mathrm{Kr},{ }^{129} \mathrm{I},{ }^{79} \mathrm{Se},{ }^{107} \mathrm{Pd},{ }^{147} \mathrm{Pm},{ }^{99} \mathrm{~T},{ }^{237} \mathrm{~Np},{ }^{140} \mathrm{Ba},{ }^{192} \mathrm{Ir}$, and others

- various hazardous wastes including asbestos and lead based paints

- Related Items Covered Outside Scope of ADS OR-6504IS:

- Decontamination and decommissioning of buildings and above ground facilities, ADS 3701

c. Work Statement

The Isotopes Facilities Deactivation Project has been divided into the following major activities:

- Project Integration - Project Management and development of the Project Plan.

- Surveillance and Maintenance - Periodic surveillance and maintenance of buildings in the scope of the IFDP.

- Deactivation of the Facilities in the scope of the IFDP.

Detailed work statements are included in the Level 7 Element Definition sheets. There are no Level 1 milestones scheduled to occur within the lifecycle of the project.

Generally, the work is to be performed as follows:

Surveillance and Maintenance

Project Integration

Facility Deactivation
Lockheed Martin Energy Systems, Inc. (Energy Systems)

Energy Systems

Energy Systems/Construction Management Contractor 
DOE F1332.11

$(11-84)$

\begin{tabular}{||l|l|l||}
\hline $\begin{array}{l}\text { 1. PROJECT TITLE/PARTICIPANT } \\
\text { ADS OR-6504IS }\end{array}$ & $\begin{array}{l}\text { 2. DATE } \\
08 / 01 / 95\end{array}$ & $\begin{array}{l}\text { 3. IDENTIFICATION NUMBER } \\
\text { DE-ACO5-84OR21400 }\end{array}$ \\
\hline $\begin{array}{l}\text { 4. WBS ELEMENT CODE } \\
\text { 1.6.6.2.10.2.01 ADS OR-6504IS }\end{array}$ & $\begin{array}{l}\text { 5. WBS ELEMENT TITLE } \\
\text { Project Integration }\end{array}$ \\
\hline $\begin{array}{l}\text { 6. INDEX LINE NO. } \\
\text { 7. REVISION NO. AND AUTHORIZATION } \\
0 \quad-\end{array}$ & $\begin{array}{l}\text { 8. DATE } \\
\text { 08/01/95 }\end{array}$ \\
\hline
\end{tabular}

9. APPROVED CHANGES

10. SYSTEM DESIGN DESCRIPTION

11. BUDGET AND REPORTING NUMBER

\section{ELEMENT TASK DESCRIPTION}

\section{OBJECTIVES}

The purpose of Project Integration is to provide project management and develop and to integrate the project plan with the Oak Ridge National Laboratory (ORNL) Decontamination and Decommissioning (D\&D) Baseline.

SCOPE

This project consists of the following activities:

- Project Management - Includes providing the services of a Project Manager and Manager for Planning and Control and their support staff for the duration of the program. Activities include directing, controlling, planning, reporting, and staffing. Additional support for the activities of the ORNL Isotopes Facilities Deactivation Project may be provided by other ORNL divisions, outside subcontractors, or DOE prime contractors.

- Project Plan - Includes the development, update, and periodic revision of the Isotopes Facilities Deactivation Project project plan. Also includes the development and application of the Facility Disposition Decision Model (FDDM) to provide a defensible basis for decisions regarding when, how and to what extent to deactivate surplus federal facilities.

\section{DELIVERABLES}

There are no Level 1 and 2 Milestones schedule during the lifecycle of the project.

\section{PARTICIPANTS}

The primary participants for the following activities are:

Project Management

Project Plan
Lockheed Martin Energy Systems, Inc. (Energy Systems)

Energy Systems 


\section{U. S. DEPARTMENT OF ENERGY \\ WORK BREAKDOWN STRUCTURE DICTIONARY \\ PART II - ELEMENT DEFINITION}

DOE F1332.11

(11-84)

\begin{tabular}{||l|l|l||}
\hline $\begin{array}{l}\text { 1. PROJECT TITLE/PARTICIPANT } \\
\text { ADS OR-6504IS }\end{array}$ & $\begin{array}{l}\text { 2. DATE } \\
08 / 01 / 95\end{array}$ & $\begin{array}{l}\text { 3. IDENTIFICATION NUMBER } \\
\text { DE-ACO5-84OR21400 }\end{array}$ \\
\hline $\begin{array}{l}\text { 4. WBS ELEMENT CODE } \\
\text { 1.6.6.2.10.2.02 ADS OR-6504IS }\end{array}$ & $\begin{array}{l}\text { 5. WBS ELEMENT TTILE } \\
\text { Surveillance and Maintenance }\end{array}$ \\
\hline $\begin{array}{l}\text { 6. INDEX LINE NO. } \\
\text { 7. REVISION NO. AND AUTHORIZATION } \\
0\end{array}$ & $\begin{array}{l}\text { 8. DATE } \\
08 / 01 / 95\end{array}$ \\
\hline
\end{tabular}

9. APPROVED CHANGES

\section{SYSTEM DESIGN DESCRIPTION}

\section{BUDGET AND REPORTING NUMBER}

\section{ELEMENT TASK DESCRIPTION}

\section{OBJECTIVES}

The purpose of this Activity Data Sheet (ADS) is to perform periodic Surveillance and Maintenance (S\&M) of Isotopes Facilities Deactivation Program (IFDP) sites until the commencement of Decontamination and Decommissioning (D\&D) activities.

SCOPE

This Project consists of the following activities:

- Utilities - Activities include the supplying of electrical power, fire protection alarms, heat and ventilation necessary to support the performance of periodic surveillance in each IFDP facility.

- Building 3026 - Activities include weekly surveillance on ventilation system differential pressure, personnel access control; monthly surveillance on grounds housekeeping and exterior signs and restricted area posting/barriers; quarterly surveillance on fire alarm systems, internal and external facility inspections.

- Building 3028 - Activities include weekly surveillance on ventilation system differential pressure, personnel access control; monthly surveillance on grounds housekeeping and exterior signs and restricted area posting/barriers; quarterly surveillance on fire alarm systems, internal and external facility inspections.

- Building 3029 - Activities include weekly surveillance on ventilation system differential pressure, personnel access control; monthly surveillance on grounds housekeeping and exterior signs and restricted area posting/barriers; quarterly surveillance on fire alarm systems, internal and external facility inspections.

- Center Circle Facilities - Activities include weekly surveillance on ventilation system differential pressure, personnel access control; monthly surveillance on grounds housekeeping and exterior signs and restricted area posting/barriers; quarterly surveillance on fire alarm systems, internal and external facility inspections.

- Building 3038 - Activities include weekly surveillance on ventilation system differential pressure, personnel access control; monthly surveillance on grounds housekeeping and exterior signs and restricted area posting/barriers; quarterly surveillance on fire alarm systems, internal and external facility inspections. 


\section{U. S. DEPARTMENT OF ENERGY \\ WORK BREAKDOWN STRUCTURE DICTIONARY \\ PART II - ELEMENT DEFINITION}

DOE F1332.11

$(11-84)$

\begin{tabular}{||l|l|l||}
\hline $\begin{array}{l}\text { 1. PROJECT TITLE/PARTICIPANT } \\
\text { ADS OR-6504IS }\end{array}$ & $\begin{array}{l}\text { 2. DATE } \\
08 / 01 / 95\end{array}$ & $\begin{array}{l}\text { 3. IDENTIFICATION NUMBER } \\
\text { DE-ACO5-84OR21400 }\end{array}$ \\
\hline $\begin{array}{l}\text { 4. WBS ELEMENT CODE } \\
\text { 1.6.6.2.10.2.02 ADS OR-6504IS }\end{array}$ & $\begin{array}{l}\text { 5. WBS ELEMENT TITLE } \\
\text { Surveillance and Maintenance }\end{array}$ \\
\hline
\end{tabular}

\section{ELEMENT TASK DESCRIPTION (continued)}

\section{SCOPE (continued)}

- Building 3047 - Activities include weekly surveillance on ventilation system differential pressure, personnel access control; monthly surveillance on grounds housekeeping and exterior signs and restricted area posting/barriers; quarterly surveillance on fire alarm systems, internal and external facility inspections. Also included is a weekly "walk thru" of the building.

- Building 3517 - Activities include weekly surveillance on ventilation system differential pressure, personnel access control; monthly surveillance on grounds housekeeping and exterior signs and restricted area posting/barriers; quarterly surveillance on fire alarm systems, internal and external facility inspections. Also included is a weekly "walk thru" of the building.

- Building 7025 - Activities include weekly surveillance on ventilation system flow, personnel access control; monthly surveillance on grounds housekeeping and exterior signs and restricted area posting/barriers; quarterly surveillance on fire alarm systems, internal and external facility inspections.

- Other - Activities include the annual inspection of the Actinide Facility (located in Building 9204-3 at Y-12) and the conduct of numerous audits and assessments performed by various organizations both internal and external to Energy Systems.

\section{DELIVERABLES}

There are no Level 1 and 2 Milestones scheduled during the lifecycle of the project.

\section{PARTICIPANTS}

The primary participants for the following activities are:

Surveillance and Maintenance Lockheed Martin Energy Systems, Inc. (Energy Systems)

Utilities

Energy Systems 


\section{U. S. DEPARTMENT OF ENERGY \\ WORK BREAKDOWN STRUCTURE DICTIONARY \\ PART II - ELEMENT DEFINITION}

DOE F1332.11

(11-84)

\begin{tabular}{||l|l|l|l|}
\hline $\begin{array}{l}\text { 1. PROJECT TITLE/PARTICIPANT } \\
\text { ADS OR-6504IS }\end{array}$ & $\begin{array}{l}\text { 2. DATE } \\
08 / 01 / 95\end{array}$ & $\begin{array}{l}\text { 3. IDENTIFICATION NUMBER } \\
\text { DE-ACO5-840R21400 }\end{array}$ \\
\hline $\begin{array}{l}\text { 4. WBS ELEMENT CODE } \\
\text { 1.6.6.2.10.2.04 ADS OR-6504IS }\end{array}$ & $\begin{array}{l}\text { 5. WBS ELEMENT TITLE } \\
\text { Building 3026 Facility Deactivation }\end{array}$ & $\begin{array}{l}\text { 8. DATE } \\
\text { 08/01/95 }\end{array}$ \\
\hline \begin{tabular}{l} 
6. INDEX LINE NO. \\
\hline
\end{tabular} & $\begin{array}{l}\text { 7. REVISION NO. AND AUTHORIZATION } \\
0\end{array}$ & \\
\hline
\end{tabular}

9. APPROVED CHANGES

10. SYSTEM DESIGN DESCRIPTION

11. BUDGET AND REPORTING NUMBER

\section{ELEMENT TASK DESCRIPTION}

\section{OBJECTIVES}

The purpose of the Building 3026 Facility Deactivation is to place Buildings 3026-C and 3026-D in a safe, stable, and environmentally sound condition suitable for an extended period of minimum surveillance and maintenance (S\&M).

SCOPE

This Project consists of the following activities:

- Contamination Control - Includes the removal of residual ${ }^{3} \mathrm{H}$ contamination from labs 7 \& 16 in Building $3026-\mathrm{C}$ and disposal of numerous gas cylinders used in the ${ }^{85} \mathrm{Kr}$ program by venting the cylinders in accordance with allowable release limits, dismantling the valve assemblies and packaging the cylinders as waste. Also included is the deactivation of ${ }^{85} \mathrm{Kr}$ Columns 1 through 4 in Building 3026-C by deactivating all services to the ${ }^{85} \mathrm{Kr}$ thermal diffusion columns, deactivating the cooling tower servicing the columns, disposing of ${ }^{85} \mathrm{Kr}$ contaminated waste, decontaminating all storage tanks, removing all pumps from the storage system and packaging the pumps for disposal as waste, and deactivating all services to the storage system. In the six manipulator hot cells located in Building 3026-D, the irradiated metal specimens will be removed from the cells and transferred to other Oak Ridge National Laboratory (ORNL) facilities; the $\mathrm{Zn}-\mathrm{Br}$ filled shield windows will be drained and the $\mathrm{Zn}-\mathrm{Br}$ disposed as waste. All other waste and loose equipment will be removed from the cells, a general washdown performed, the primary containment of each cell stabilized, each service line to the cells identified, labeled, and plugged, all cell drains plugged, the final radiological condition of each cell documented, and each cell interior access secured.

- Structural Stabilization - Includes the disconnection and draining of all water, air, and gas piping service lines coming into each building. The fire protection wet sprinkler system each building will remain in service. The steam supply shall remain in order to provide minimum heating to prevent the fire suppression systems from freezing. The Building 3026-C chilled water system will be drained, disconnected, and the compressor salvaged. Electrical service not essential to S\&M requirements will be disconnected. All radiation protection instruments and alarms will be removed. Ductwork ventilating Labs 7 and 16 in Building 3026-C will be disconnected and blanked.

- Radioluminescent (RL) Lights Removal - Includes the inventory, disassembly and packaging and transport of numerous ${ }^{3} \mathrm{H}$ filled RL lights located in Building 3026-C into Type A containers suitable for transfer off-site, or packaged and managed as solid low level radioactive waste. 


\begin{tabular}{||l|l|l||}
\hline $\begin{array}{l}\text { 1. PROJECT TITLE/PARTICIPANT } \\
\text { ADS OR-6504IS }\end{array}$ & $\begin{array}{l}\text { 2. DATE } \\
08 / 01 / 95\end{array}$ & $\begin{array}{l}\text { 3. IDENTIFICATION NUMBER } \\
\text { DE-ACO5-84OR21400 }\end{array}$ \\
\hline $\begin{array}{l}\text { 4. WBS ELEMENT CODE } \\
\text { 1.6.6.2.10.2.04 ADS OR-6504IS }\end{array}$ & $\begin{array}{l}\text { 5. WBS ELEMENT TITLE } \\
\text { Building 3026 Facility Deactivation }\end{array}$ \\
\hline
\end{tabular}

\section{ELEMENT TASK DESCRIPTION (continued)}

SCOPE (continued)

- Final Facility Report - Includes preparation of a report providing documentation of the history, physical and radiological condition of the facility, as-is drawings of essential facility support systems, and S\&M requirements and procedures.

\section{DELIVERABLES}

The following Level 1 and 2 Milestones will be performed during the lifecycle of the project:

Building 3026-C Deactivation Complete

Building 3026-D Deactivation Complete

\section{PARTICIPANTS}

The primary participants for the following activities are:

Maintenance

Construction

Contamination Control

Final Decontamination Inventory Reduction
Lockheed Martin Energy Systems, Inc. (Energy Systems)

DOE Prime Construction Contractor or Energy Systems Subcontractor

Energy Systems, Subcontractor

Energy Systems, Subcontractor

Energy Systems, Subcontractor 


\section{U. S. DEPARTMENT OF ENERGY \\ WORK BREAKDOWN STRUCTURE DICTIONARY \\ PART II - ELEMENT DEFINITION}

DOE F1332.11

$(11-84)$

\begin{tabular}{|l|l|l|l|}
\hline $\begin{array}{l}\text { 1. PROJECT TITLE/PARTICIPANT } \\
\text { ADS OR-6504IS }\end{array}$ & $\begin{array}{l}\text { 2. DATE } \\
08 / 01 / 95\end{array}$ & $\begin{array}{l}\text { 3. IDENTIFICATION NUMBER } \\
\text { DE-ACO5-84OR21400 }\end{array}$ \\
\hline $\begin{array}{l}\text { 4. WBS ELEMENT CODE } \\
1.6 .6 .2 .10 .2 .06 \text { ADS OR-6504IS }\end{array}$ & $\begin{array}{l}\text { 5. WBS ELEMENT TITLE } \\
\text { Building 3028 Facility Deactivation }\end{array}$ \\
\hline $\begin{array}{l}\text { 6. INDEX LINE NO. } \\
\text { 7. REVISION NO. AND AUTHORIZATION } \\
0\end{array}$ & $\begin{array}{l}\text { 8. DATE } \\
\text { 08/01/95 }\end{array}$ \\
\hline 9. APPROVED CHANGES & 11. BUDGET AND REPORTING NUMBER \\
\hline 10. SYSTEM DESIGN DESCRIPTION
\end{tabular}

\section{ELEMENT TASK DESCRIPTION}

\section{OBJECTIVES}

The purpose of the Building 3028 Facility Deactivation is to place Building 3028 in a safe, stable, and environmentally sound condition suitable for an extended period of minimum surveillance and maintenance (S\&M).

SCOPE

This project consists of the following activities:

- Contamination Control - Includes the deactivation of seven highly contaminated hot cells. All waste and loose equipment will be removed from the cells, a general washdown performed, the primary containment of each cell stabilized, each service line to the cells identified, labeled, and plugged, each manipulator boot and in-cell filter replaced, all cell drains plugged, the final radiological condition of each cell documented, and the cell interior access secured. The water-filled shielding tanks in front of Cells 1 through 5 will be drained and the chilled water system associated with these shielding tanks will be deactivated. The charging area behind Cells 1 through 5 will also be cleaned to remove potential airborne contamination.

- Structural Stabilization - Includes the disconnection and draining of all water, air, steam, and gas piping service lines coming into each building. The fire protection wet sprinkler system will be converted to a manually activated dry system. Electrical service not essential to S\&M requirements will be disconnected. All radiation protection instruments and alarms will be removed. The exterior of the building will also be sealed.

- Final Facility Report - Includes preparation of a report providing documentation of the history, physical and radiological condition of the facility, as-is drawings of essential facility support systems, and S\&M requirements and procedures. 
DEPARTMENT OF ENERGY

WORK BREAKDOWN STRUCTURE DICTIONARY

PART II - ELEMENT DEFINITION

DOE F 1332.11

(11-84)

\begin{tabular}{||l|l|l||}
\hline $\begin{array}{l}\text { 1. PROJECT TITLE/PARTICIPANT } \\
\text { ADS OR-6504IS }\end{array}$ & $\begin{array}{l}\text { 2. DATE } \\
08 / 01 / 95\end{array}$ & $\begin{array}{l}\text { 3. DENTIFICATION NUMBER } \\
\text { DE-ACO5-84OR21400 }\end{array}$ \\
\hline $\begin{array}{l}\text { 4. WBS ELEMENT CODE } \\
\text { 1.6.6.2.10.2.06 ADS OR-6504IS }\end{array}$ & $\begin{array}{l}\text { 5. WBS ELEMENT TITLE } \\
\text { Building 3028 Facility Deactivation }\end{array}$ \\
\hline
\end{tabular}

12. ELEMENT TASK DESCRIPTION (continued)

\section{DELIVERABLES}

The following Level 1 and 2 Milestones will be performed during the lifecycle of the project:

Building 3028 Deactivation Complete

\section{PARTICIPANTS}

The primary participants for the following activities are:

Construction

Structural Stabilization

Final Facility Report
DOE Prime Construction Contractor, Subcontractor

Lockheed Martin Energy Systems, Inc. (Energy Systems)

Energy Systems Subcontractor 
U. S. DEPARTMENT OF ENERGY

WORK BREAKDOWN STRUCTURE DICTIONARY

PART II - ELEMENT DEFINITION

DOE F 1332.11

(11-84)

\begin{tabular}{||l|l|l|l|}
\hline $\begin{array}{l}\text { 1. PROJECT TITLE/PARTICIPANT } \\
\text { ADS OR-6504IS }\end{array}$ & $\begin{array}{l}\text { 2. DATE } \\
08 / 01 / 95\end{array}$ & $\begin{array}{l}\text { 3. IDENTIFICATION NUMBER } \\
\text { DE-ACO5-840R21400 }\end{array}$ \\
\hline $\begin{array}{l}\text { 4. WBS ELEMENT CODE } \\
\text { 1.6.6.2.10.2.08 ADS OR-6504IS }\end{array}$ & $\begin{array}{l}\text { 5. WBS ELEMENT TITLE } \\
\text { Building 3029 Facility Deactivation }\end{array}$ \\
\hline $\begin{array}{l}\text { 6. INDEX LINE NO. } \\
\text { 7. REVISION NO. AND AUTHORIZATION } \\
0\end{array}$ & $\begin{array}{l}\text { 8. DATE } \\
\text { 08/01/95 }\end{array}$ \\
\hline
\end{tabular}

9. APPROVED CHANGES

10. SYSTEM DESIGN DESCRIPTION

11. BUDGET AND REPORTING NUMBER

\section{ELEMENT TASK DESCRIPTION}

\section{OBJECTIVES}

The purpose of the Building 3029 Facility Deactivation is to place Building 3029 in a safe, stable, and environmentally sound condition suitable for an extended period of minimum surveillance and maintenance (S\&M).

SCOPE

This project consists of the following activities:

- Contamination Control - Includes the deactivation of four manipulator hot cells and four glove boxes. For each of the hot cells, the waste and loose equipment will be removed from the cells, a general washdown performed, the primary containment of each cell stabilized, each service line to the cells identified, labeled, and plugged, each manipulator boot and in-cell filter replaced, all cell drains plugged, the final radiological condition of each cell documented, and the cell interior access secured. The two ${ }^{131} \mathrm{I}$ glove boxes will be cleaned, sealed and left in the building. The ${ }^{14} \mathrm{C}$ and ${ }^{99} \mathrm{~T}$ glove boxes will be removed and managed as Solid Low Level Waste (SLLW).

- Structural Stabilization - Includes the disconnection and draining of all water, air, steam, and gas piping service lines coming into each building. The fire protection wet sprinkler system will be converted to a manually activated dry system. Electrical service not essential to S\&M requirements will be disconnected. All radiation protection instruments and alarms will be removed. The exterior of the building will also be sealed.

- Final Facility Report - Includes preparation of a report providing documentation of the history, physical and radiological condition of the facility, as-is drawings of essential facility support systems, and $S \& M$ requirements and procedures. 
DEPARTMENT OF ENERGY

WORK BREAKDOWN STRUCTURE DICTIONARY

PART II - ELEMENT DEFINITION

DOE F1332.11

(11-84)

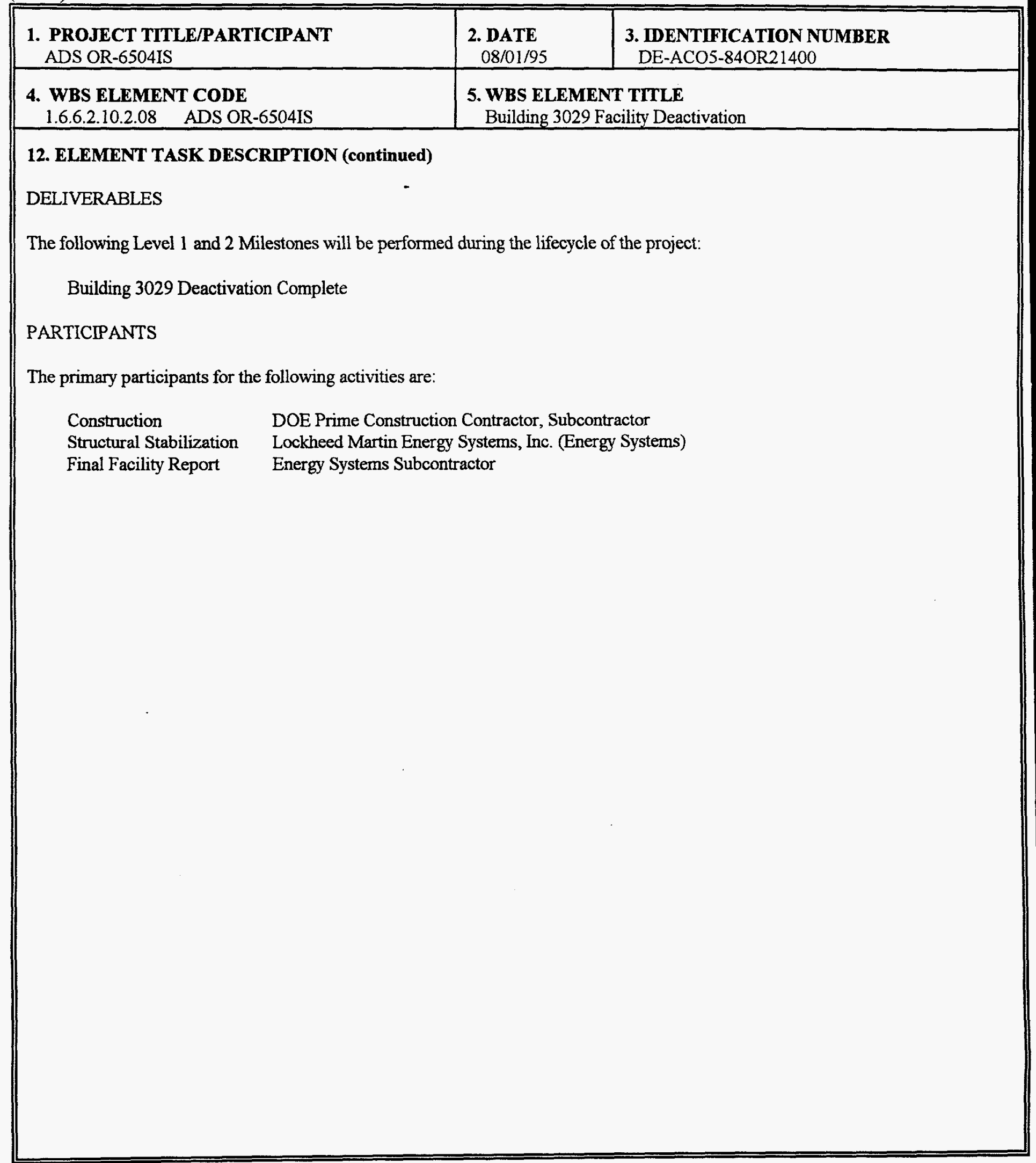




\section{U. S. DEPARTMENT OF ENERGY \\ WORK BREAKDOWN STRUCTURE DICTIONARY \\ PART II - ELEMENT DEFINITION}

DOE F 1332.11

(11-84)

\begin{tabular}{||l|l|l|l|}
\hline $\begin{array}{l}\text { 1. PROJECT TITLE/PARTICIPANT } \\
\text { ADS OR-6504IS }\end{array}$ & $\begin{array}{l}\text { 2. DATE } \\
08 / 01 / 95\end{array}$ & $\begin{array}{l}\text { 3. IDENTIFICATION NUMBER } \\
\text { DE-ACO5-84OR21400 }\end{array}$ \\
\hline $\begin{array}{l}\text { 4. WBS ELEMENT CODE } \\
1.6 .6 .2 .10 .2 .10 \text { ADS OR-6504IS }\end{array}$ & $\begin{array}{l}\text { 5. WBS ELEMENT TITLE } \\
\text { Center Circle Facility }(3030-3034,3118) \text { Deactivation }\end{array}$ \\
\hline $\begin{array}{l}\text { 6. INDEX LINE NO. } \\
\text { 7. REVISION NO. AND AUTHORIZATION } \\
0\end{array}$ & $\begin{array}{l}\text { 8. DATE } \\
\text { 08/01/95 }\end{array}$ \\
\hline
\end{tabular}

9. APPROVED CHANGES

10. SYSTEM DESIGN DESCRIPTION

11. BUDGET AND REPORTING NUMBER

\section{ELEMENT TASK DESCRIPTION}

\section{OBJECTIVES}

The purpose of the Center Circle Facility Deactivation Project is to place Buildings 3030, 3031, 3032, 3033, 3033-A, 3118 , and 3034 in a safe, stable, and environmentally sound condition suitable for an extended period of minimum surveillance and maintenance (S\&M).

SCOPE

This project consists of the following activities:

- Contamination Control - Includes deactivation of hot cells in Buildings 3030, and 3031. For each of the hot cells, the waste and loose equipment will be removed from the cells, a general washdown performed, the primary containment of each cell stabilized, each service line to the cells identified, labeled, and plugged, all cell drains plugged, the final radiological condition of each cell documented, and the cell interior access secured.

The ${ }^{3} \mathrm{H}$ system in Building 3033 will be deactivated. The ${ }^{3} \mathrm{H}$ traps will be inerted, removed from the ${ }^{3} \mathrm{H}$ processing system, and packaged for disposal. The ${ }^{3} \mathrm{H}$ processing hood will be cleaned and all hood support systems will be labeled and deactivated. The ${ }^{85} \mathrm{Kr}$ purification system in the building will also be deactivated. The charcoal traps and roughing pumps from the ${ }^{85} \mathrm{Kr}$ processing system will be removed, packaged, and disposed of as waste.

All contamination control activities have been completed in Building 3033-A.

The five hoods in Building 3034 will be disconnected and removed from the building.

- Structural Stabilization - Includes the disconnection and draining of all water, air, steam, and gas piping service lines coming into Building 3030 and 3031 . Electrical service not essential to S\&M requirements will be disconnected. All radiation protection instruments and alarms will be removed. The roof of Building 3033-A is to be repaired and the exteriors of Buildings 3030 and 3033 will be sealed.

Buildings 3032 and 3034 will remain occupied following deactivation until all IFDP facilities are transfered to the D\&D Program. Utility services will remain connected to these buildings until transfer to D\&D ownership. 
DEPARTMENT OF ENERGY

WORK BREAKDOWN STRUCTURE DICTIONARY

PART II - ELEMENT DEFINITION

DOE F1332.11

$(11-84)$

\begin{tabular}{||l|l|l||}
\hline $\begin{array}{l}\text { 1. PROJECT TITLE/PARTICIPANT } \\
\text { ADS OR-6504IS }\end{array}$ & $\begin{array}{l}\text { 2. DATE } \\
08 / 01 / 95\end{array}$ & $\begin{array}{l}\text { 3. IDENTIFICATION NUMBER } \\
\text { DE-ACO5-84OR21400 }\end{array}$ \\
\hline $\begin{array}{l}\text { 4. WBS ELEMENT CODE } \\
1.6 .6 .2 .10 .2 .10 \text { ADS OR-6504IS }\end{array}$ & $\begin{array}{l}\text { 5. WBS ELEMENT TITLE } \\
\text { Center Circle Facility Deactivation }\end{array}$ \\
\hline
\end{tabular}

\section{ELEMENT TASK DESCRIPTION (continued)}

SCOPE (continued)

- Re-Roof Buildings 3030, 3118, 3031 - Includes activities to re-roof the complex consisting of Buildings 3030, 3118 , and 3031 .

- Final Facility Report - Includes preparation of a report providing documentation of the history, physical and radiological condition of each of the buildings, as-is drawings of essential facility support systems, and S\&M requirements and procedures.

DELIVERABLES

The following Level 1 and 2 Milestones will be performed during the lifecycle of the project:

Building 3030 Building Deactivation Complete

Building 3031 Building Deactivation Complete

Building 3032 Building Deactivation Complete

Building 3033-A Building Deactivation Complete

Building 3033 Building Deactivation Complete

Building 3034 Building Deactivation Complete

Building 3118 Building Deactivation Complete

\section{PARTICIPANTS}

The primary participants for the following activities are:

Construction

Structural Stabilization

Final Facility Report
DOE Prime Construction Contractor, Subcontractor

Lockheed Martin Energy Systems, Inc. (Energy Systems)

Energy Systems Subcontractor 


\section{U. S. DEPARTMENT OF ENERGY \\ WORK BREAKDOWN STRUCTURE DICTIONARY \\ PART II - ELEMENT DEFINITION}

DOE F 1332.11

(11-84)

\begin{tabular}{||l|l|l||}
\hline $\begin{array}{l}\text { 1. PROJECT TITLEPARTICIPANT } \\
\text { ADS OR-6504IS }\end{array}$ & $\begin{array}{l}\text { 2. DATE } \\
08 / 01 / 95\end{array}$ & $\begin{array}{l}\text { 3. IDENTIFICATION NUMBER } \\
\text { DE-ACO5-84OR21400 }\end{array}$ \\
\hline $\begin{array}{l}\text { 4. WBS ELEMENT CODE } \\
1.6 .6 .2 .10 .2 .12 \text { ADS OR-6504IS }\end{array}$ & $\begin{array}{l}\text { 5. WBS ELEMENT TITLE } \\
\text { Building 3038 Facility Deactivation }\end{array}$ & $\begin{array}{c}\text { 8. DATE } \\
08 / 01 / 95\end{array}$ \\
\hline \begin{tabular}{l} 
6. INDEX LINE NO. \\
\hline
\end{tabular} & $\begin{array}{l}\text { 7. REVISION NO. AND AUTHORIZATION } \\
0\end{array}$ & \\
\hline
\end{tabular}

\section{APPROVED CHANGES}

10. SYSTEM DESIGN DESCRIPTION

11. BUDGET AND REPORTING NUMBER

\section{ELEMENT TASK DESCRIPTION}

\section{OBJECTIVES}

The purpose of the Building 3038 Facility Deactivation Project is to place the facility (which Buildings 3038-Alpha Handling Facility (AHF), 3038-E, and 3038-M) in a safe, stable, and environmentally sound condition suitable for an extended period of minimum surveillance and maintenance (S\&M).

SCOPE

This project consists of the following activities:

- Contamination Control - Includes the deactivation of five hot cells in Building 3038-AHF. For each of the hot cells, the waste and loose equipment will be removed from the cells, a general washdown performed, the primary containment of each cell stabilized, each service line to the cells identified, labeled, and plugged, all cell drains plugged, the final radiological condition of each cell documented, and the cell interior access secured. The water-filled shielding tanks in front of the hot cells will be drained and the chilled water system associated with these shield tanks will be deactivated. The operating area in front of the hot cells will be cleane to remove potential airborne contamination.

- Structurai Stabilization - Includes repairs to the drains in Building 3038-AHF which have been sealed to prevent use due to leaks in the underground transfer lines, converting the Building 3038-AHF fire detection system to a manually activated dry system, and the disconnection and draining of all water, air, steam, and gas piping service lines coming into Buildings 3038-E and 3038-M. Electrical service not essential to $S \& M$ requirements will be disconnected. All radiation protection instruments and alarms in Buildings 3038-E and 3038-M will be removed.

- Yttrium Cell Cleanup - Includes removing the waste and loose equipment will be removed from the Yttrium cell in Building 3038-E. A general wipedown will be performed, the primary containment of stabilized, each service line to the cells identified, labeled, and plugged, the final radiological condition of the cell documented, and the cell interior access secured. 


\section{DEPARTMENT OF ENERGY \\ WORK BREAKDOWN STRUCTURE DICTIONARY \\ PART II - ELEMENT DEFINITION}

DOEF1332.11

$(11-84)$

\begin{tabular}{||l|l|l||}
\hline $\begin{array}{l}\text { 1. PROJECT TITLE/PARTICIPANT } \\
\text { ADS OR-6504IS }\end{array}$ & $\begin{array}{l}\text { 2. DATE } \\
08 / 01 / 95\end{array}$ & $\begin{array}{l}\text { 3. IDENTIFICATION NUMBER } \\
\text { DE-ACO5-84OR21400 }\end{array}$ \\
\hline $\begin{array}{l}\text { 4. WBS ELEMENT CODE } \\
1.6 .6 .2 .10 .2 .12 \quad \text { ADS OR-6504IS }\end{array}$ & $\begin{array}{l}\text { 5. WBS ELEMENT TITLE } \\
\text { Building 3038 Facility Deactivation }\end{array}$ \\
\hline
\end{tabular}

\section{ELEMENT TASK DESCRIPTION (continued)}

SCOPE (continued)

- Glove Box \& Hoods Deactivation - Includes deactivation of the seven glove boxes in Building 3038-AHF and the eleven glove boxes and eight hoods in Building 3038-E. The rolling mill box in the north lab and two inert glove boxes in the south lab of Building 3038-E will be cleaned to remove all transferable contamination from their interior, painted to bond any fixed contamination, and all ports sealed. All service piping and drains will be disconnected and sealed. The hoods will be wiped down to remove transferrable contamination, liquid low-level (radioactive) waste (LLLW) drains will be plugged, and the hood locked and tagged out-of-service. All utility services to the hoods will be disconnected.

- Barricade Cleanup - Includes the deactivation of the barricade in Building 3038-M. All waste from the barricade area will be removed, the area cleaned, and all service lines to the barricade will be deactivated. Access to the barricade will be secured.

- Final Facility Report - Includes preparation of a report providing documentation of the history, physical and radiological condition of each of the buildings, as-is drawings of essential facility support systems, and S\&M requirements and procedures.

\section{DELIVERABLES}

The following Level 1 and 2 Milestones will be performed during the lifecycle of the project:

Building 3038-E Building Deactivation Complete

Building 3038-M Building Deactivation Complete

Building 3038-AHF Building Deactivation Complete

\section{PARTICIPANTS}

The primary participants for the following activities are:

Construction

Structural Stabilization

Final Facility Report
DOE Prime Construction Contractor, Subcontractor

Lockheed Martin Energy Systems, Inc. (Energy Systems)

Energy Systems Subcontractor 


\begin{tabular}{||l|l|l|l|}
\hline $\begin{array}{l}\text { 1. PROJECT TITLE/PARTICIPANT } \\
\text { ADS OR-6504IS }\end{array}$ & $\begin{array}{l}\text { 2. DATE } \\
08 / 01 / 95\end{array}$ & $\begin{array}{l}\text { 3. IDENTIFICATION NUMBER } \\
\text { DE-ACO5-84OR21400 }\end{array}$ \\
\hline $\begin{array}{l}\text { 4. WBS ELEMENT CODE } \\
\text { 1.6.6.2.10.2.14 ADS OR-6504IS }\end{array}$ & $\begin{array}{l}\text { 5. WBS ELEMENT TITLE } \\
\text { Building 3047 Facility Deactivation }\end{array}$ \\
\hline 6. INDEX LINE NO. & $\begin{array}{l}\text { 7. REVISION NO. AND AUTHORIZATION } \\
0\end{array}$ & $\begin{array}{l}\text { 8. DATE } \\
08 / 01 / 95\end{array}$ \\
\hline
\end{tabular}

\section{APPROVED CHANGES}

\section{ELEMENT TASK DESCRIPTION}

\section{OBJECTIVES}

The purpose of the Building 3047 Facility Deactivation Project is to place Building 3047 in a safe, stable, and environmentally sound condition suitable for an extended period of minimum surveillance and maintenance (S\&M).

SCOPE

This project consists of the following activities:

- Contamination Control - Includes clean up of the vacuum pit, decontamination of the vacuum system surge tank, and cleanup of the filter house. Pieces of contaminated, high-efficiency particulate air filter media that are lodged on the control damper to the filter house in the west airlock will be removed.

- Structural Stabilization - Includes deactivation of the building chilled water system, converting the fire protection system to a manually activated dry system, and the disconnection and draining of all water, air, steam, and gas piping service lines coming into the building. Electrical service not essential to S\&M requirements will be disconnected. All radiation protection instruments and alarms in the building will be removed. The chilled water system will be drained, pipes and electrical services disconnected, and the pumps salvaged.

- Hot Cells Cleanup - Includes the deactivation of Hot Cells A, B, C, D and the alpha cell in Room 110. All waste and loose equipment will be removed from the cells. A general washdown will be performed, the primary containment of each cell stabilized, each service line to the cells identified, labeled, and plugged, all cell drains plugged, the final radiological condition of the cell documented, and each cell interior access secured. The sludge in the sump under Cell D will also be removed.

- Glove Boxes \& Hoods Removal - Includes the deactivation and removal of the gadolinium press box and ${ }^{14} \mathrm{C}$ glove boxes. All services will be disconnected and the box interiors cleaned and fixed with a sealant. The hoods in Rooms 105, 109, 208, 209, and 210 will be wiped down to remove transferrable contamination, liquid low-level (radioactive) waste (LLLW) drains will be plugged, and the hood locked and tagged out-of-service. All utility services to the hoods will be disconnected.

- Final Facility Report - Includes preparation of a report providing documentation of the history, physical and radiological condition of each of the buildings, as-is drawings of essential facility support systems, and S\&M requirements and procedures. 
DEPARTMENT OF ENERGY

WORK BREAKDOWN STRUCTURE DICTIONARY

PART II - ELEMENT DEFINITION

DOE F 1332.11

$(11-84)$

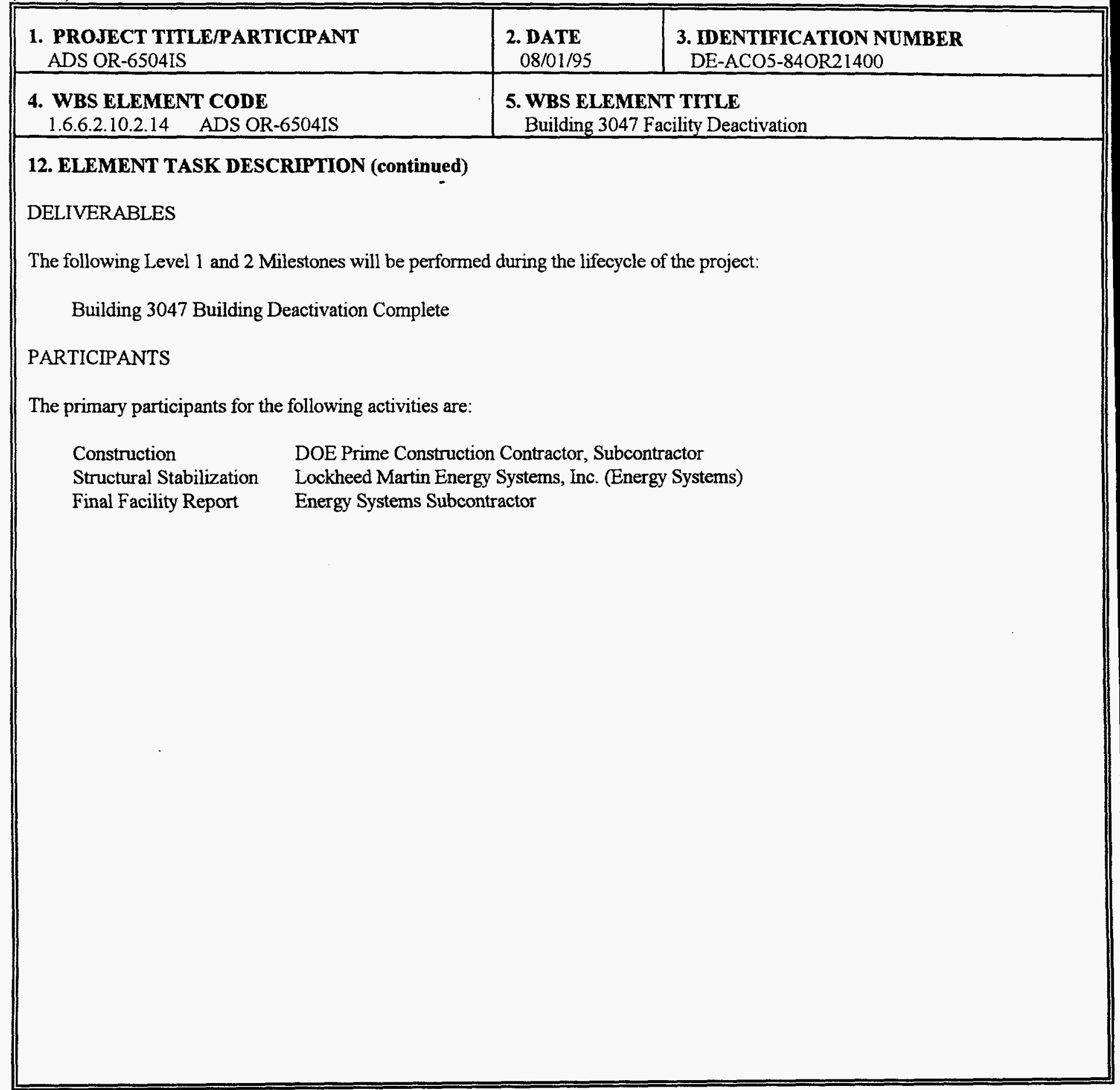




\section{U. S. DEPARTMENT OF ENERGY \\ WORK BREAKDOWN STRUCTURE DICTIONARY \\ PART II - ELEMENT DEFINITION}

DOE F1332.11

(11-84)

\begin{tabular}{||l|l|l|l|}
\hline $\begin{array}{l}\text { 1. PROJECT TITLE/PARTICIPANT } \\
\text { ADS OR-6504IS }\end{array}$ & $\begin{array}{l}\text { 2. DATE } \\
08 / 01 / 95\end{array}$ & $\begin{array}{l}\text { 3. IDENTIFICATION NUMBER } \\
\text { DE-ACO5-84OR21400 }\end{array}$ \\
\hline $\begin{array}{l}\text { 4. WBS ELEMENT CODE } \\
\text { 1.6.6.2.10.2.16 ADS OR-6504IS }\end{array}$ & $\begin{array}{l}\text { 5. WBS ELEMENT TITLE } \\
\text { Building 3517 Facility Deactivation }\end{array}$ \\
\hline $\begin{array}{l}\text { 6. INDEX LINE NO. } \\
\text { 7. REVISION NO. AND AUTHORIZATION } \\
0\end{array}$ & $\begin{array}{l}\text { 8. DATE } \\
\text { 08/01/95 }\end{array}$ \\
\hline
\end{tabular}

\section{APPROVED CHANGES}

\section{SYSTEM DESIGN DESCRIPTION}

\section{ELEMENT TASK DESCRIPTION}

\section{OBJECTIVES}

The purpose of the Building 3517 Facility Deactivation Project is to place Building 3517 in a safe, stable, and environmentally sound condition suitable for an extended period of minimum surveillance and maintenance (S\&M).

\section{SCOPE}

This project consists of the following activities:

- Structural Stabilization - Includes conversion of the fire protection system to a manually activated dry system and the disconnection and draining of all water, air, steam, and gas piping service lines coming into the building. Electrical service not essential to S\&M requirements will be disconnected. All radiation protection instruments and alarms in the building will be removed.

- Hot Cells Cleanup - Includes the deactivation of cells 10,11,12,13,14,15,16, and 18. All waste and loose equipment will be removed from the cells. A general washdown will be performed, the primary containment of each cell stabilized, each service line to the cells identified, labeled, and plugged, all cell drains plugged, the final radiological condition of the cell documented, and each cell interior access secured.

- Inventory Transfer - Includes transferring seventeen containers of ${ }^{244} \mathrm{Cm}$ to the Chemical Engineering Development Center at the Oak Ridge National Laboratory (ORNL), repackaging Eu and Gd materials for retrievable storage and transferring the materials to the solid waste storage area, repackaging all ${ }^{137} \mathrm{Cs}$ and ${ }^{90} \mathrm{Sr}$ sources to meet Waste Encapsulation Storage Facility (WESF) criteria and transferring the sources to WESF. Once waste acceptance criteria have been received from WESF, repackaging requirements and the extent of process operation that must be resumed to perform repackaging operations will be determined and the options of using Building 3517 or some other ORNL facility will be evaluated. If the use of Building 3517 is evaluated as the best option, a justification for resumption of repackaging operation will be prepared and all necessary physical upgrades to the facility to resume source repackaging operations will be performed. 
DEPARTMENT OF ENERGY

WORK BREAKDOWN STRUCTURE DICTIONARY

PART II - ELEMENT DEFINITION

DOE F1332.11

(11-84)

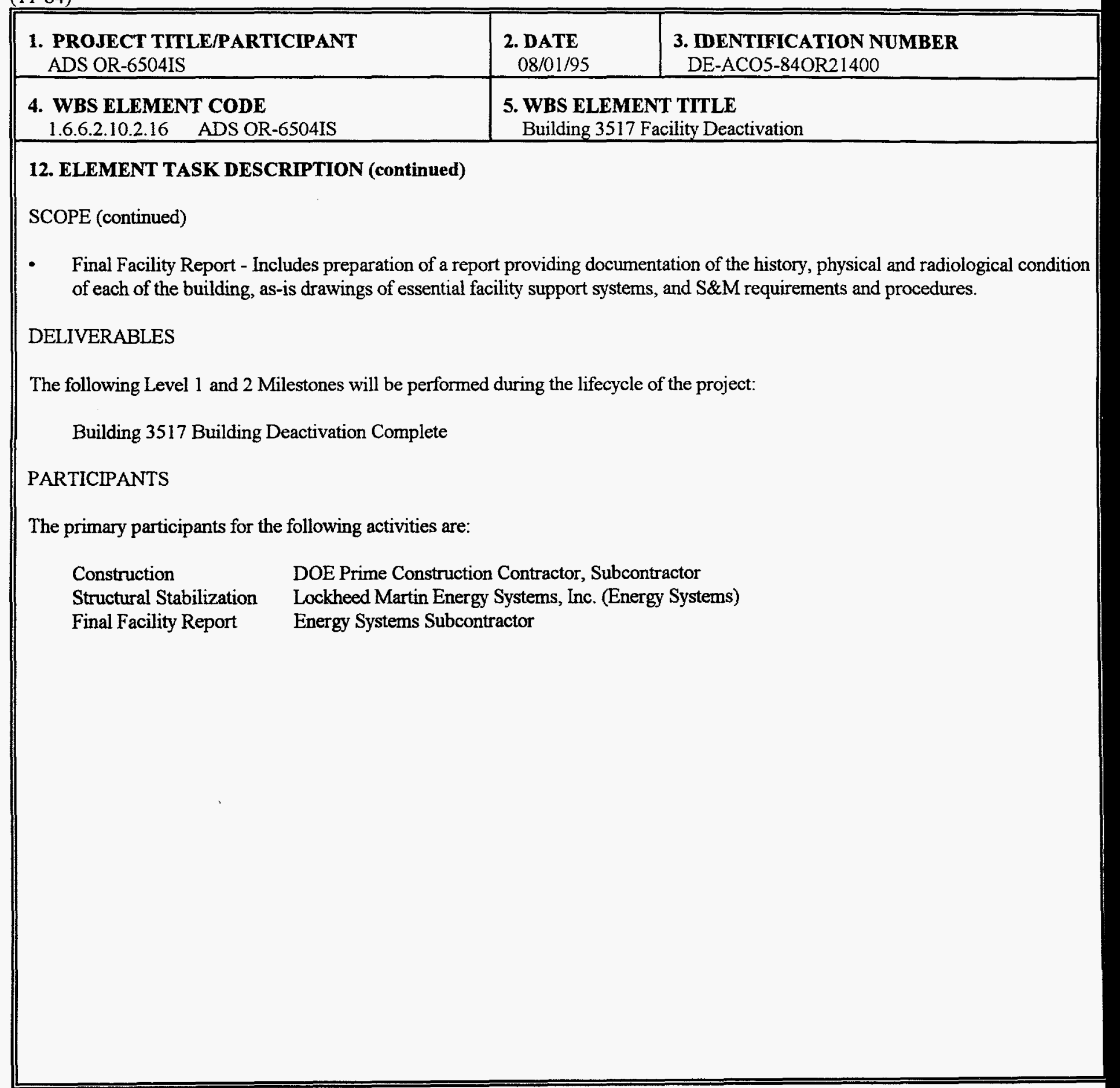


U. S. DEPARTMENT OF ENERGY

WORK BREAKDOWN STRUCTURE DICTIONARY

PART II - ELEMENT DEFINITION

DOE F 1332.11

$(11-84)$

\begin{tabular}{||l|l|l|l|}
\hline $\begin{array}{l}\text { 1. PROJECT TITLE/PARTICIPANT } \\
\text { ADS OR-6504IS }\end{array}$ & $\begin{array}{l}\text { 2. DATE } \\
08 / 01 / 95\end{array}$ & $\begin{array}{l}\text { 3. IENTIFICATION NUMBER } \\
\text { DE-ACO5-84OR21400 }\end{array}$ \\
\hline $\begin{array}{l}\text { 4. WBS ELEMENT CODE } \\
\text { 1.6.6.2.10.2.18 ADS OR-6504IS }\end{array}$ & $\begin{array}{l}\text { 5. WBS ELEMENT TITLE } \\
\text { Building 7025 Facility Deactivation }\end{array}$ \\
\hline $\begin{array}{l}\text { 6. INDEX LINE NO. } \\
\text { 7. REVISION NO. AND AUTHORIZATION } \\
0\end{array}$ & $\begin{array}{l}\text { 8. DATE } \\
\text { 08/01/95 }\end{array}$ \\
\hline
\end{tabular}

\section{APPROVED CHANGES}

10. SYSTEM DESIGN DESCRIPTION

11. BUDGET AND REPORTING NUMBER

\section{ELEMENT TASK DESCRIPTION}

\section{OBJECTIVES}

The purpose of the Building 7025 Facility Deactivation Project is to place Building 7025 in a safe, stable, and environmentally sound condition suitable for an extended period of minimum surveillance and maintenance (S\&M).

SCOPE

This project consists of the following activities:

- Contamination Control - Includes deactivation of the ${ }^{3} \mathrm{H}$ target fabrication system which houses the fabrication system. All waste will be removed and the hood cleaned.

- Structural Stabilization - Includes the disconnection and draining of all water, air, steam, and gas piping service lines coming into the building. Electrical service not essential to $\mathrm{S} \& \mathrm{M}$ requirements will be disconnected. All radiation protection instruments and alarms in the building will be removed.

- Final Fs sility Report - Includes preparation of a report providing documentation of the history, physical and radiological condition of eas the building, as-is drawings of essential facility support systems, and S\&M requirements and procedures.

\section{DELIVERAOSLES}

The following Level 1 and 2 Milestones will be performed during the lifecycle of the project:

Building 7025 Building Deactivation Complete

\section{PARTICIPANTS}

The primary participants for the following activities are:

Construction

Structural Stabilization

Final Facility Report
DOE Prime Construction Contractor, Subcontractor Lockheed Martin Energy Systems, Inc. (Energy Systems)

Energy Systems Subcontractor 
U. S. DEPARTMENT OF ENERGY

WORK BREAKDOWN STRUCTURE DICTIONARY

PART II - ELEMENT DEFINITION

DOE F1332.11

(11-84)

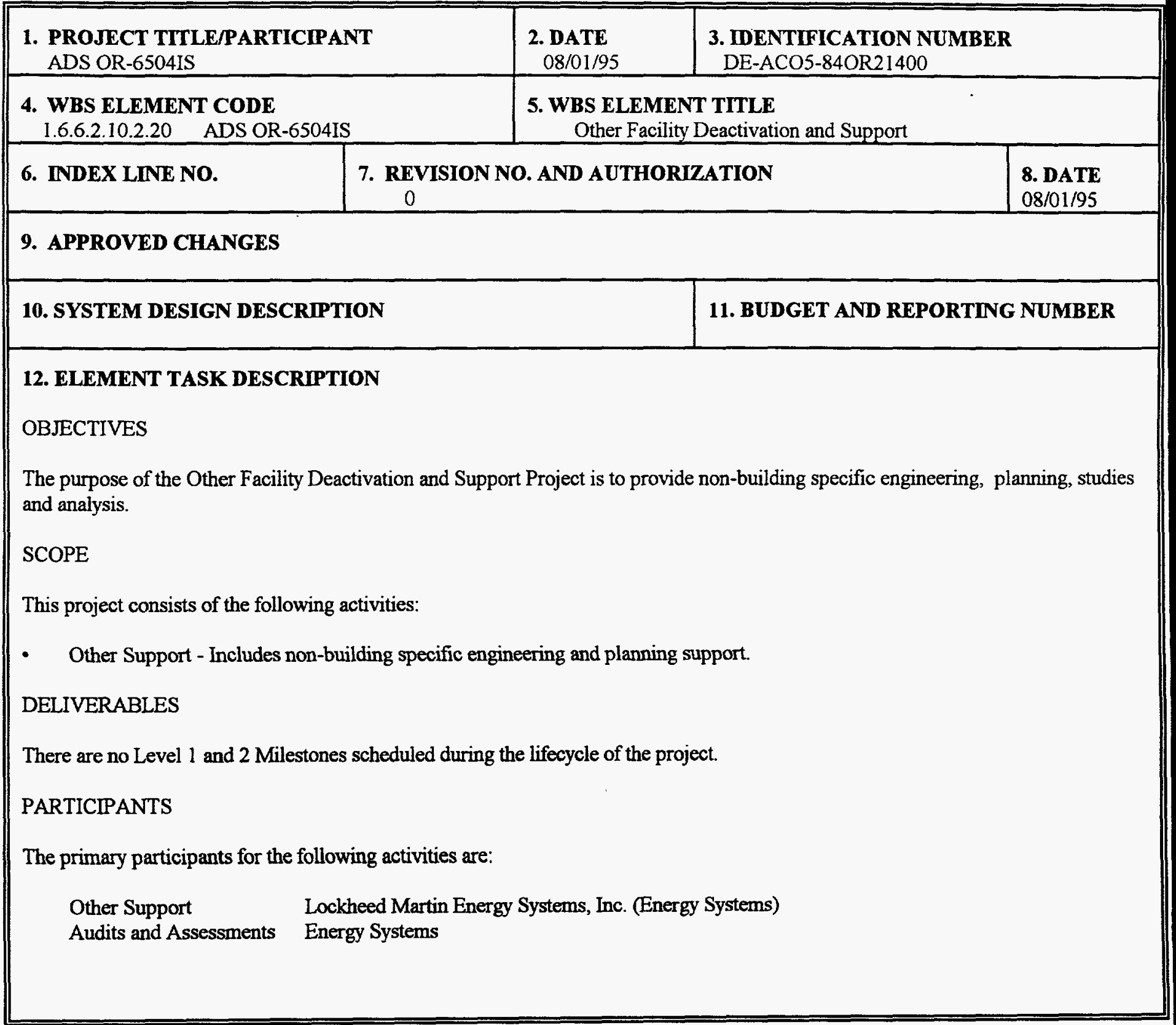




\subsection{ADS OR-6504IS SCHEDULE SUMMARY}

The following section contains the schedule summaries for ADS OR-6504IS. The project gantt charts and milesione schedules are shown in Fig. 3.2. 


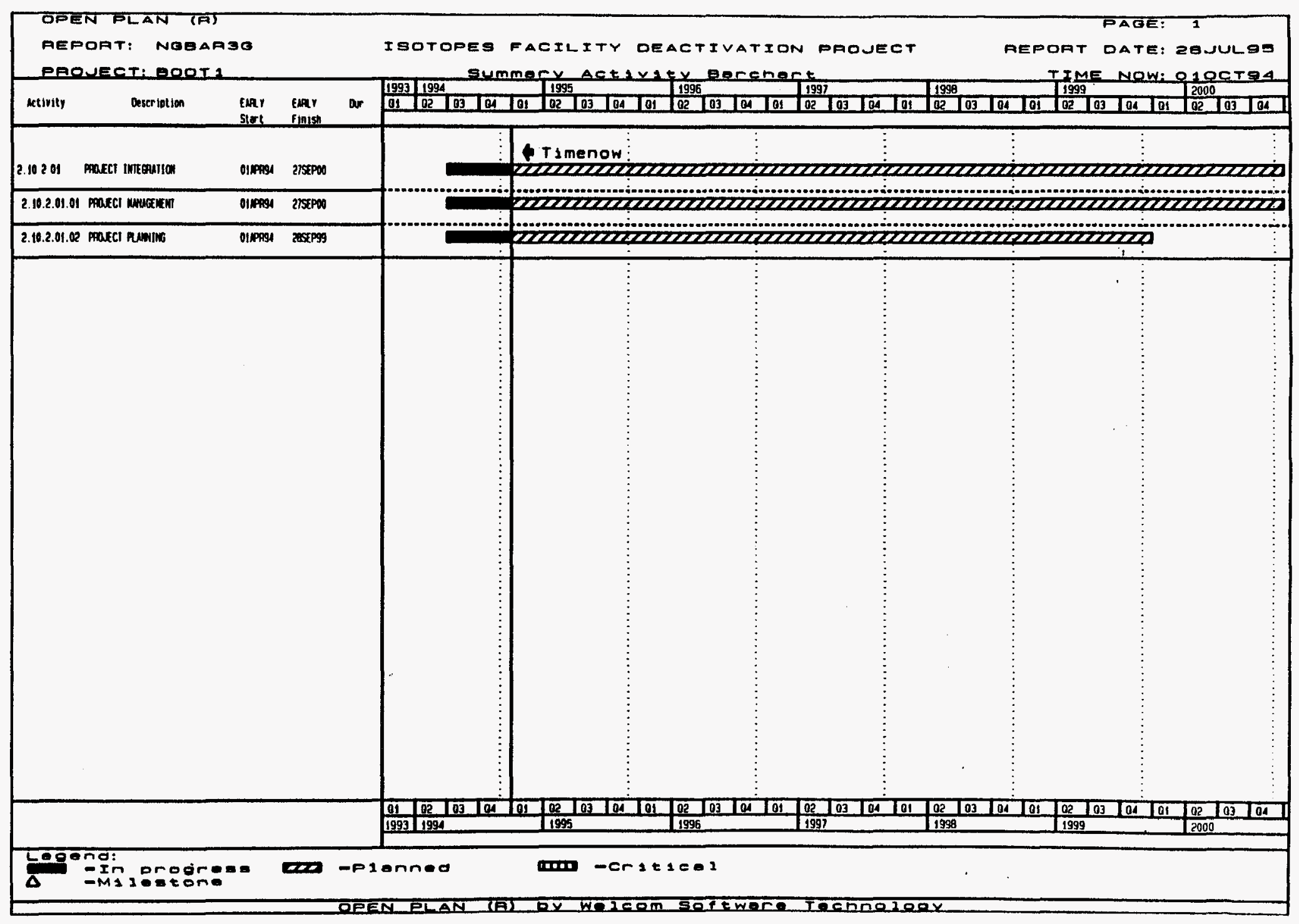

Fig. 3.2. Gantt charts and milestone schedules. 
를 


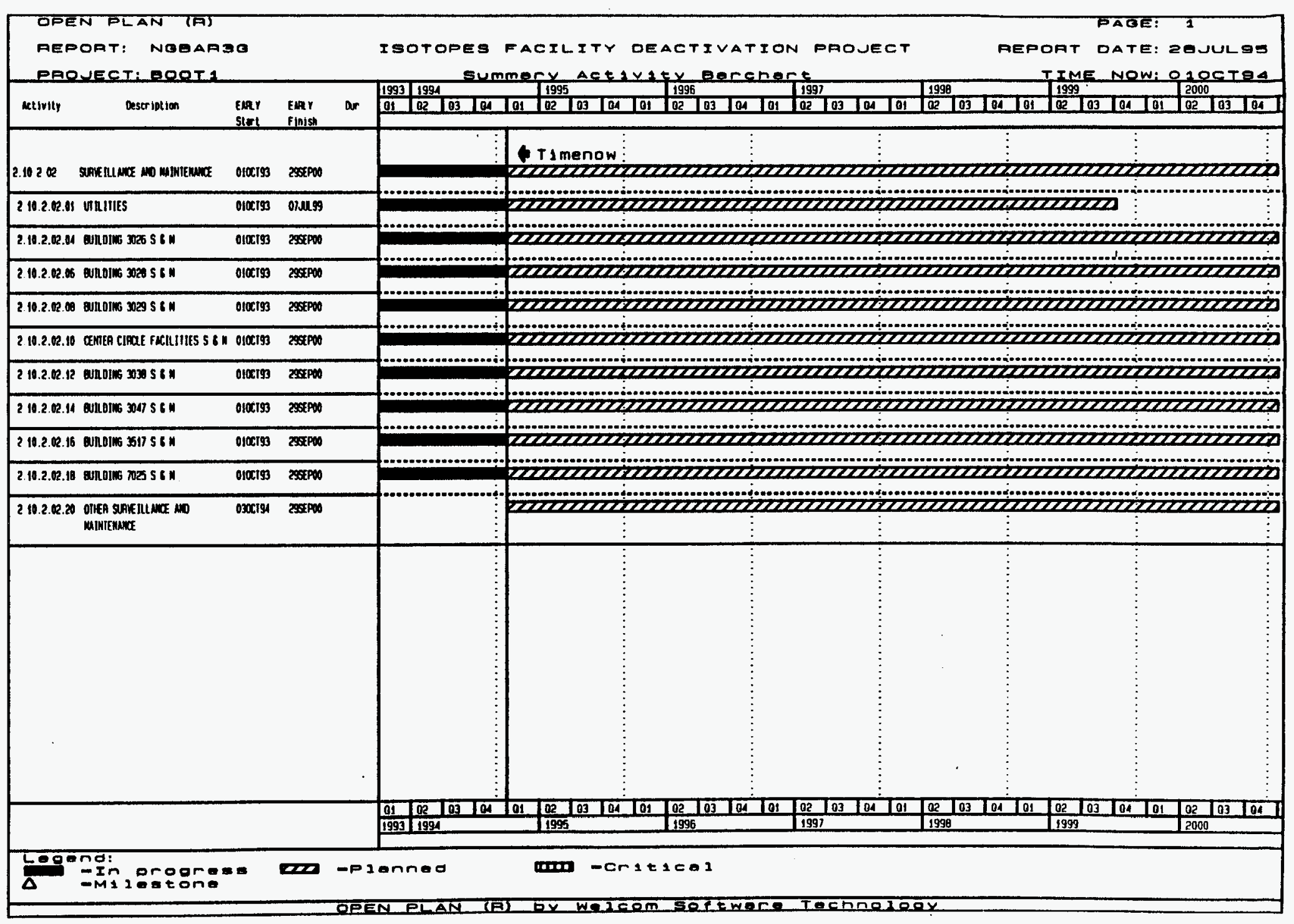

Fig. 3.2. Gantt charts and milestone schedules (continued). 
3-31

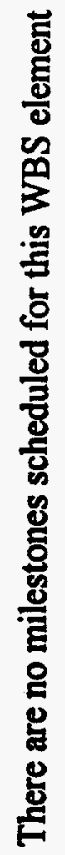

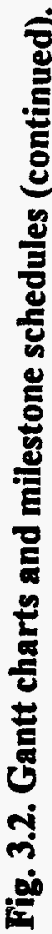




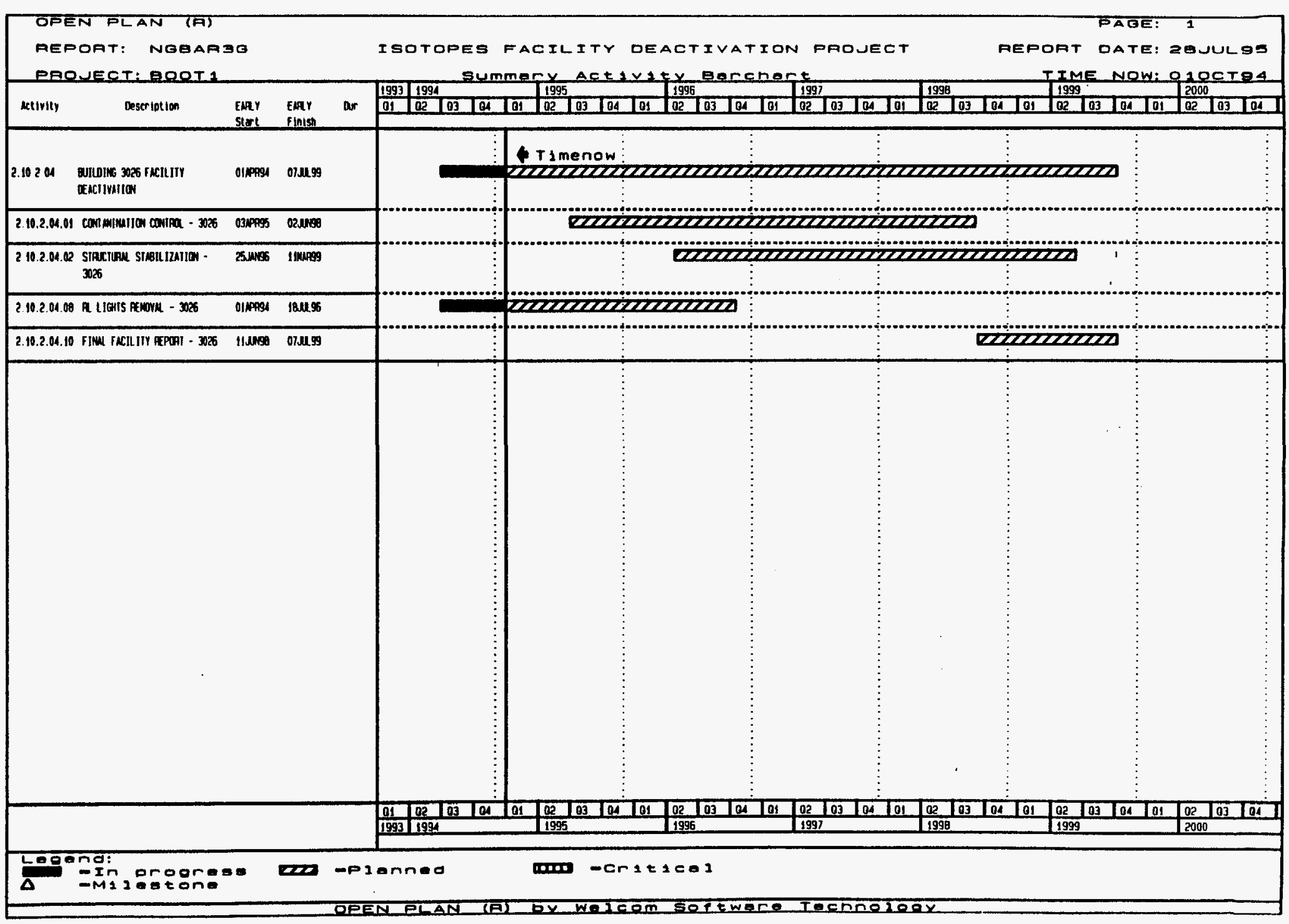

Fig. 3.2. Gantt charts and milestone schedules (continued). 


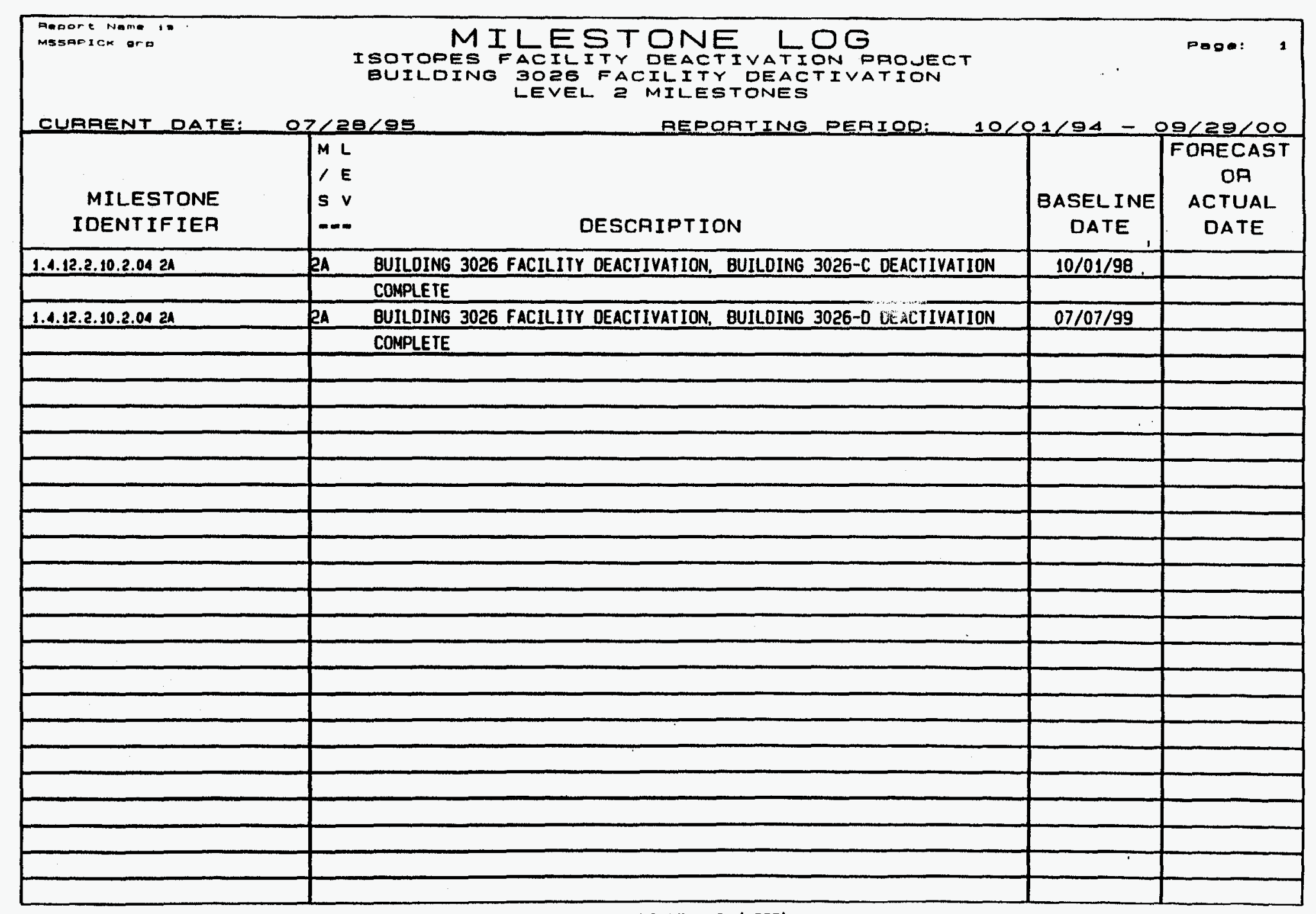

MONTHLY SCHEDULE STATUS REPORT (MSSA) LOG

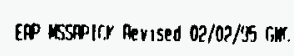

Fig. 3.2. Gantt charts and milestone schedules (continued). 


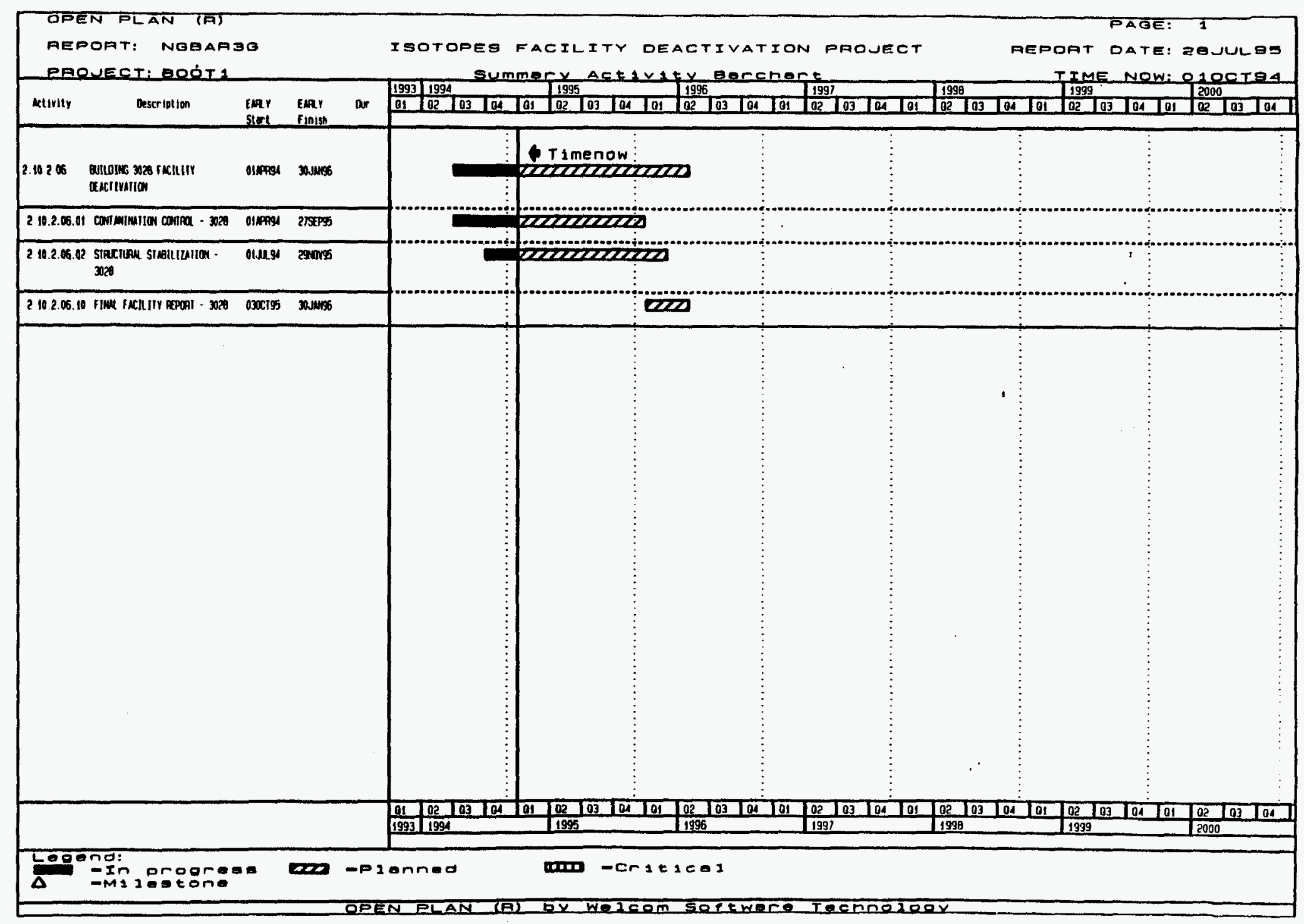

Fig. 3.2. Gantt charts and milestone schedules (continued). 


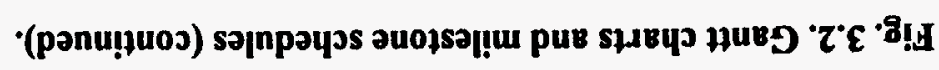

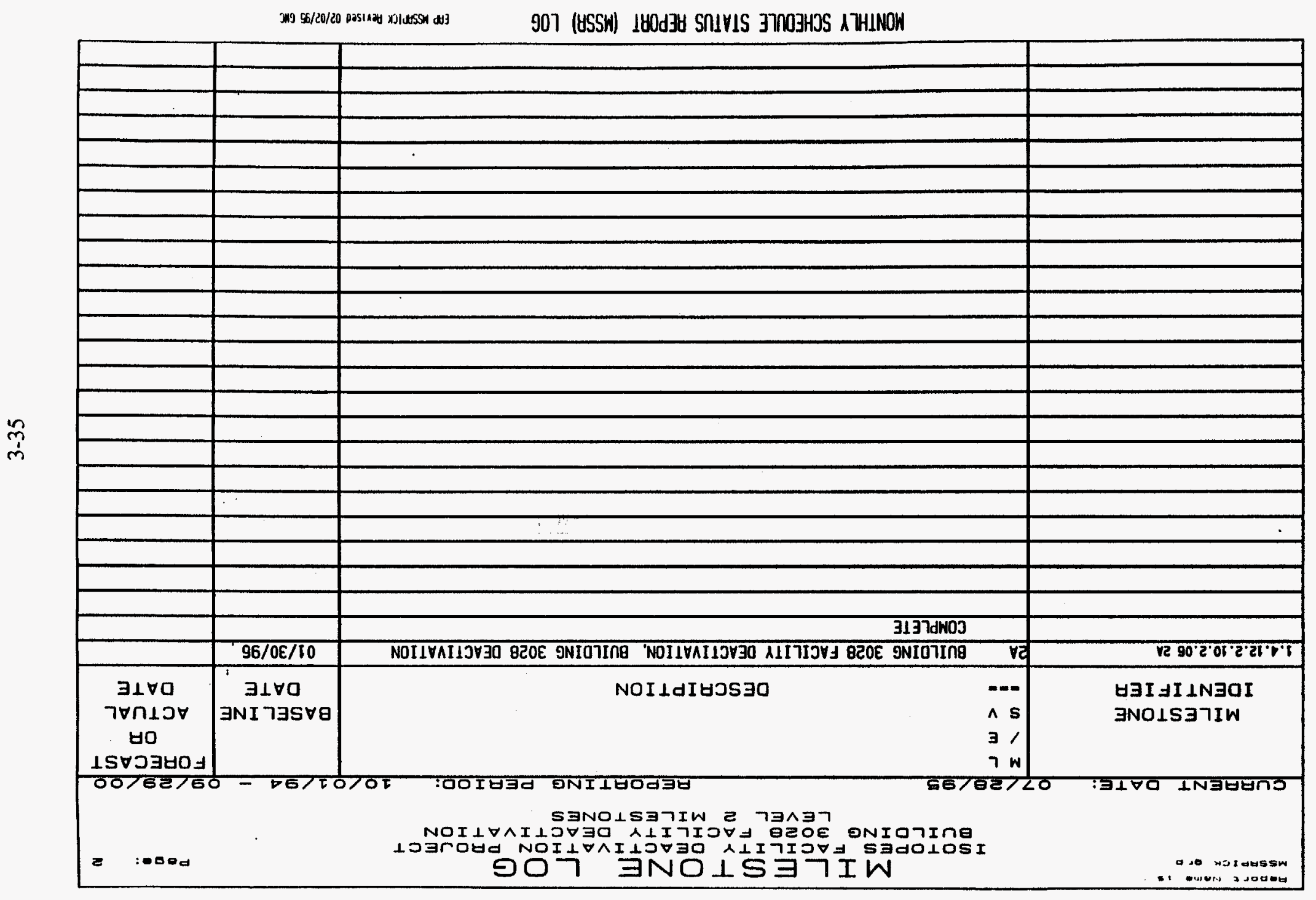




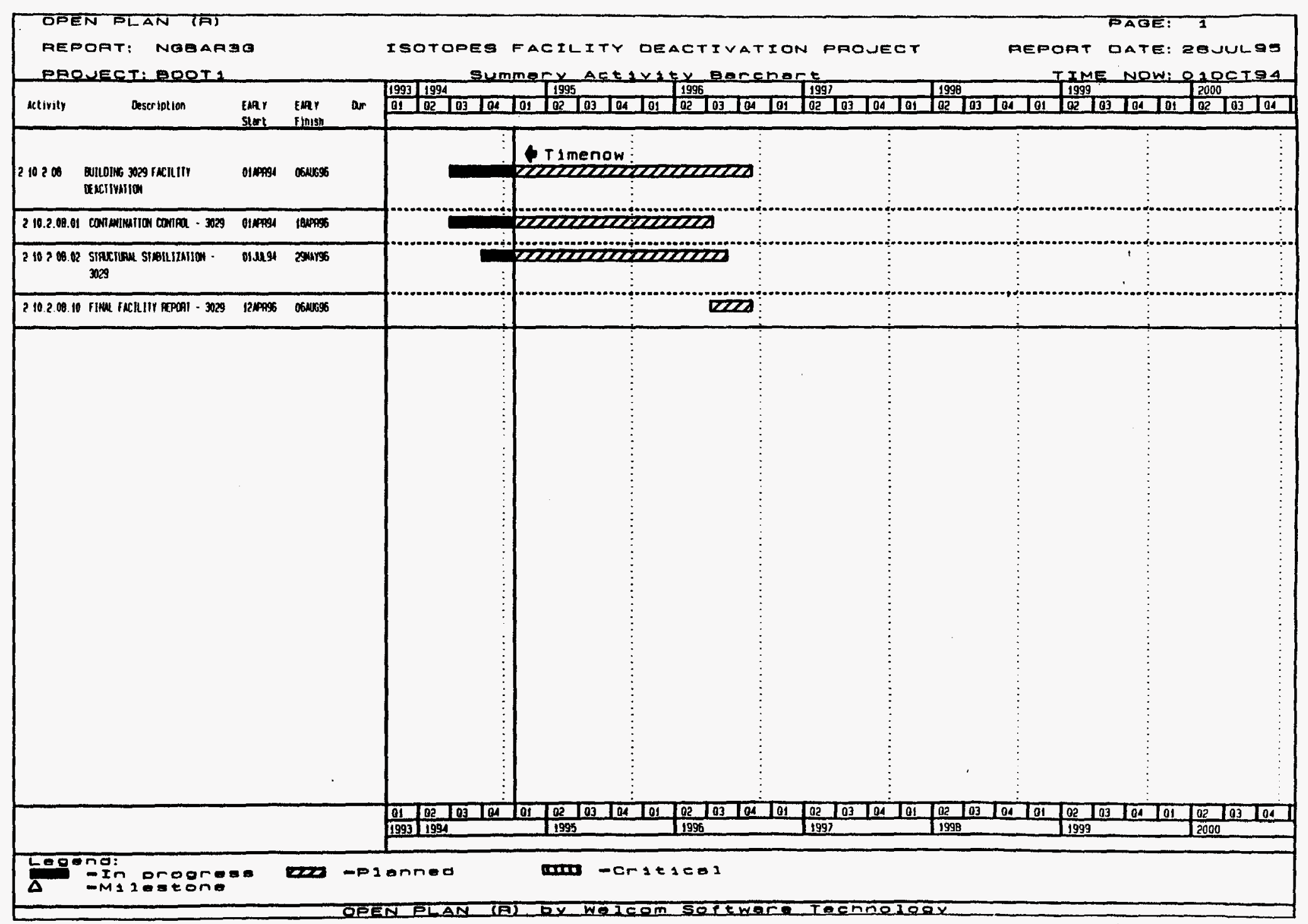

Fig. 3.2. Gantt charts and milestone schedules (continued). 


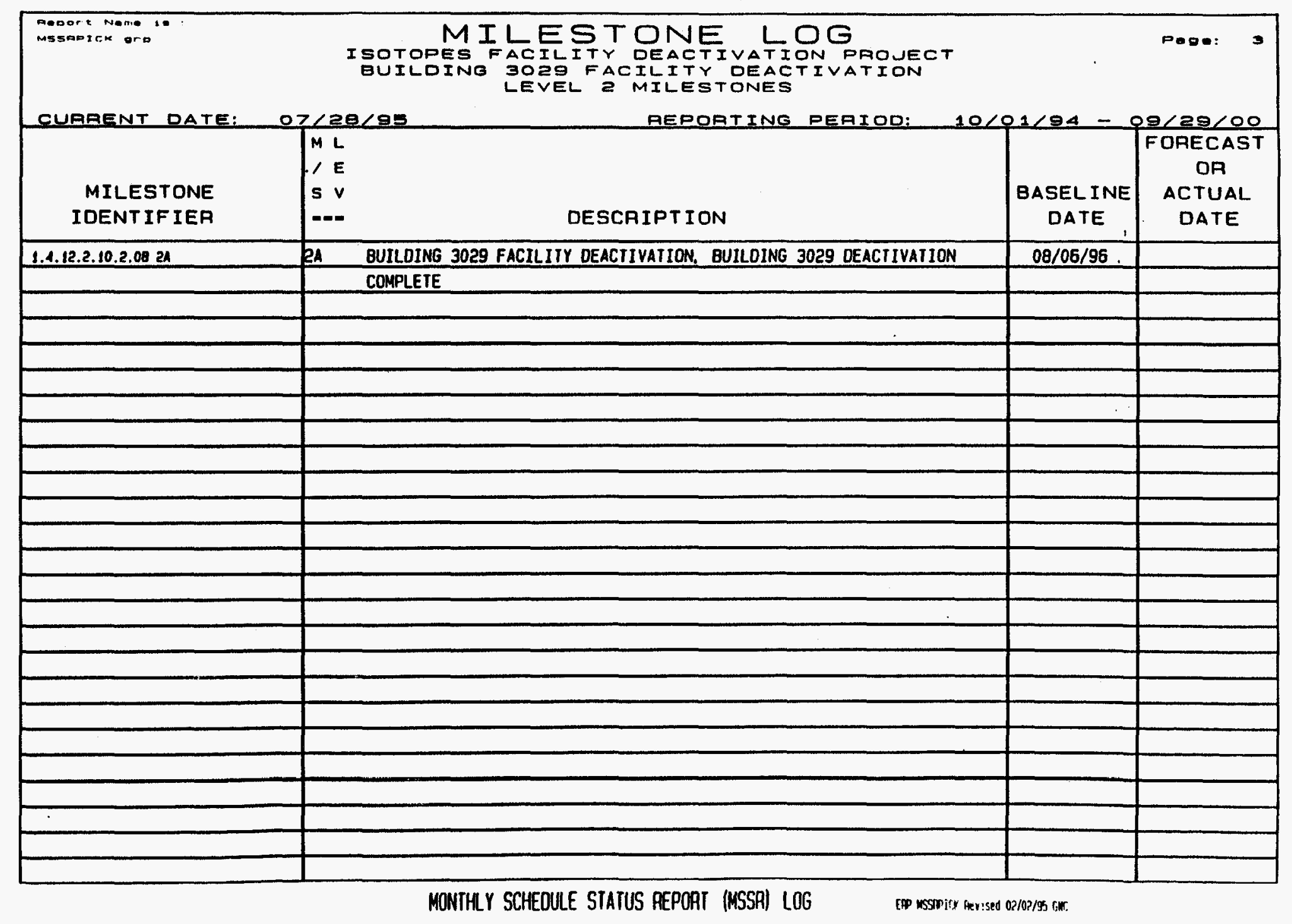

Fig. 3.2. Gantt charts and milestone schedules (continued). 


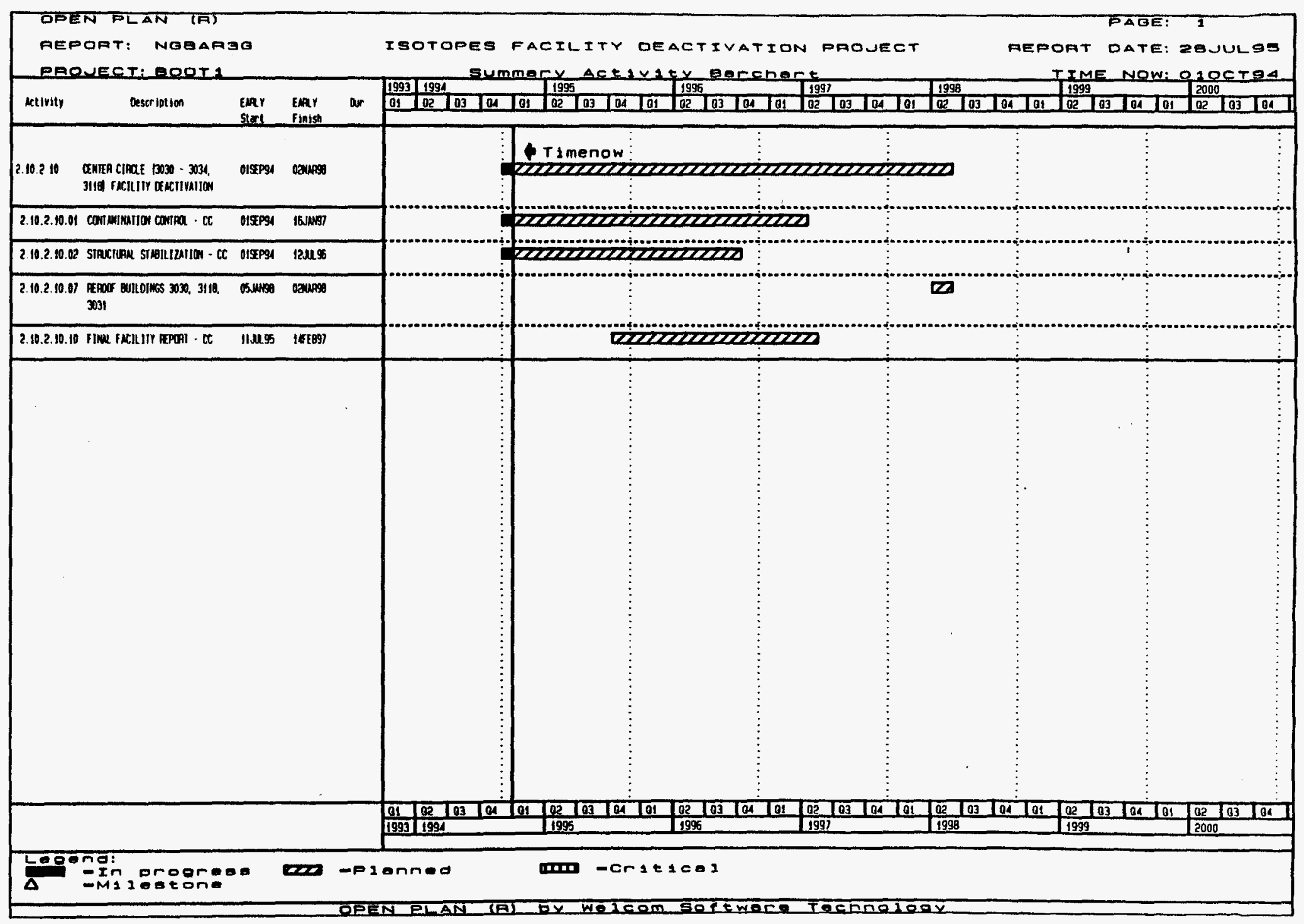

Fig. 3.2. Gantt charts and milestone schedules (continued). 


\begin{tabular}{|c|c|c|c|}
\hline \multirow[t]{2}{*}{ 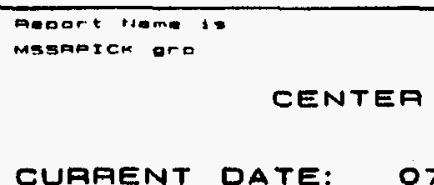 } & \multirow{2}{*}{\multicolumn{2}{|c|}{ 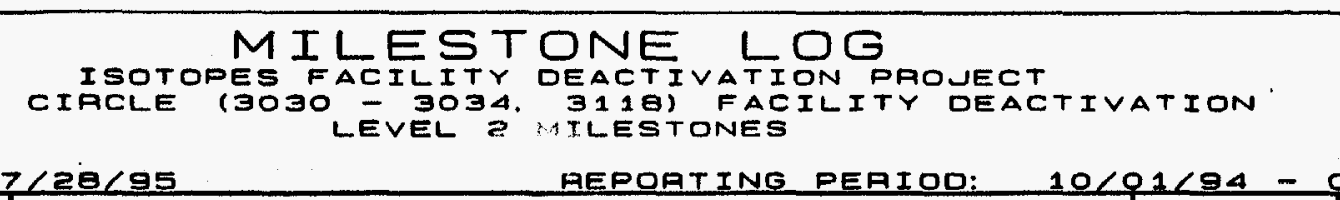 }} & \multirow{3}{*}{$\begin{array}{c}\text { poon: } \\
\text { O9/29/OO } \\
\text { FORECAST } \\
\text { OA } \\
\text { ACTUAL } \\
\text { DATE }\end{array}$} \\
\hline & & & \\
\hline $\begin{array}{l}\text { MILESTONE } \\
\text { IDENTIF IEA }\end{array}$ & $\begin{array}{lll}M & L \\
/ & E \\
S & V \\
-- & \end{array}$ & $\begin{array}{c}\text { BASEL INE } \\
\text { DATE }\end{array}$ & \\
\hline \multirow[t]{2}{*}{ 1.4.12.2.10.2.10 21 } & CENTEA CIACLE (3030 - 3034, 3118) FACILITY DEACTIVATION, BUILOING & $09 / 29 / 95$ & \\
\hline & 3033-A DEACTIVATION COMPLETE & & \\
\hline \multirow[t]{2}{*}{ 1.1.12.2.10.2.10 2A } & CENTEA CIRCLE $(3030-3034,3118)$ FACILITY DEACTIVATION. BUILOING & $11 / 14 / 95$ & \\
\hline & 3031 DEACTIVATION COMPLETE & & \\
\hline \multirow[t]{2}{*}{ 1.4.12.2.10.2.10 2A } & CENTEA CIRCLE $(3030-3034,3118)$ FACILITY DEACTIVATION, BUILDING & 03/04/96 & \\
\hline & 3034 DEACTIVATION COMPLETE & & \\
\hline \multirow[t]{2}{*}{ 1.4.12.2.10.2.10 2A } & CENTER CIACLE (3030 - 3034, 3118) FACILITY DEACTIVATION, BUILDING & $03 / 19 / 96$ & \\
\hline & 3118 DEACTIVATION COMPLETE & & \\
\hline \multirow[t]{2}{*}{ 1.4.12.2.10.2.10 21} & CENTER CIACLE (3030 - 3034, 3118) FACILITY DEACTIVATION, BUILDING & $06 / 24 / 96$ & \\
\hline & 3033 DEACTIVATION COMPLETE & & \\
\hline \multirow[t]{2}{*}{ 1.4.12.2.10.2.1021 } & CENTER CIRCLE (3030 - 3034, 3118) FACILITY OEACIIVATION, BUILOING & $07 / 17 / 96$ & \\
\hline & 3030 DEACTIVAIION COMPLETE & & \\
\hline \multirow[t]{2}{*}{ 1.4.12.2.10.2.10 2A } & 2A CENTER CIACLE $(3030-3034,3118)$ FACILITY DEACTIVATION, BUILDING & $02 / 14 / 97$ & \\
\hline & 3032 DEACTIVATION COMPLETE & & \\
\hline & & & \\
\hline & & & \\
\hline & & & \\
\hline & & & \\
\hline & & & \\
\hline & & & \\
\hline & & & \\
\hline & & & \\
\hline & & & \\
\hline & & & \\
\hline
\end{tabular}

MONTHLY SCHEOULE STATUS REPOPT (MSSP) LOG

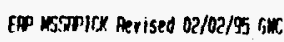

Fig. 3.2. Gantt charts and milestone schedules (continued). 


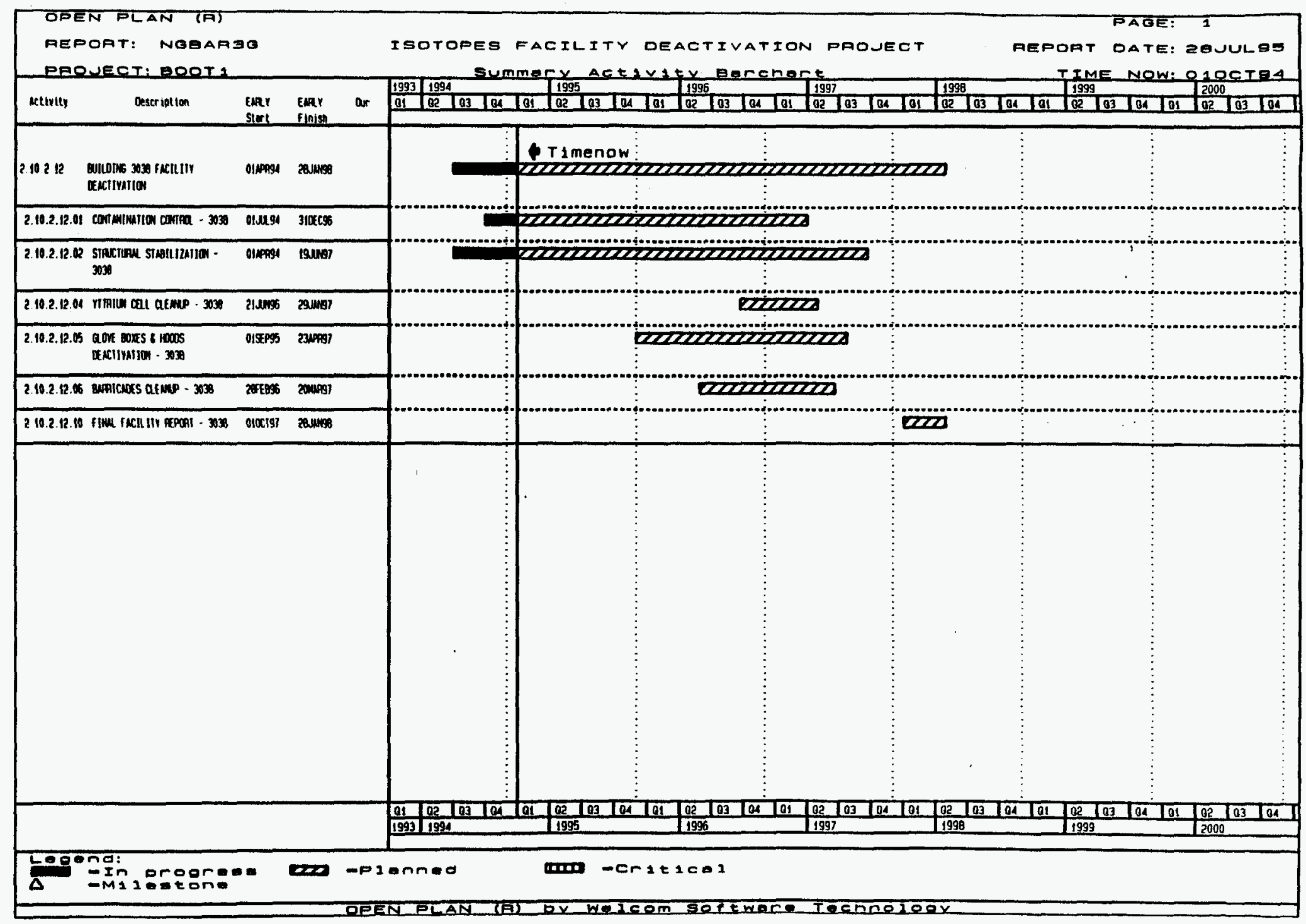

Fig. 3.2. Gantt charts and milestone schedules (continued). 


\begin{tabular}{|c|c|c|c|}
\hline 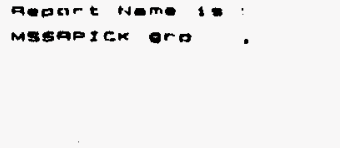 & 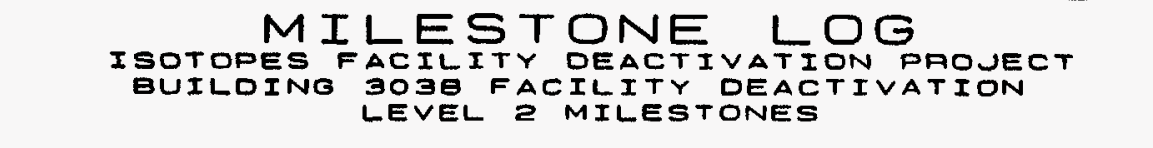 & (n) & Poop: 5 \\
\hline CURAENT DATE: & REPOATING PERIOD: & $21 / 94=$ & $09 / 20 / 00$ \\
\hline $\begin{array}{l}\text { MILESTONE } \\
\text { IDENT IF IER }\end{array}$ & $\begin{array}{lll}M & L \\
, & E \\
S & V \\
--- & \text { DESCRIPTION }\end{array}$ & $\begin{array}{c}\text { BASEL INE } \\
\text { DATE }\end{array}$ & $\begin{array}{l}\text { FORECAST } \\
\text { OR } \\
\text { ACTUAL } \\
\text { DATE }\end{array}$ \\
\hline 1.4.12.2.10.2.12 $2 A$ & EA BUILDING 3038 FACILITY OEACIIVATION, BUILOING $3038-M$ OEACTIVATION & $01 / 08 / 97$ & \\
\hline & COMPLETE & & \\
\hline 1.4 .12 .2 .10 .2 .1224 & 2A BUILOING 3038 FACILIIY DEACTIVATION. BUILDING 3038-E DEACTIVATION - & $02 / 19 / 97$ & \\
\hline & COMPLEIE & & \\
\hline 1.4.12.2.10.2.12 21 & 2A BUILDING 3038 FACILITY DEACTIVATION, BUILDING 3038-AHF & $04 / 23 / 97$ & \\
\hline & IFCTIVATION COMPLETE & & \\
\hline & & & \\
\hline & & & \\
\hline & & & \\
\hline & & & \\
\hline & & & \\
\hline & & & \\
\hline & & & \\
\hline & & & \\
\hline & & & \\
\hline & & & \\
\hline & & & \\
\hline & & & \\
\hline & & & \\
\hline & & & \\
\hline & & & \\
\hline & & & \\
\hline & & & \\
\hline & & & \\
\hline
\end{tabular}

Fig. 3.2. Gantt charts and milestone schedules (continued). 


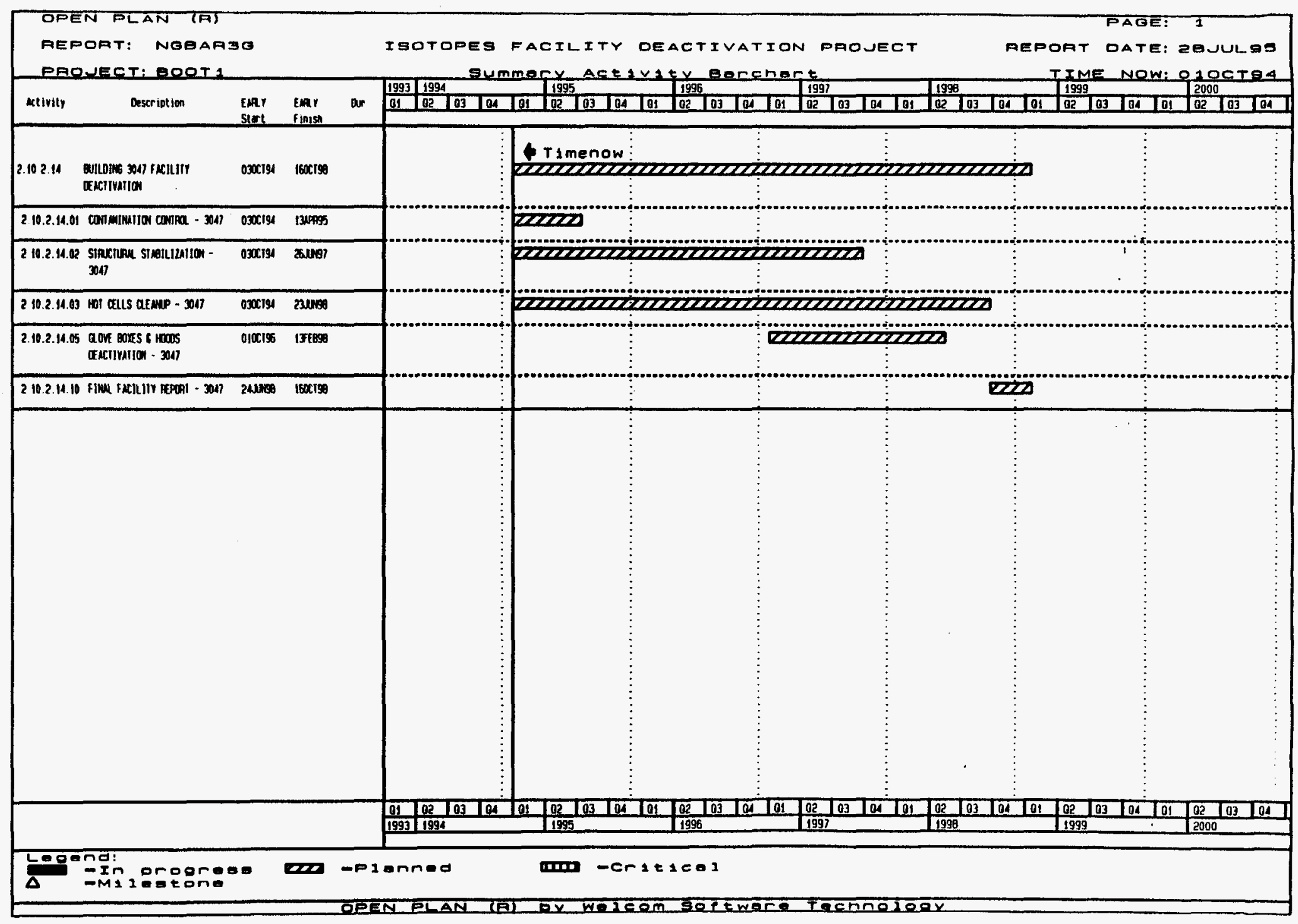

Fig. 3.2. Gantt charts and milestone schedules (continued). 


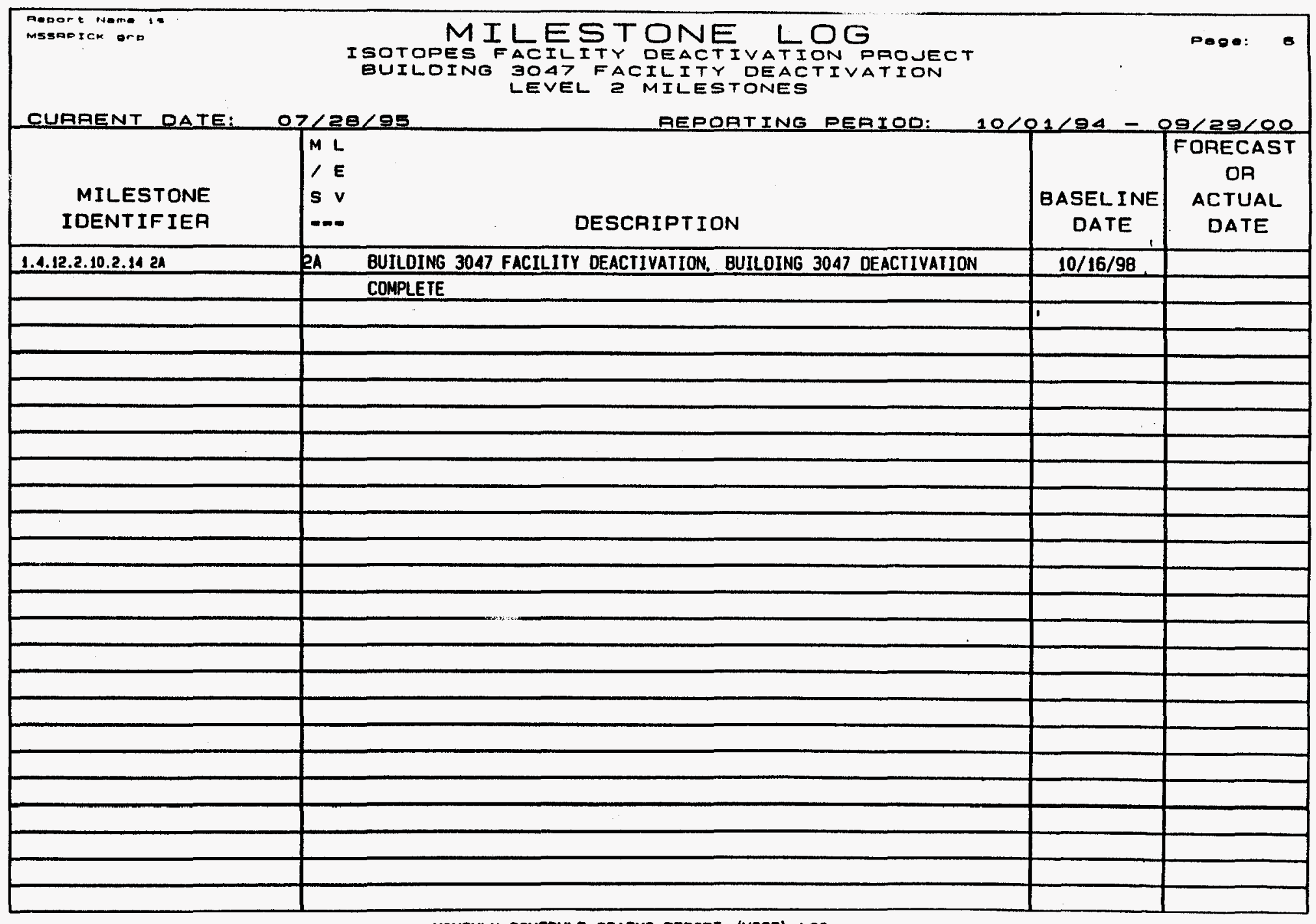

MONTHLY SCHEOULE STATUS REPORT (MSSA) LOG

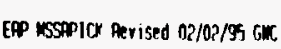

Fig. 3.2. Gantt charts and milestone schedules (continued). 


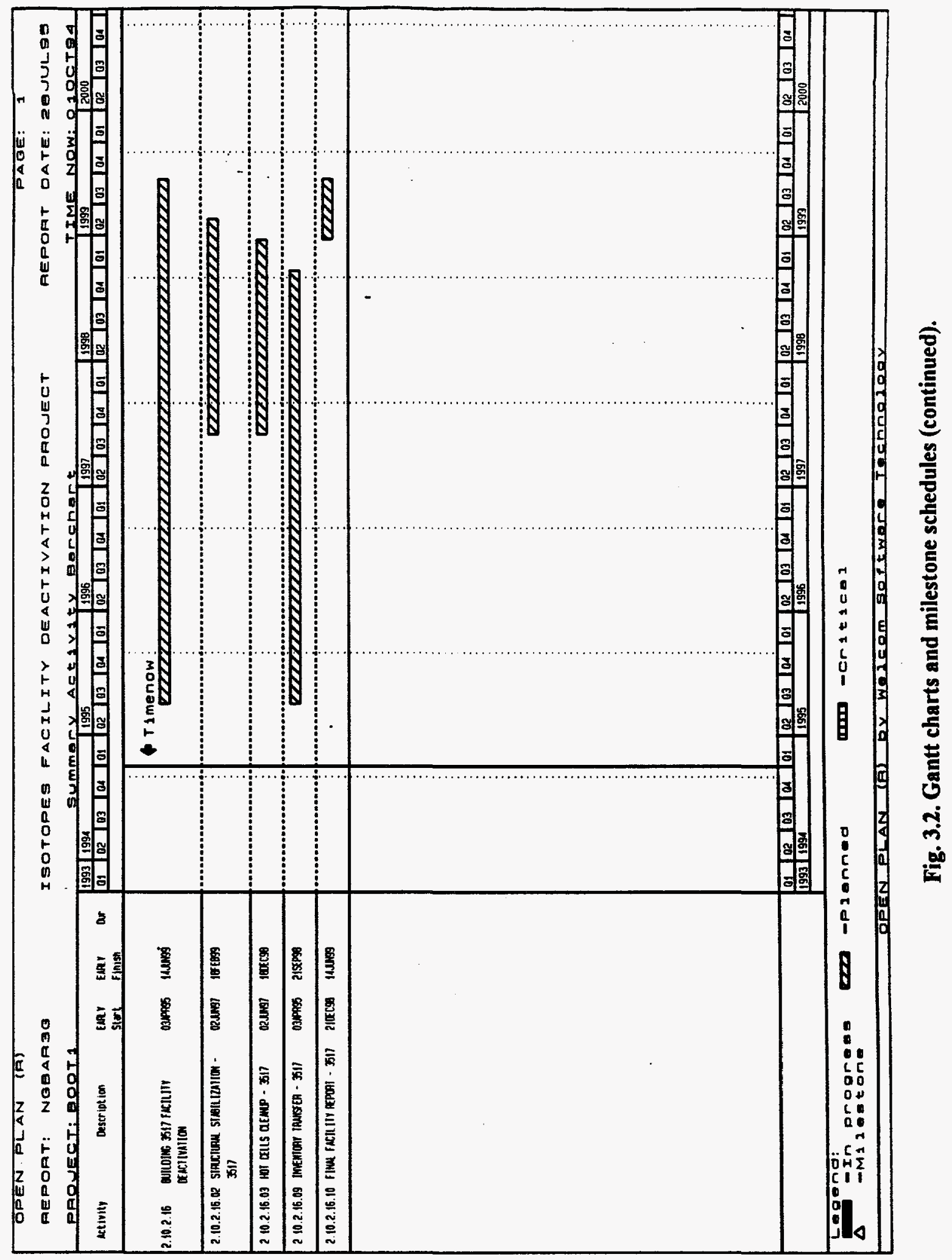




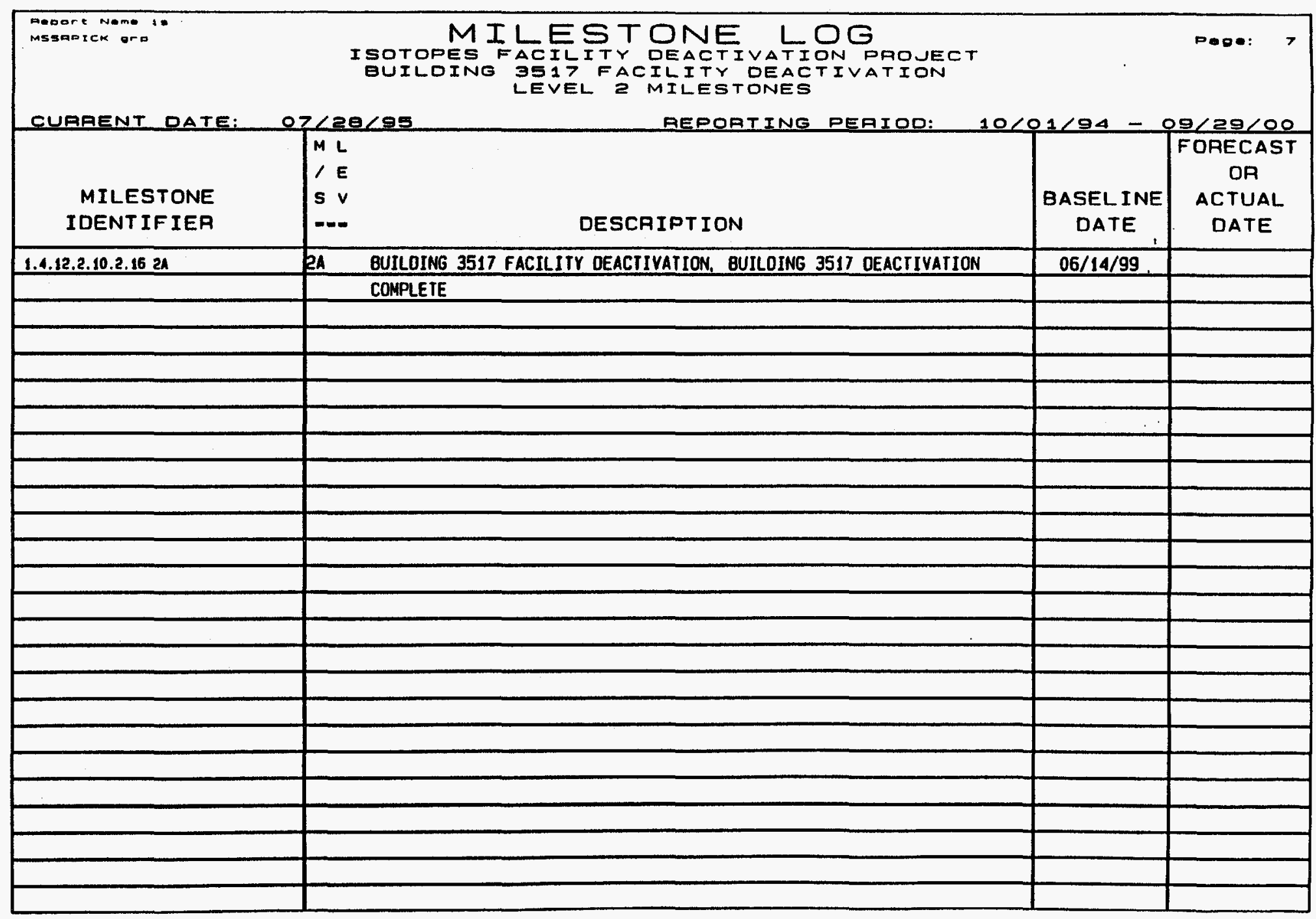

MONTHLY SCHEOULE STATUS AEPORT (MSSA) LOG

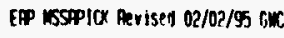

Fig. 3.2. Gantt charts and milestone schedules (continued). 


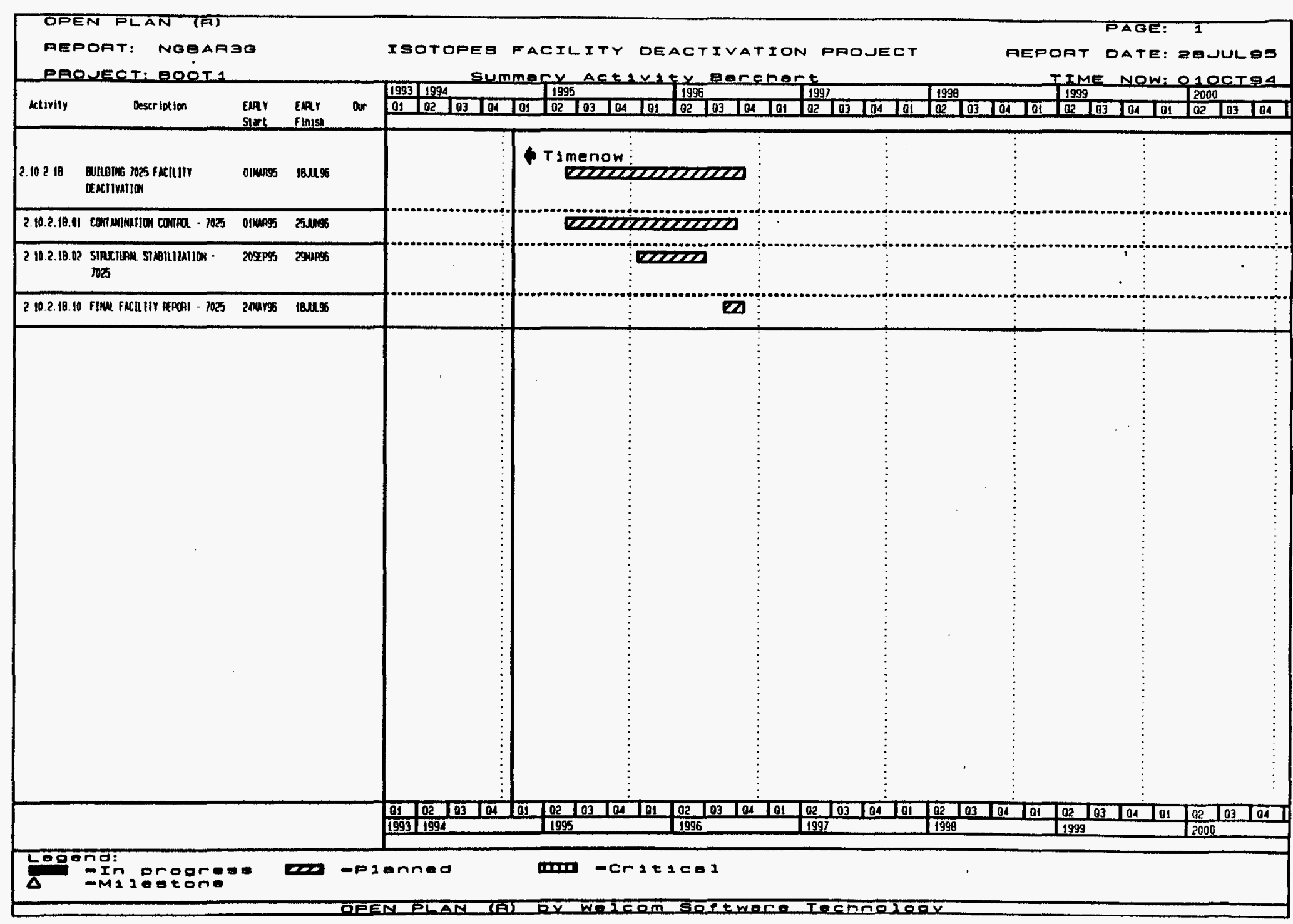

Fig. 3.2. Gantt charts and milestone schedules (continued). 


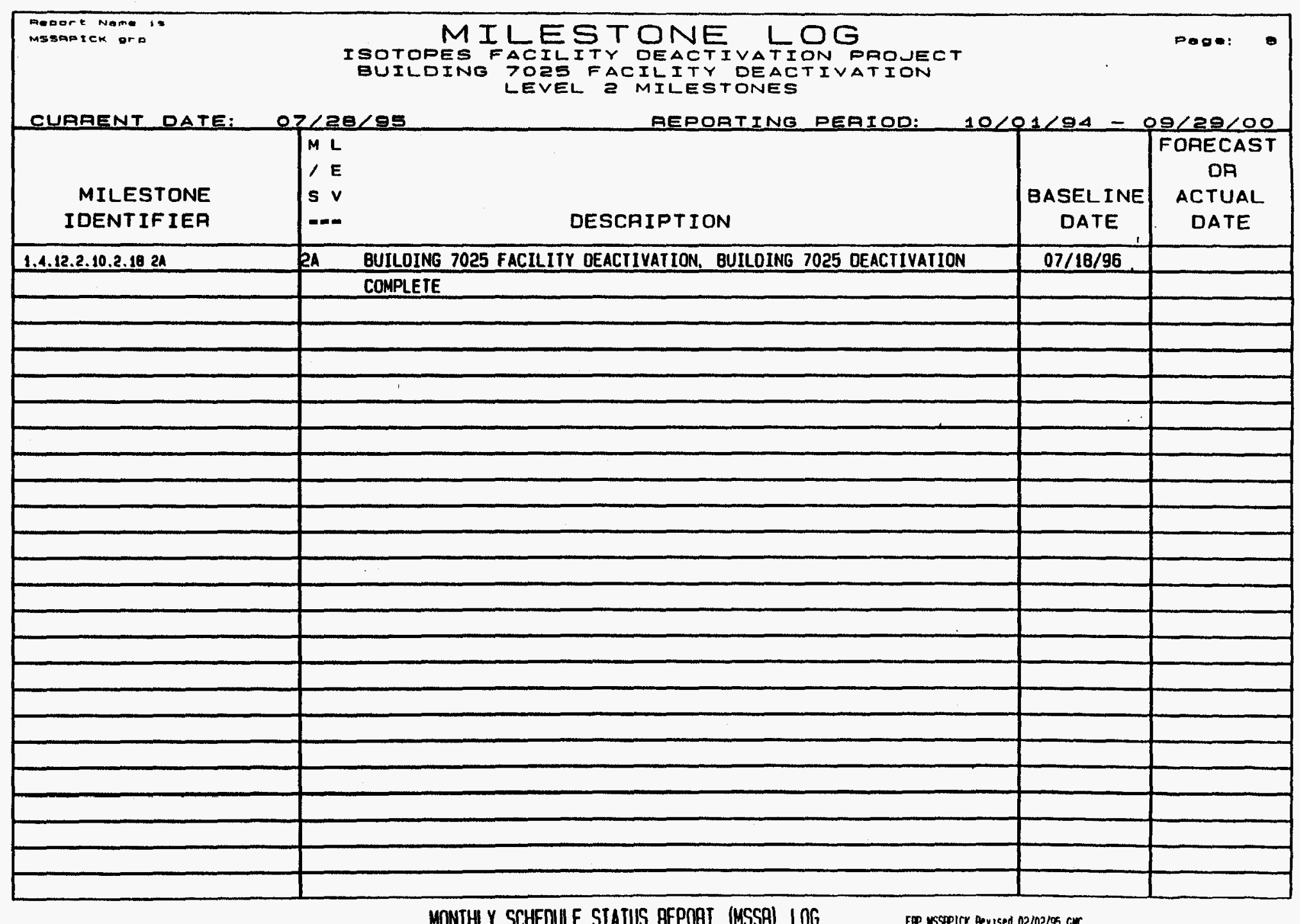

Fig. 3.2. Gantt charts and milestone schedules (continued). 


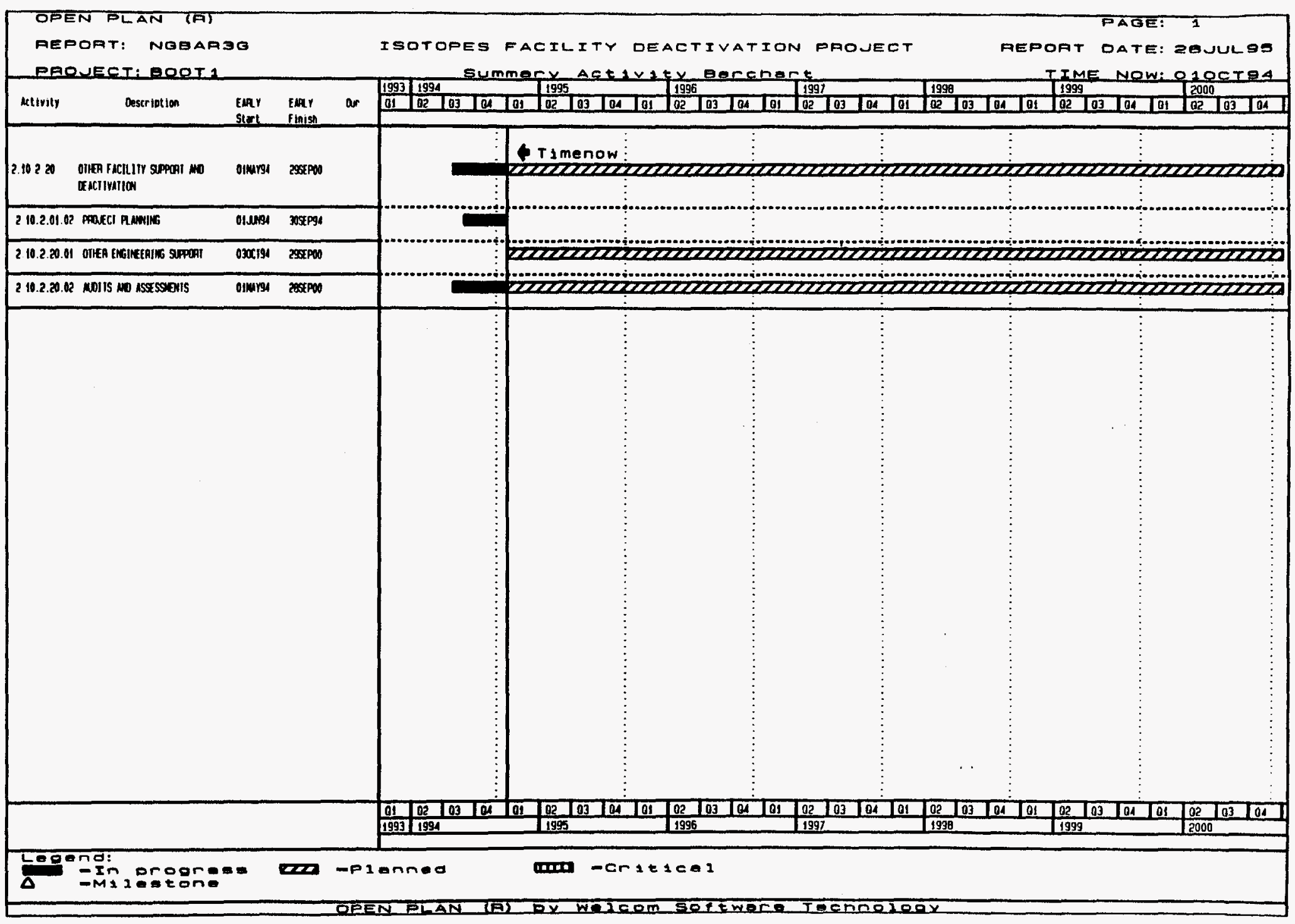

Fig. 3.2. Gantt charts and milestone schedules (continued). 


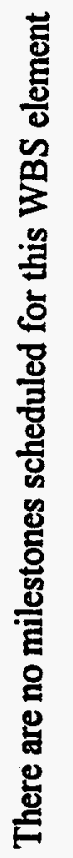




\subsection{ADS OR-6504IS BASIS OF ESTIMATE}

- D\&D activities will not be performed for at least 10 years beyond the completion of deactivation activities.

- Technical staff is knowledgeable of procedures required to manage specific work task.

- All of the deactivation activities are covered by existing ORNL National Environmental Policy Act (NEPA) documentation. Any additional NEPA documentation will be completed in parallel with other project activities with additional resources.

- Waste tanks WC-10 and WC-2 will be available to support deactivation activities through FY 1997.

- Trained and qualified personnel are available to perform deactivation activities.

- ORRs will be conducted by the project staff or by an appointed review committee. No other ORRs will be required.

- Technical planning bases for the project will be implemented as described. Appropriate project contingency will be provided and identified.

- Work inefficiencies are expected for radiation work involving respirators or supplied air.

- The only activity that has been identified as potentially requiring an ORR is the resumption of repackaging operations in Building 3517.

- Budget will be provided as planned in the funding profile.

- The cost estimate was compiled by Energy Systems Engineering from the estimates prepared by the ORNL organizations performing the work. The estimating methodologies and practices conform to the Energy Systems Project Estimating and Scheduling Standard Operating Manual, the DOE-ORO Estimating and Cost Control Manual for Construction Projects, and the Cost Estimating Hand Book for Environmental Restoration Projects. The estimate is an activity-based cost estimate.

- The resource data used to prepare the cost estimate are derived from current cost data and staffing requirements for existing work elements that continue for the duration of the project and from technical work descriptions and schedules prepared for each deactivation activity. These activities are described with cost data in the Isotopes Facilities Shutdown Program.

- The resources were priced using the ERDEC94C Standard Value File. The indirect costs, including steam and water use assessments, organization overheads, material procurement, and general and administrative burdens, were developed similarly.

- Utility costs for water, steam, air, electricity, etc. are moved to and collected in the surveillance and maintenance cost when the deactivation process is concluded.

- Work is performed in a 40-hour work week. Overtime can be used as needed. 
- Utility and S\&M cost is extended for five years after deactivation of the facility. Costs are compiled using a spreadsheet of cost from Energy Systems and verbal instruction from Cal Pepper.

- Contingency is set at up to $30 \%$ in the outyears and lower (5\%) in the early years because of better project definition

- All waste generated will be turned over to Waste Management for disposal. 


\subsection{ADS OR-6504IS FISCAL YEAR COST LIFECYCLE PLAN}

The following section presents the fiscal year cost profile by WBS element. The report provides the total budget outlay for the life cycle. 


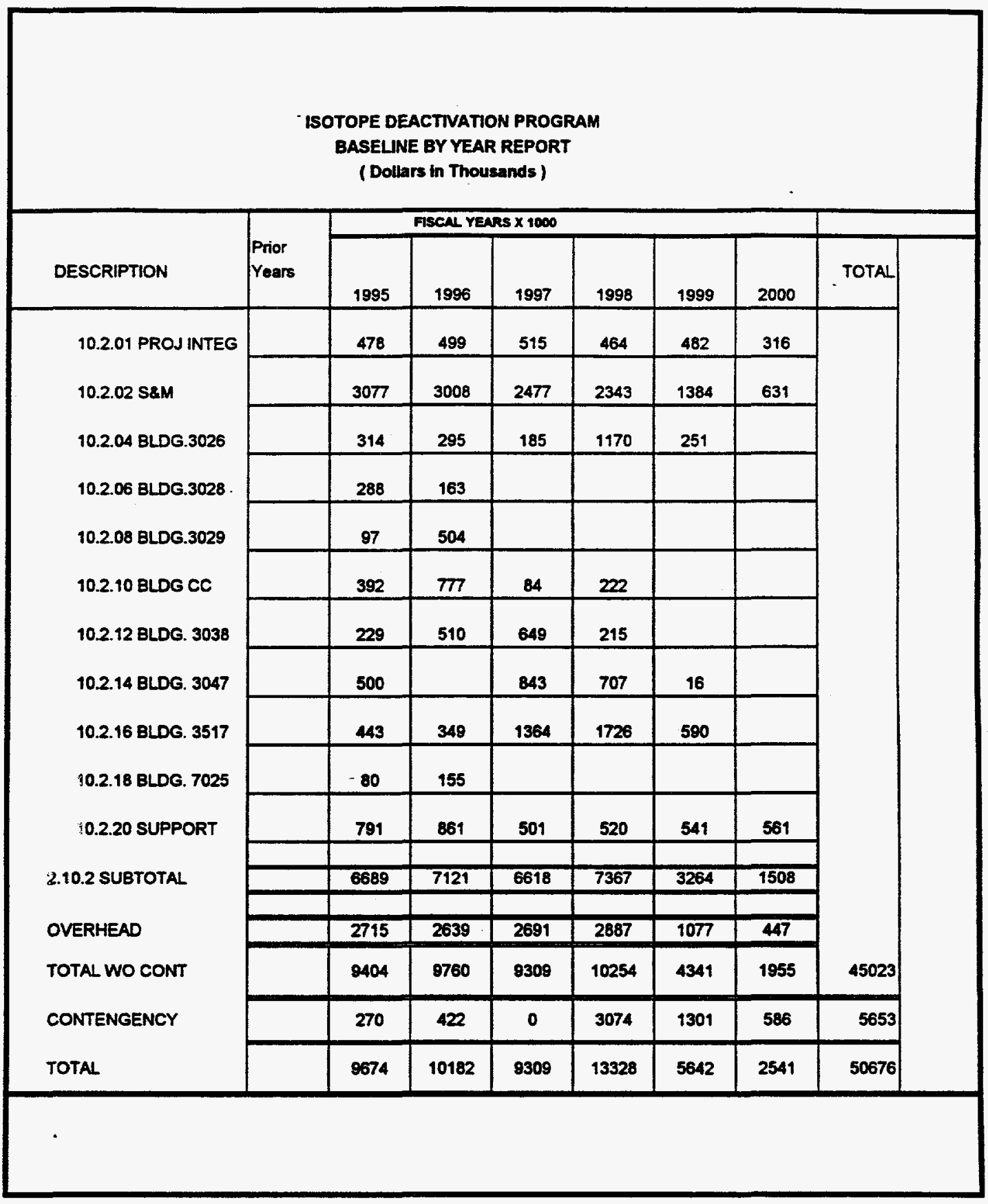




\subsection{ADS OR-6504IS PROJECT/PARTICIPANT SUMMARY}

The following pages contain the participant summaries for ADS OR-6504IS. 
ISOTOPE DEACTIVATION PROGRAM

FISCAL YEAR SUMARAY

$\$ 1=\$ 1000$

$07 / 28 / 1995$

Arranged By: Wes / Participant Code Fiscal Year Range 1995 - 2000

2.10.2.09 PROJECT INTEGRATIOW CO69 CENTRAL ENGIMEERING COB7 ENVIROMMENTAL RESTORATION

TOtal PROJECT INTEGRATION

2.10.2.02 SURVEILLANCE AND MAINTENANCE X003 CHEMICAL TECHHOLOGY X021 PLANT \& EOUIPMENT X026 OFC OF OUAL PROGS \& INSP $X 034$ INST \& CONTROLS X036 OFC OF SAF \& MEALTH PROT

Total SURVEILlanCE and maInTENANCE

2.10.2.04 BUILDING 3026 FACILITY DEACTIV CO69 CENTRAL ENGIMEERJMG CO87 ENVIROMMENTAL RESTORATION MKS1 MK-F OAK RIDGE FPSC TSOT TECH SUPPORT CONTRACTOR X003 CHEMICAL TECHMOLOCY X021 PLANT \& EQUIPHENT X036 OFC OF SAF \& MEALTH PROT

TOtal BUILDIMG 3026 FAEILITY DEACTIV

2.10.2.06 BUILDING 3028 FACILITY DEACTIV CO69 CENTRAL EMGINEERING COB7 ENVIROMMENTAL RESTORATION MK63 MK-F DH, OAK RIDGE TSOI TECH SUPPORT CONTRACTOR X003 CHEMICAL TECHNOLOGY X021 PLANT \& EOUIPMENT X036 OFC OF SAF HEALTH PROT

Total BUILING 3028 FACILITY DEACTIV

2.10.2.08 BUILDIMG 3029 FACILITY DEACTIV COS9 CENTRAL ENGINEERIMG C087 ENVIRONEENTAL RESTORATION MK51 MX - F OAK RIDGE FPSC MK63 UK-F DH, OAK RIDGE

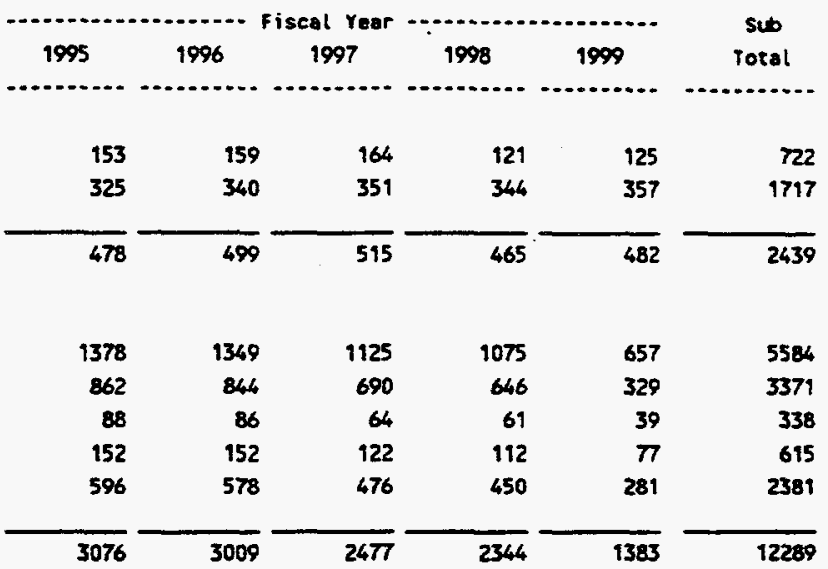

\begin{tabular}{rrrrrr}
$\cdot$ & $\cdot$ &. & 5 & 6 & 11 \\
$\dot{*}$ & $\dot{*}$ &. & 4 & 4 & 8 \\
278 & 224 & 46 & 378 & 112 & 1038 \\
6 & 29 & 85 & 248 & 37 & 405 \\
30 & 43 & 54 & 328 & 44 & 499 \\
\hline 314 & 296 & 185 & 1170 & 252 &
\end{tabular}

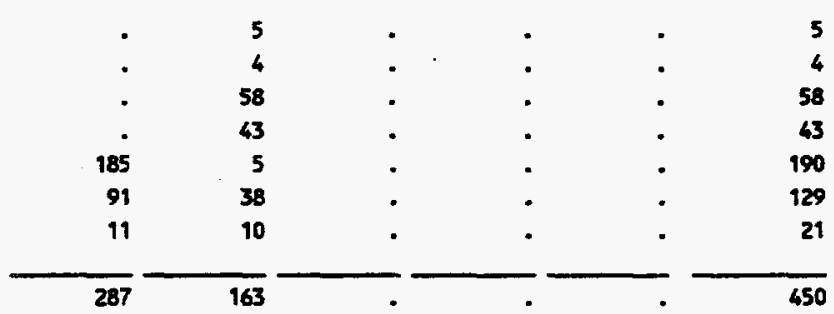

11

8 39 
ISOTOPE DEACTIVATION PROGRAM

FISCAL YEAR SUMARY

$s 1=\$ 1000$

$07 / 28 / 1995$

Arranged By: WBS / Participant Code Fiscal Year Range 1995 - 2000

TSO1 TECH SUPPORT CONTRACTOR X003 CHEMICAL TECHNOLOGY X021 PLANT \& EQUIPNENT X036 OFC OF SAF \& HEALTH PROT

Total BUILDING 3029 FACILITY DEACTIV

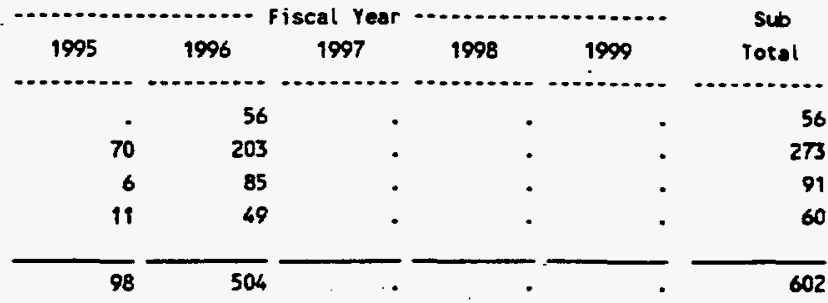

2.10.2.10 CENTER CIRCLE 3030/3034.3118 F C069 CENTRAL EMGINEERING CO87 ENVIROAMENTAL RESTORATION TSO1 TECH SUPPORT CONTRACTOR X0O3 CHEMICAL TECHNOLOGY X021 PLANT \& EOUIPHENT X036 OFC OF SAF 2 HEALTH PROT

Total CENTER CIRCLE 3030/3034.3118 F

2.10.2.12 BUILOING 3028 C069 CENTRAL ENGIMEERING CO87 ENVIRONMENTAL RESTORATION MK63 MK-F DH, OAK RIDGE TSO1 TECH SUPPORT CONTRACTOR XOOZ CHEMICAL TECHMOLOSY X021 PLANT \& EOUIPHENT X036 OFC DF SAF \& HEALTH PROT

Total BUILOING 3028

2.10.2.14 BUILDING 3047 FACILITY DEACTIV COS9 CENTRAL EMGIMEERIMG CO87 ENVIRONAETAL RESTORATIOH MK63 MK-F DH, OAK RIDGE TSOI TECH SUPPORT CONTRACTOR X003 CHEMICAL TECHNOLOGY X021 PLANT \& EONIPMENT X036 OFC OF SAF \& HEALTH PROT

Total BUILIMG 3047 FACILITY DEACTIV

\begin{tabular}{rrrrrr}
5 & 42 & 5 & $\cdot$ & $\cdot$ & 52 \\
4 & 24 & 4 & $\cdot$ & $\cdot$ & 32 \\
22 & 100 & 23 &. &. & 145 \\
183 & 345 & 26 & 31 &. & 585 \\
109 & 164 & 15 & 160 &. & 448 \\
70 & 102 & 10 & 31 &. & 213 \\
\hline 393 & $m$ & 83 & 222
\end{tabular}

2.10.2.16 BUILDIMG 3517 FACILITY DEACTIV AEO1 ARCMITECT-ENGIMEER COSO CENTRAL EMGIMEERIMG

\begin{tabular}{|c|c|c|c|c|c|}
\hline - & - & - & 12 & 2 & 16 \\
\hline • & - & • & 10 & 2 & 12 \\
\hline 31 & - & • & • & - & 31 \\
\hline • & - & • & 56 & 9 & 65 \\
\hline 279 & - & 555 & 422 & 2 & 1258 \\
\hline 147 & - & 243 & 175 & - & 565 \\
\hline 43 & - & 45 & 32 & 2 & 122 \\
\hline$\overline{500}$ & & 843 & 707 & $\overline{17}$ & $\overline{2067}$ \\
\hline
\end{tabular}


ISOTOPE DEACTIVATION PROGRAM

FISCAL YEAR SUMHARY

$\$ T=\$ 1000$

$07 / 28 / 1995$

Arranged By: LBS / Participant code

Fiscal Year Range 1995 - 2000

CO87 ENVIRONMENTAL RESTORATION

MK63 MK-F DH, OAK RIDGE

TSOT TECH SUPPORT CONTRACTOR

XDO3 CHEMICAL TECHNOLOCY

XO21 PLANT \& EQUIPHENT

X036 OFC OF SAF \& HEALTH PROT

Total BUILOING 3517 FACILITY DEACTIV

2.10.2.18 BUILDING 7025 FACILITY DEACTIV C069 CENTRAL ENGINEERIMG

COB7 ENVIRONAENTAL RESTORATION

TSO 1 TECH SUPPORT CONTRACTOR

X003 CHEMICAL TECHNOLOGY

X021 PLANT E EQUIPMENT

X036 OFC OF SAF 2 HEALTH PROT

TOtaL BUILOING 7025 FACILITY DEACTIV

2.10.2.20 OTHER FACILITY SUPPORT AMD DEA AEO1 ARCHITECT-ENGIMEER

CQ64 INES PROCUREMENT

COSO CEMTRAL ENGINEERIMG

CO87 ENVIRONMENTAL RESTORATION

SCO1 OFFSITE SUBCONTRACT

X003 CHENICAL TECHNOLOCY

XO08 MEALTH SCIENCES RESEARCH

TOEAL OTHER FACILITY SUPPORT NOD DEA

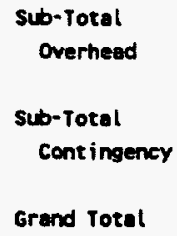

Grand Total

Sub

Total

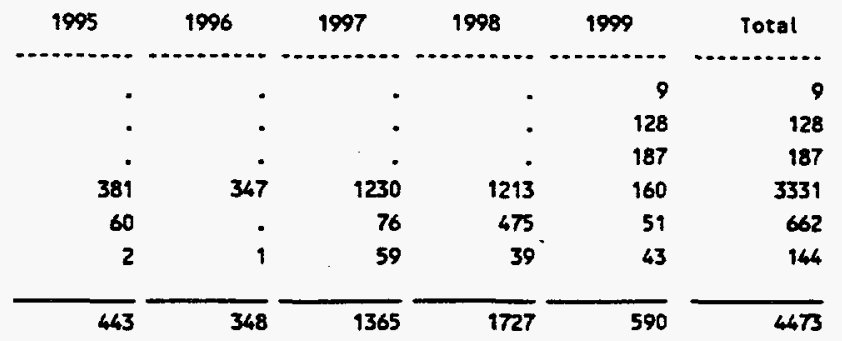

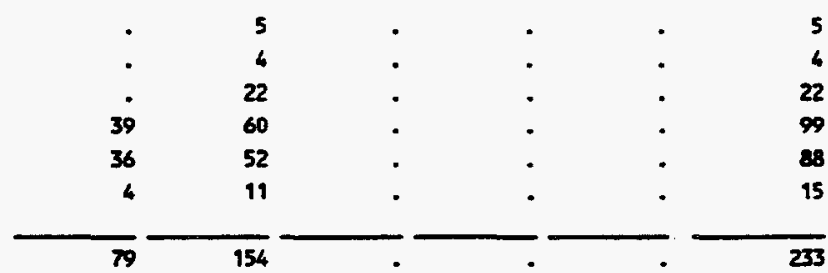

\begin{tabular}{rrrrrr}
40 & 42 & 43 & 45 & 47 & 217 \\
231 & 535 & 164 & 171 & 177 & 1270 \\
173 & 180 & 186 & 194 & 201 & 934 \\
11 &. &. &. &. & 11 \\
56 & 59 & 61 & 63 & 66 & 305 \\
43 & 44 & 46 & 48 & 50 & 231 \\
237 &. &. &. &. & 257 \\
\hline 791 & 860 & 500 & 521 & 541 & 3213
\end{tabular}

\begin{tabular}{|c|c|c|c|c|c|}
\hline 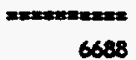 & 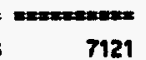 & 6619 & 7372 & 3265 & 31065 \\
\hline 2715 & 2639 & 2691 & 2887 & 1077 & 12009 \\
\hline$n=m=m=03=1$ & 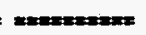 & 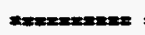 & zex: & 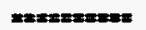 & 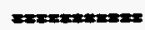 \\
\hline 9403 & 9760 & 9310 & 10259 & 4342 & 43074 \\
\hline 270 & 422 & 0 & 3074 & 1301 & 5067 \\
\hline 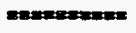 & 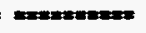 & $\operatorname{man}=1$ & & & $=$ \\
\hline 9673 & 10182 & 9310 & 13333 & 5643 & 48141 \\
\hline
\end{tabular}


ISOTOPE DEACTIVATION PROGRN

\author{
FISCAL YEAR SUMMARY \\ $s 1=\$ 1000$ \\ $07 / 28 / 1995$
}

Arranged By: WBS / Participant Code

Fiscal Year Range 1995 - 2000

2.10.2.01 PROJECT INTEGRATION

CO69 CENTRAL EXGINEERIMG

C087 ENVIRONMENTAL RESTORATION

Total PROJECT INTEgRATION

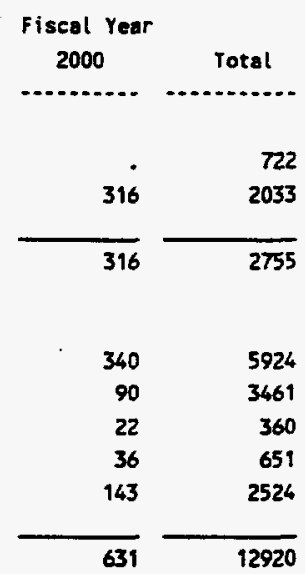

Total SURVEILLANCE AND MINTENANCE

2.10.2.04 BUILDING 3026 FACILITY DEACTIV C069 CENTRAL ENGINEERING C087 ENVIRONMENTAL RESTORATION MKS1 MK-F OAK RIDGE FPSC TSO1 TECH SUPPORT CONTRACTOR X003 CHEMICAL TECHMOLOGY XOZ1 PLANT \& EQUIPHENT X036 OFC OF SAF \& MEALTH PROT

Total BUILDING 3026 FACILITY DEACTIV

2.10.2.06 BUILDIMG 3028 FACILITY DEACTIV C069 CEMTRAL EMGINEERIMG COB7 EAVIRONMENTAL RESTCRATION MK63 MK-F DH, OAK RIDEE TSO1 TECH SUPPORT CONTRACTOR X003 Chenical technologr X021 PLANT \& EOUIPHENT X036 OFC OF SAF \& MEALTY PROT

TOtal BUILDING 3028 FACILITY DEACTIV

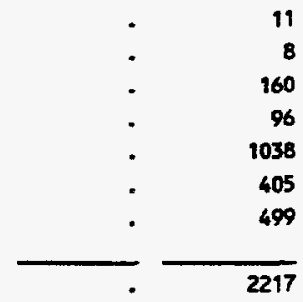

2.10.2.08 BUILOING 3029 FACILITY DEACTIV COS9 CEMTRAL ENGINEERING C087 ENVIRONHEUTAL RESTORATION MK51 MK-F OAK RIDGE FPSC MK63 MK-F DH, OAK RIDGE

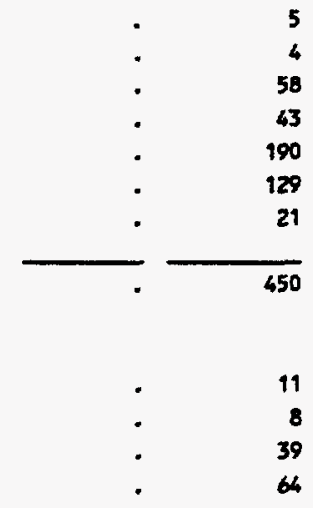


ISOTOPE DEACTIVATION PROGRAM

FISCAL YEAR SUMUARY

$s 1=\mathbf{s 1 0 0 0}$

$07 / 28 / 1995$

Arranged By: MBS / Participant Code

Fiscal Yeer Range 1995 - 2000

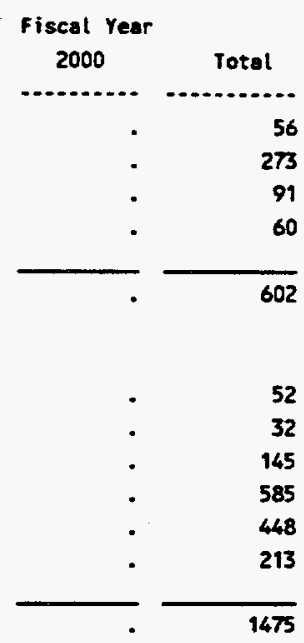

Total CENTER CIRCLE 3030/3034.3118 F

\begin{tabular}{rr}
. & 18 \\
. & 14 \\
. & 81 \\
. & 164 \\
. & 730 \\
. & 438 \\
. & 182 \\
\hline
\end{tabular}

Total BUILDING 3028

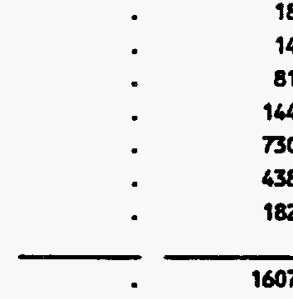

2.10.2.14 BUILDIMG 3047 FACILITY DEACTIY c069 CENTRAL ENGINEERING COS7 ENVIROMHENTAL RESTORATION mK63 mK-F DH, OAK RIDGE TSO1 TECH SUPPORT CONTRACTOR X003 CHEMICAL TECHNOLOGY

X021 PLANT \& EOUIPAENT

X036 OFC OF SAF \& MEALTM PROT

Total BUILDING 3047 FACILITY DEACTIV

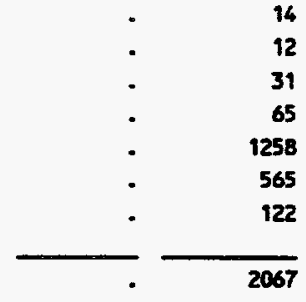

2.10.2.96 EUILDING 3517 FACILITY DEACTIV AEO 1 ARCHITECT-ENGIMEER coso CENTRAL ENGIMEERIMG 
ISOTOPE DEACTIVATION PROGRAN

FISCAL YEAR SUMHARY

$\$ 1=\$ 1000$

$07 / 28 / 1995$

Arronged By: WBS / Participent Code

Fiscal Year Range 1995 - 2000

C087 ENVIRONMENTAL RESTORATION

MKG3 MK-F OH, OAK RIDGE

TSOI TECH SUPPORT CONTRACTOR

X0O3 CHEMICAL TECHMOLOGY

X021 PLANT \& EOUIPNENT

X036 OFC OF SAF \& HEALTH PROT

Total BUILDIMG 3517 FACILITY DEACTIV

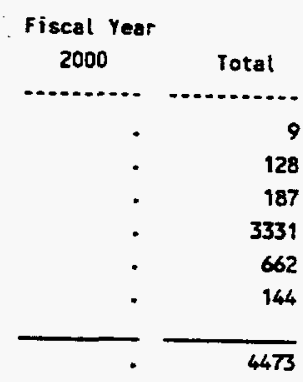

2.10.2.18 BUILOIMG 7025 FACILITY DEACTIV CO69 CENTRAL ENGINEERING

CO87 ENVIRONMENTAL RESTORATION

TSO1 TECH SUPPORT CONTRACTOR

X003 CHEMICAL TECHNOLOGY

X021 PLANT \& EQUIPAENT

X036 OFC OF SAF \& HEALTH PROT

Total BUILDING 7025 FACILITY DEACTIV

2.10.2.20 OTHER FACILITY SUPPORT AHD DEA AEO1 ARCHITECT-ENGINEER

COS4 MUES PROCUREMENT

CO69 CENTRAL EMGIMEERIMG

C087 ENVIRONMENTAL RESTORATIOM

SCOY OFFSITE SUBCONTRACT

XOO3 CHEMICAL TECHMOLOGY

X008 HEALTH SCIENCES RESEARCH

TOtal OTHER FACILITY SUPPORT AND DEA

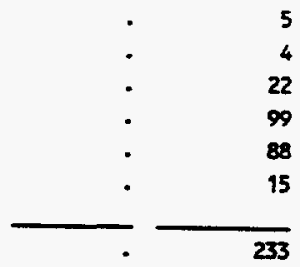

Sub-Total

Overhead

Sub-Total

Cont ingency

Grand Total

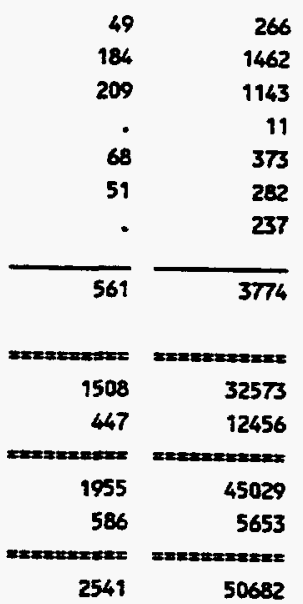




\section{DISTRIBUTION}

1. J. W. Autrey

2. C. A. Bednarz

3. J. B. Berry

4. T. Bonine

5. H. L. Boston

6. W. D. Brickeen

7. R. A. Brown

8. T. W. Burwinkle

9. C. Clark, Jr.

10. R. H. Coe

11. K. Constant

12. A. G. Croff

13-22. R. E. Eversole (10)

23. S. B. Garland

24. K. W. Haff

25. C. T. Higdon

26. J. J. Hooyman

27. L. L. Kaiser

28. E. A. Krispin

29. A. J. Kuhaida

30. D. W. Malkemus

31. R. C. Mason

32. T. J. Newsom
33-34. P. T. Owen

35. L. D. Owens

36. R. S. Owens

38. R. D. Patton

39. P. A. Pehlman

40. H. X. Phillips

41. D. W. Ramey

42. P. D. Ramsey

43. G. Q. Rennich

44. P. Rittenhouse

45. S. M. Robinson

46. P. A. Schrandt

47. B. H. Singletary

48. S. D. Van Hoesen

49. A. B. Walker

50. M. L. Whitehead

51. P. S. Wood

52. ORNL ER Doc. Manage. Center

53. Central ER Doc. Manage. Center

54. Laboratory Records Dept.

55. ORNL Patent Section

56. Central Research Library

57. Office of Assistant Manager for Energy Research and Development, DOE Oak Ridge Operations Office, P.O. Box 2001, Oak Ridge, TN 37831-8600

58-59. Office of Scientific and Technical Information, P.O. Box 62, Oak Ridge, TN 37831

60. V. F. Boston, DOE Oak Ridge Operations Office, P.O. Box 2001, Oak Ridge, TN 378318541

61. C. S. Gist, DOE Oak Ridge Operations Office, P.O. Box 2001, Oak Ridge, TN 37831-8541

62. C. T. Williams, DOE Oak Ridge Operations Office, P.O. Box 2001, Oak Ridge, TN 378318541 